
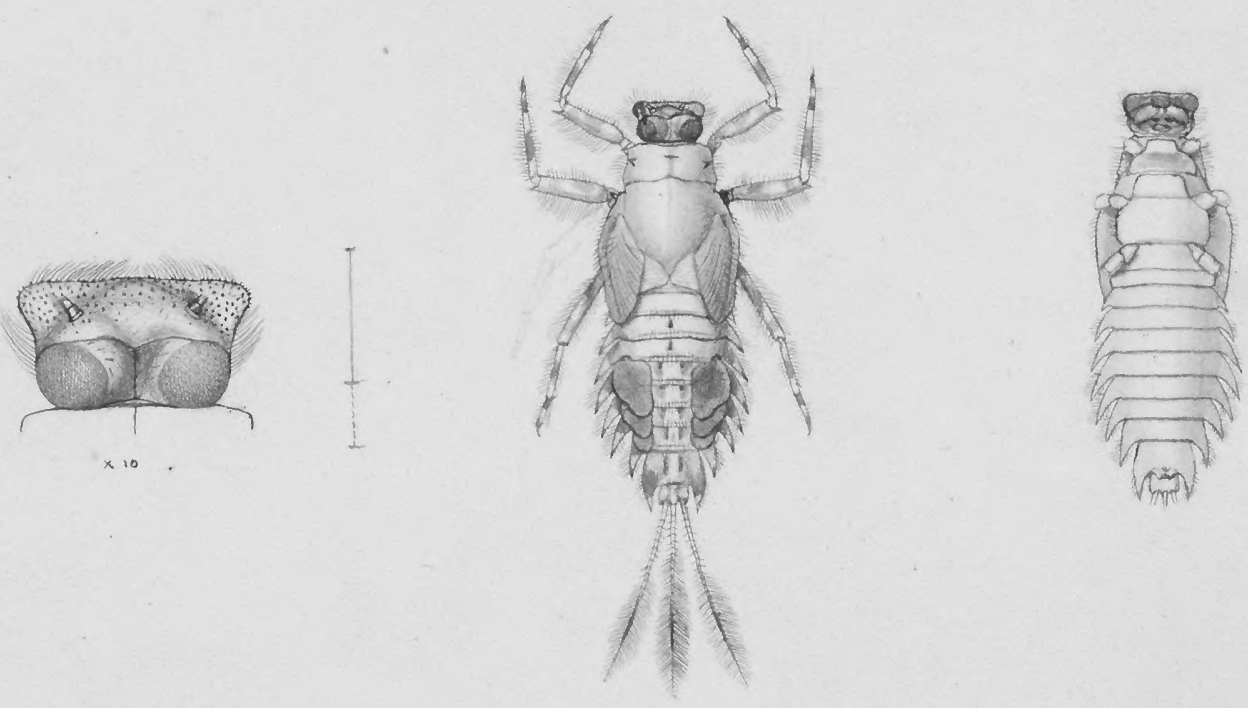


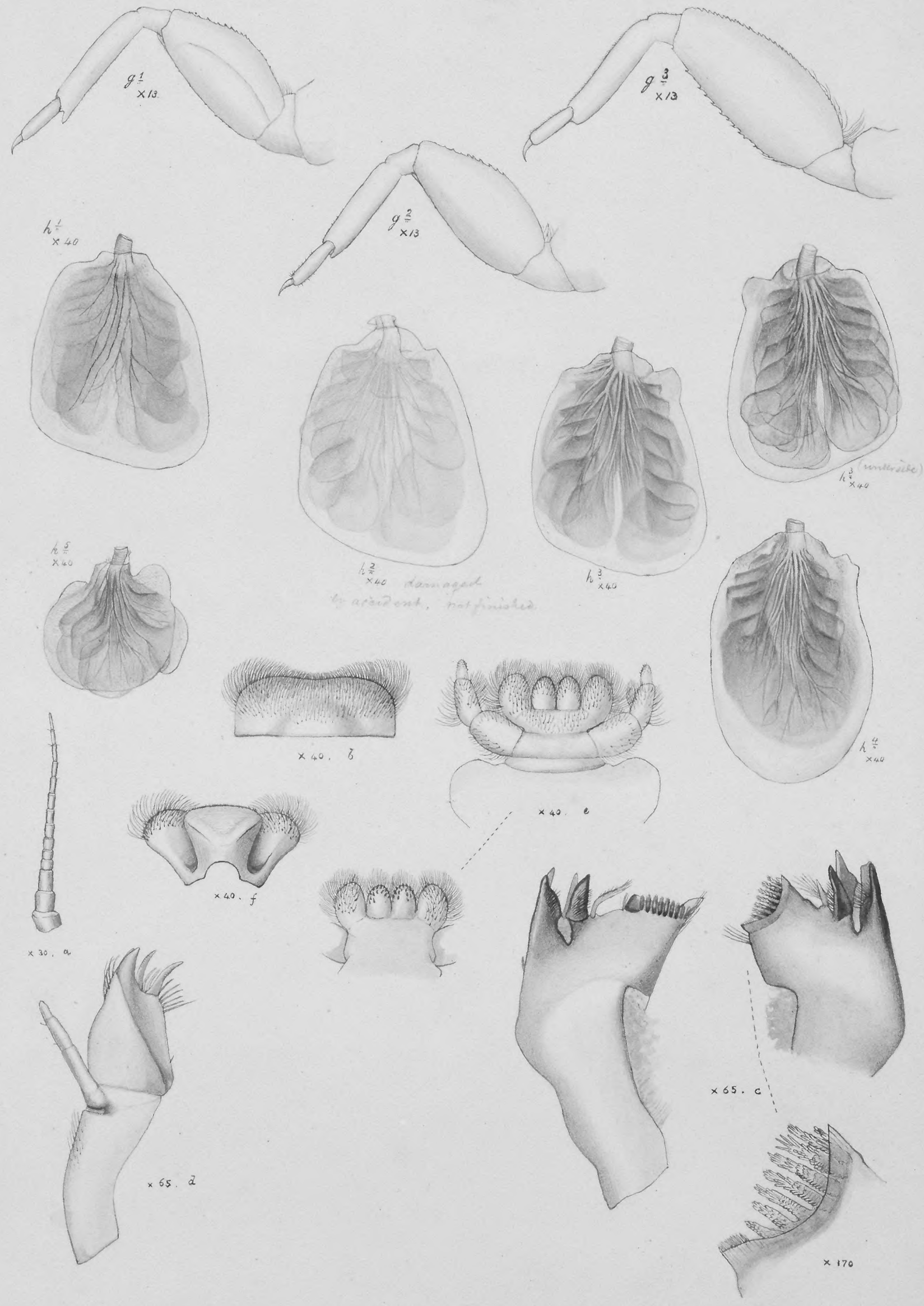



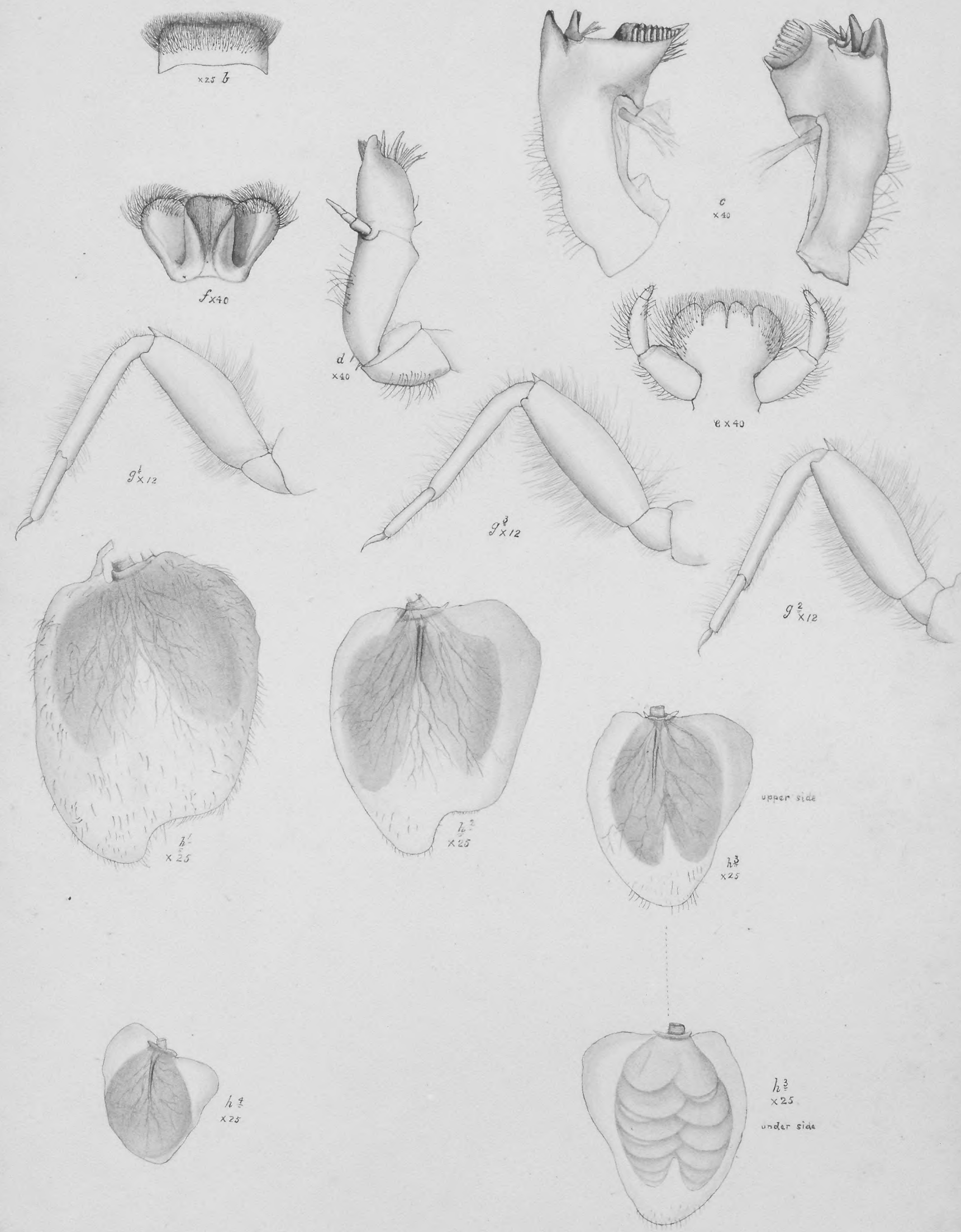


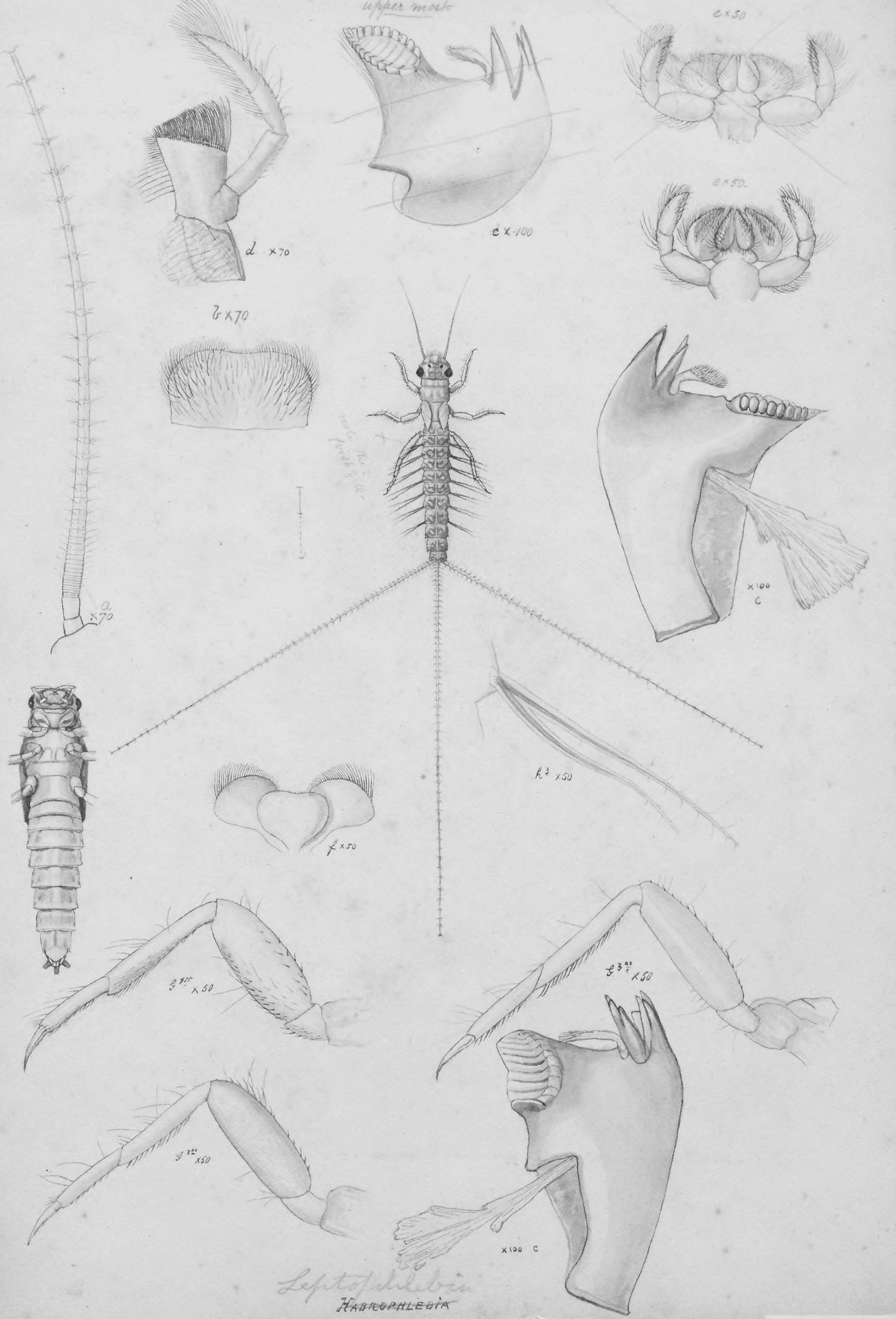




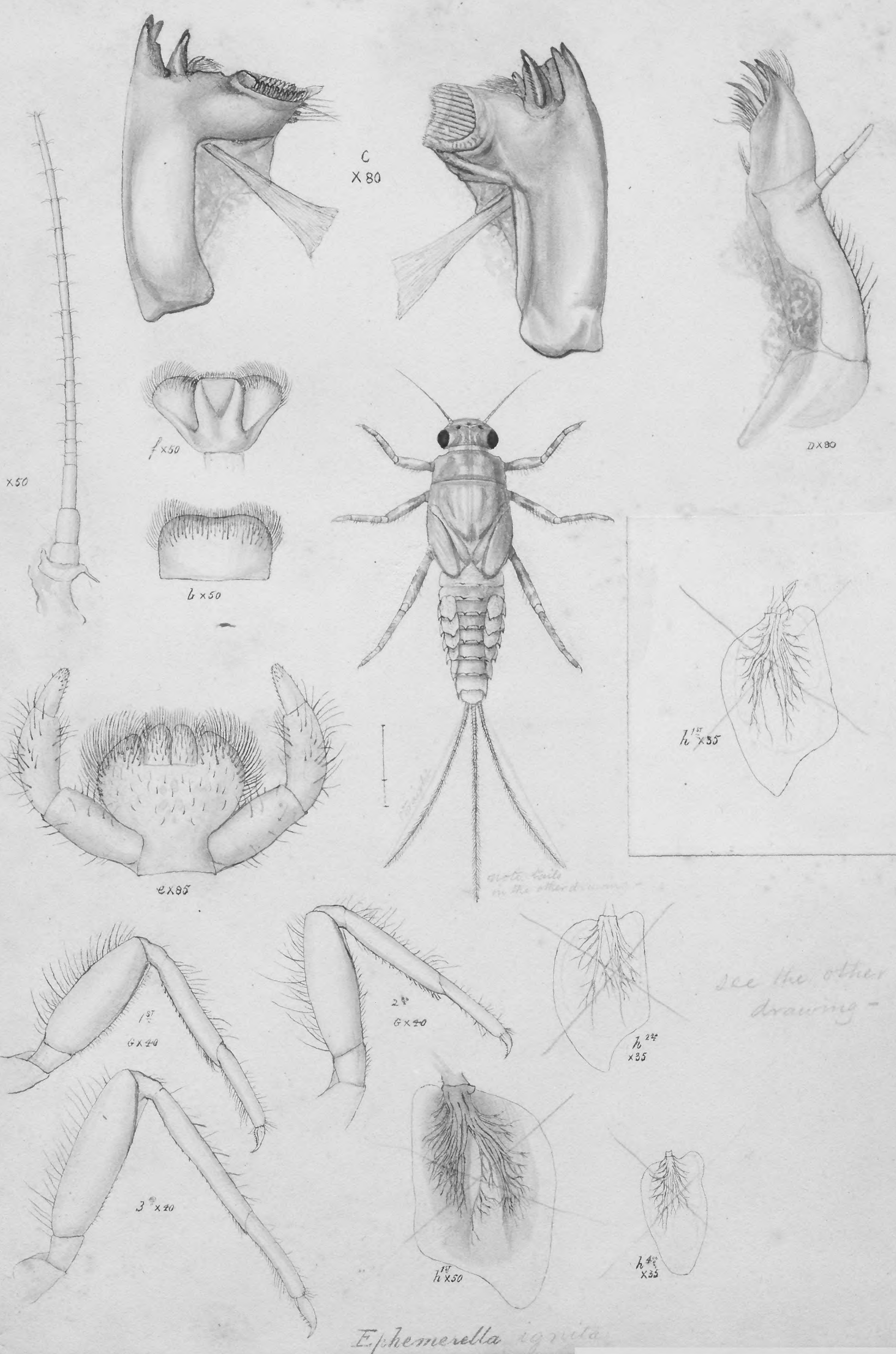



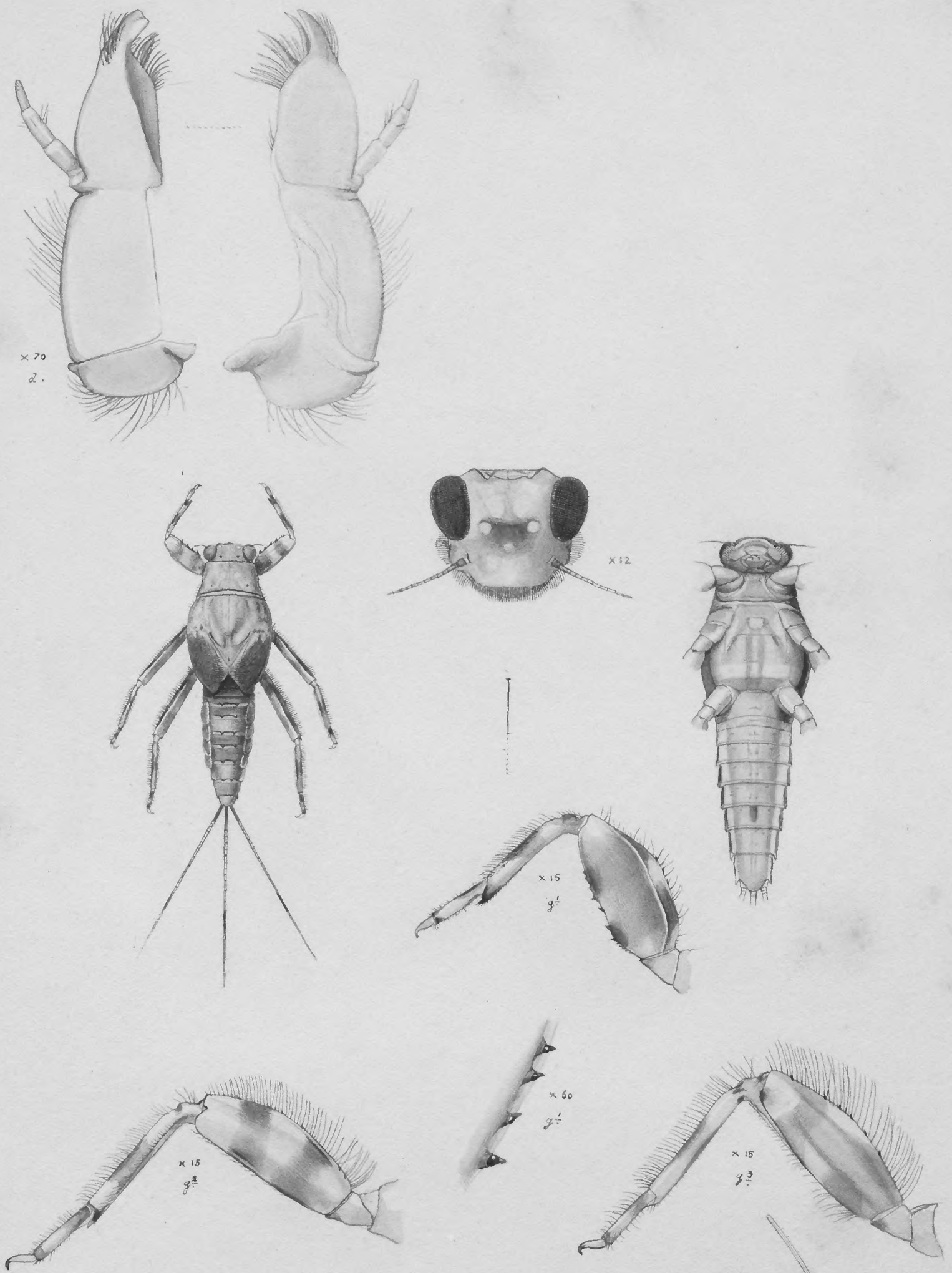

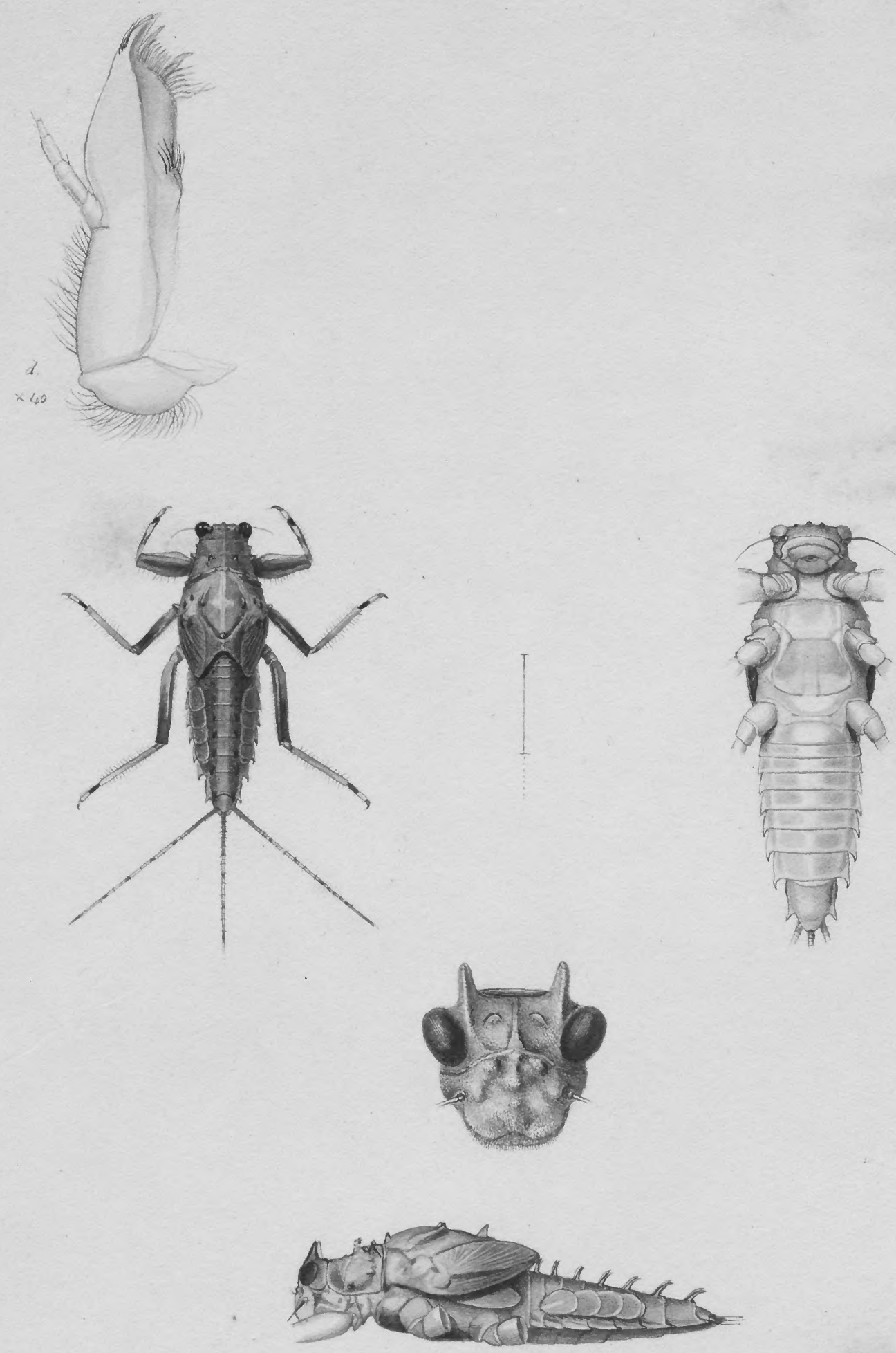

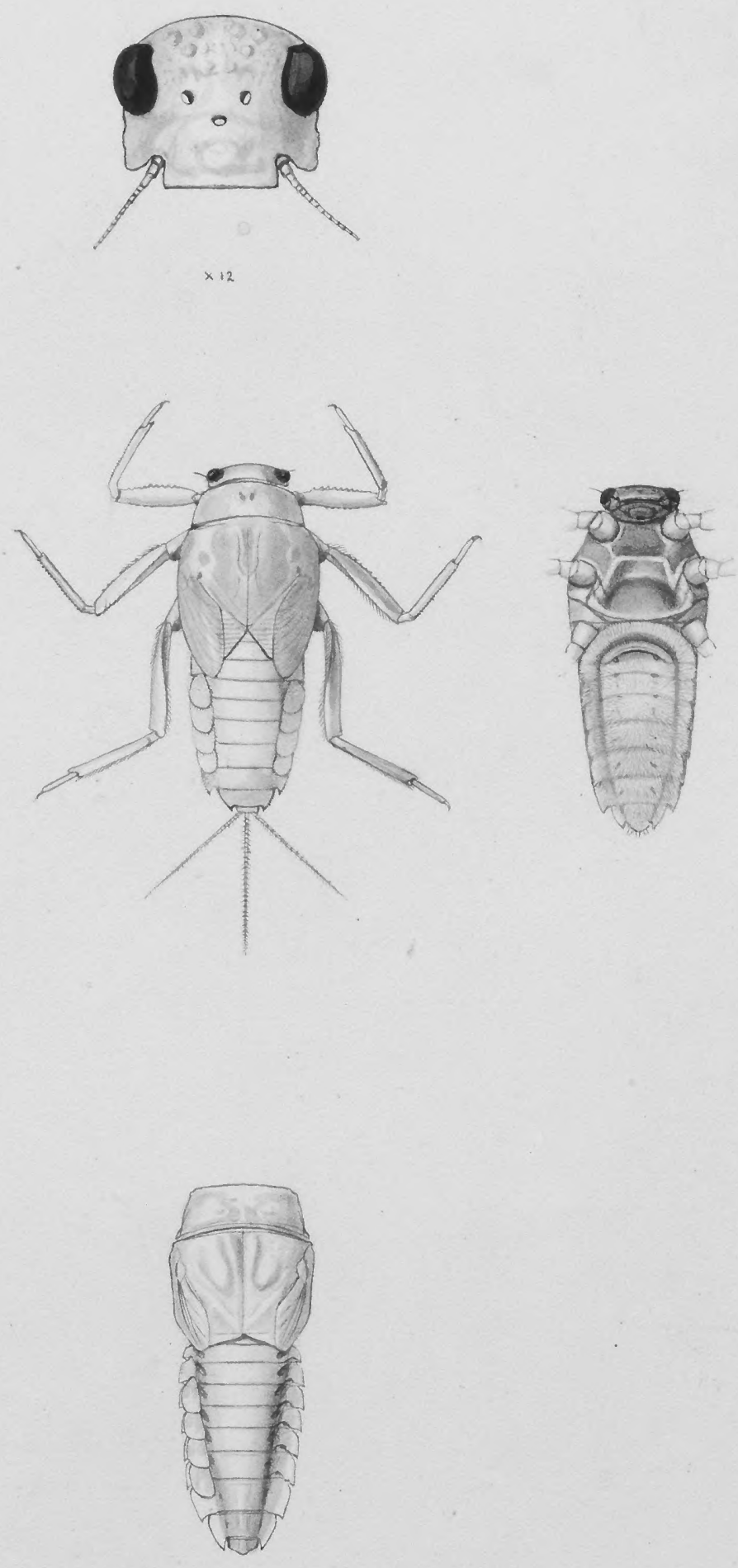

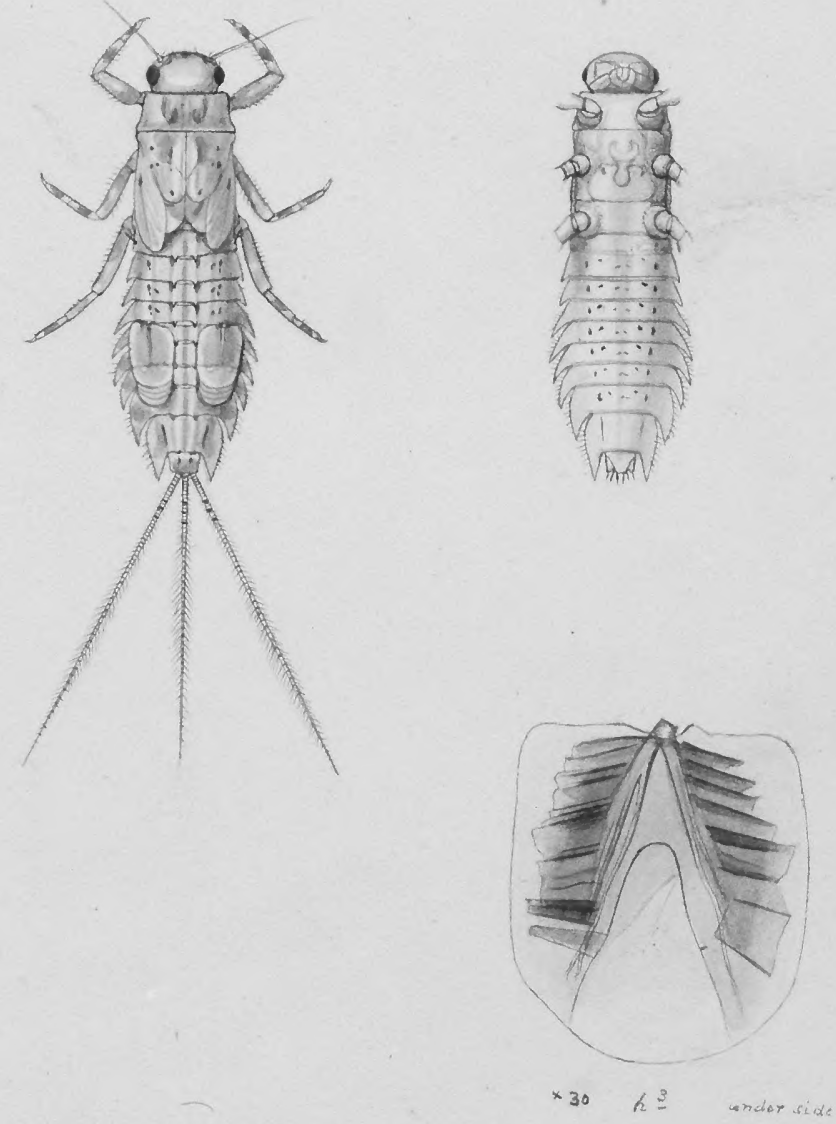

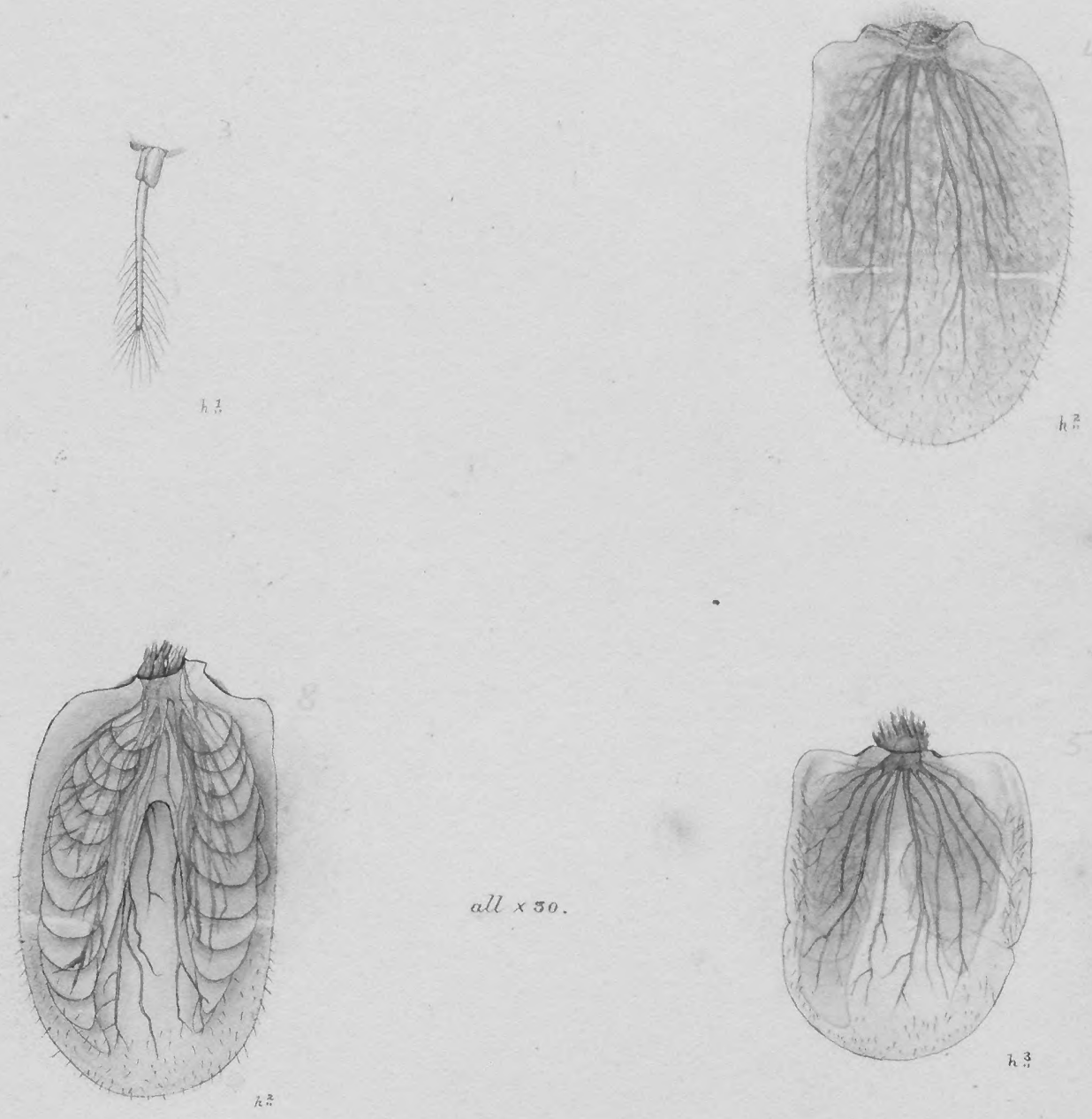

underside
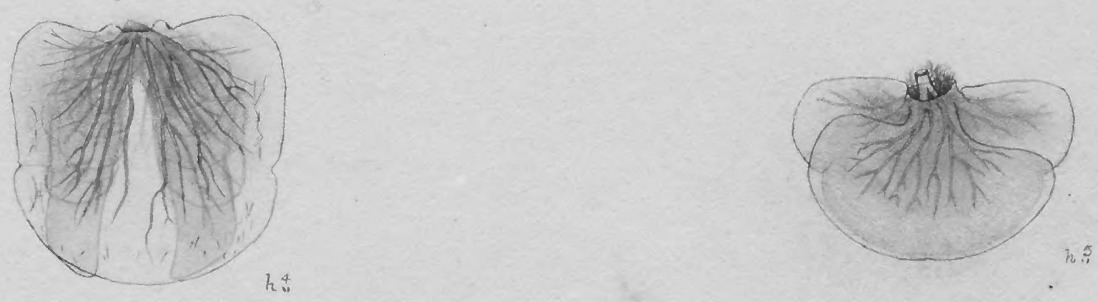

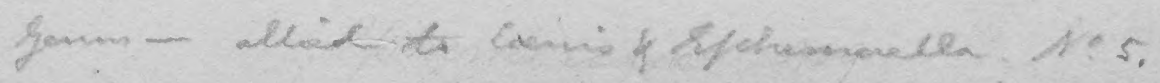




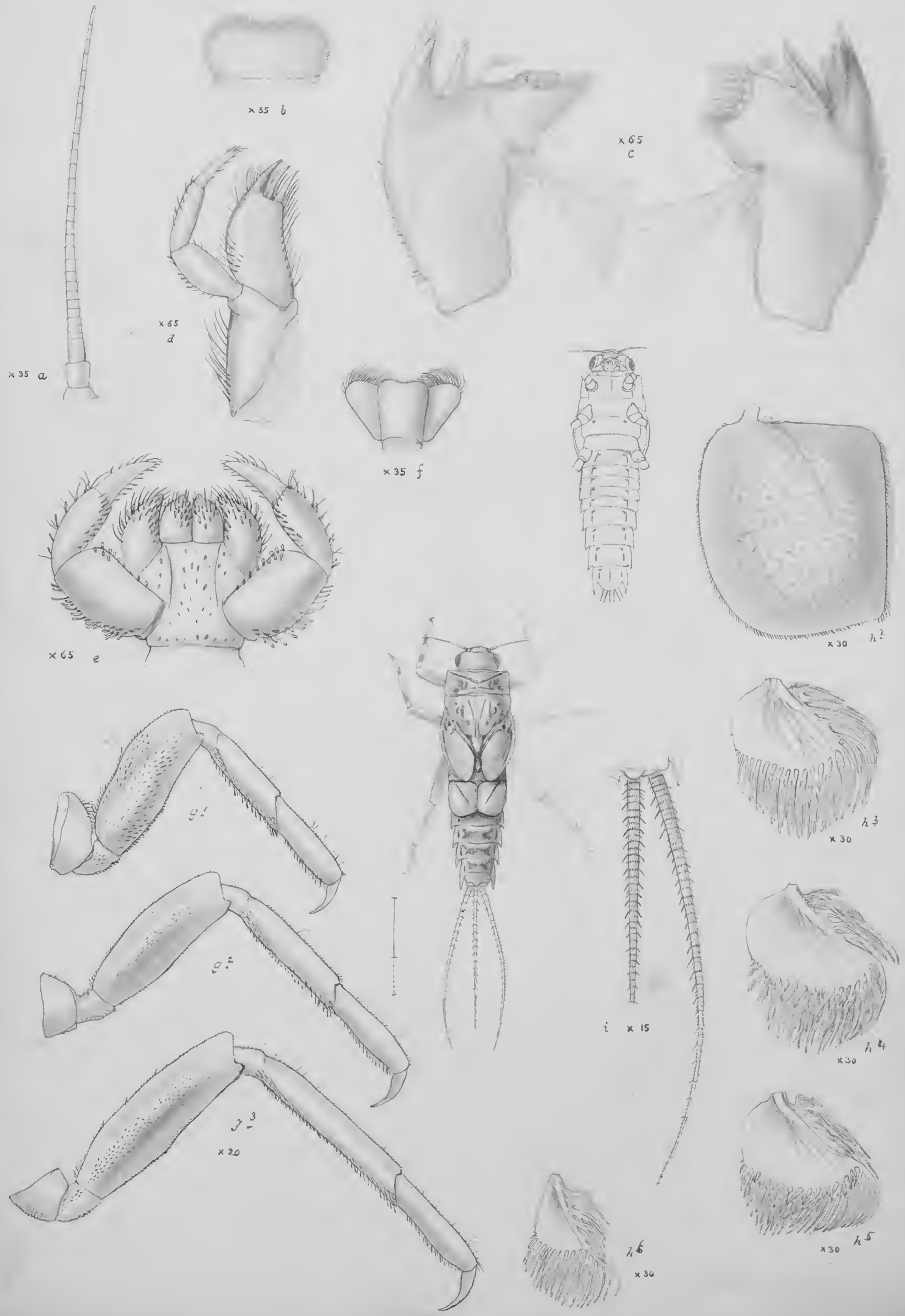



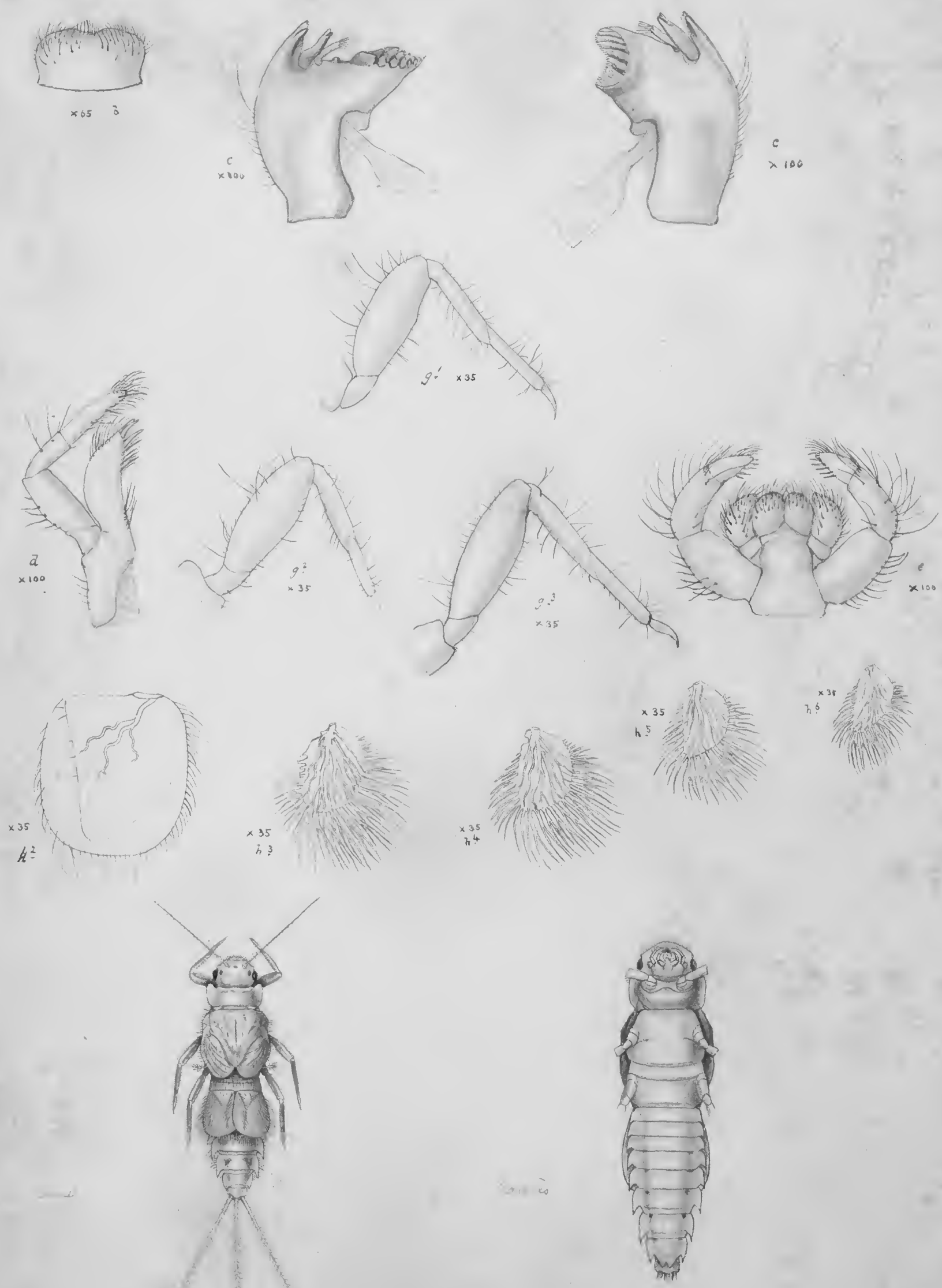


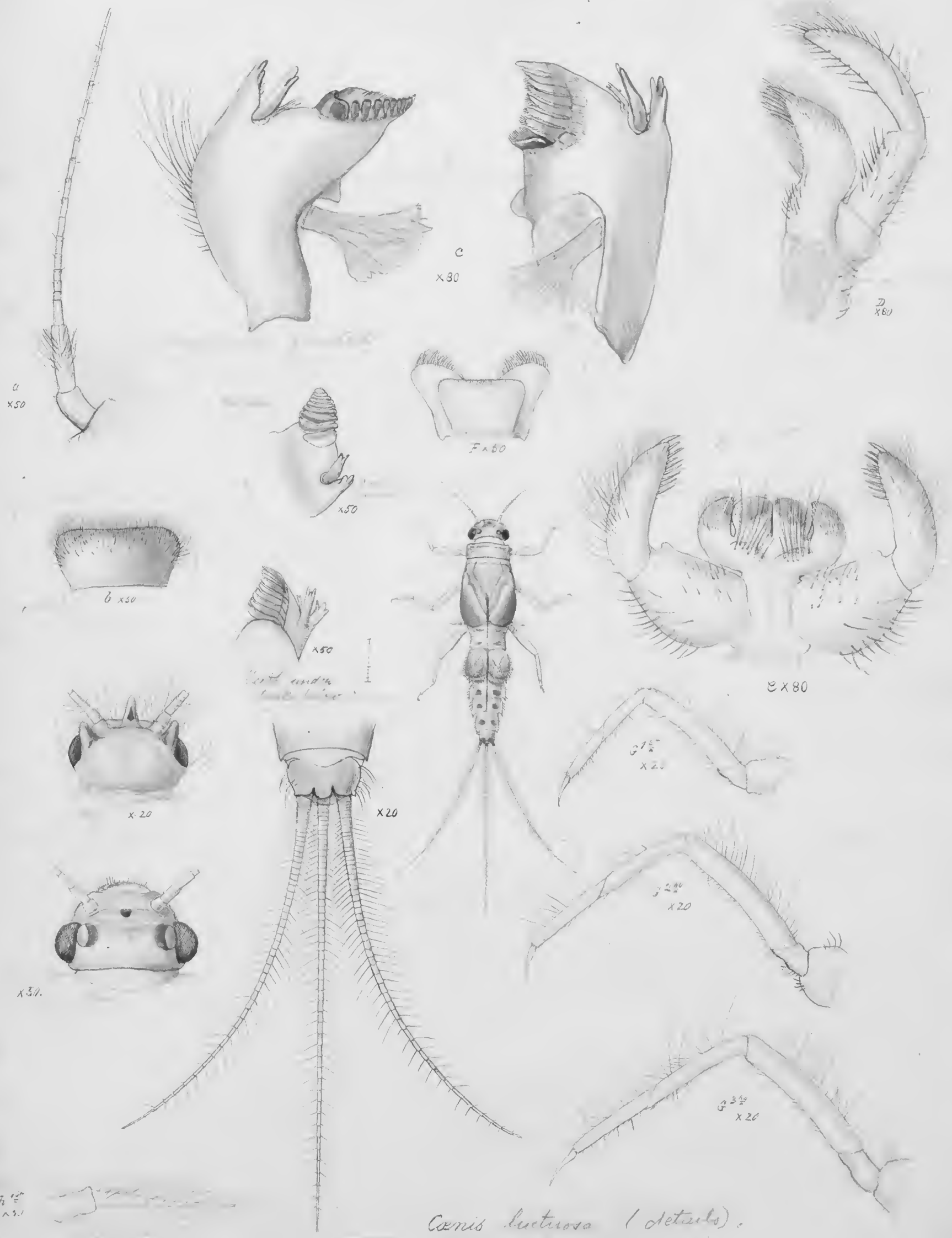



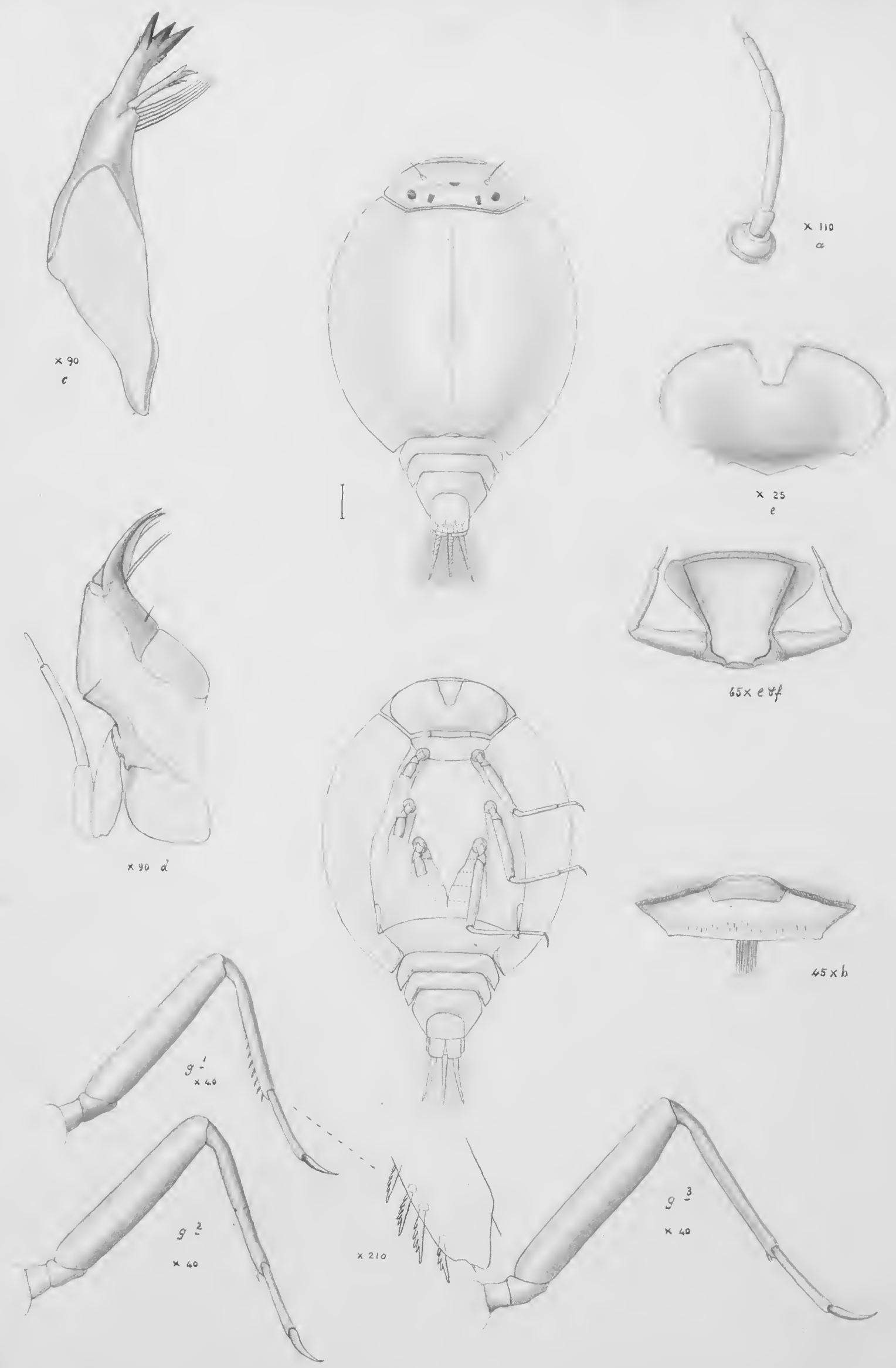

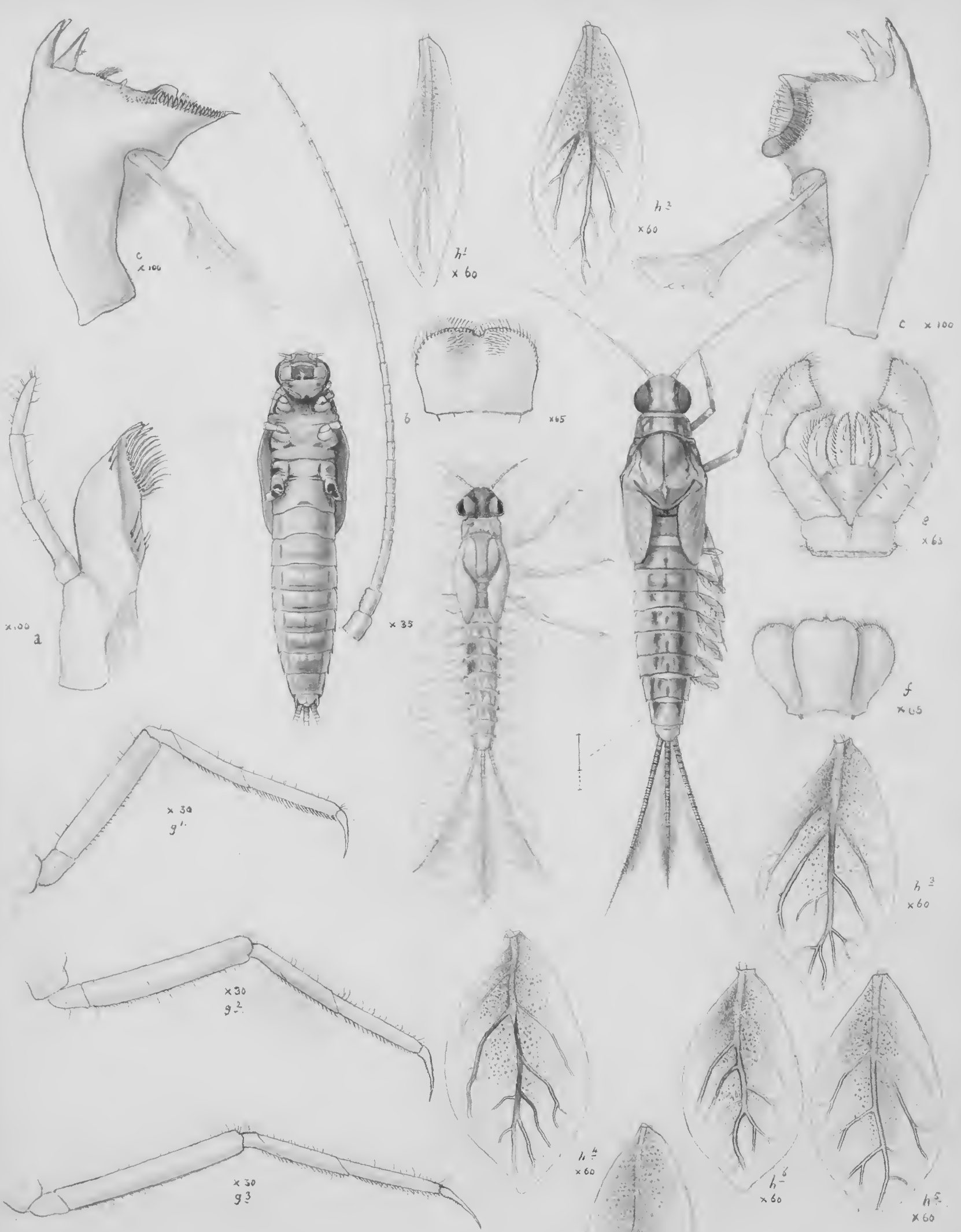


$$
\text { d: }
$$




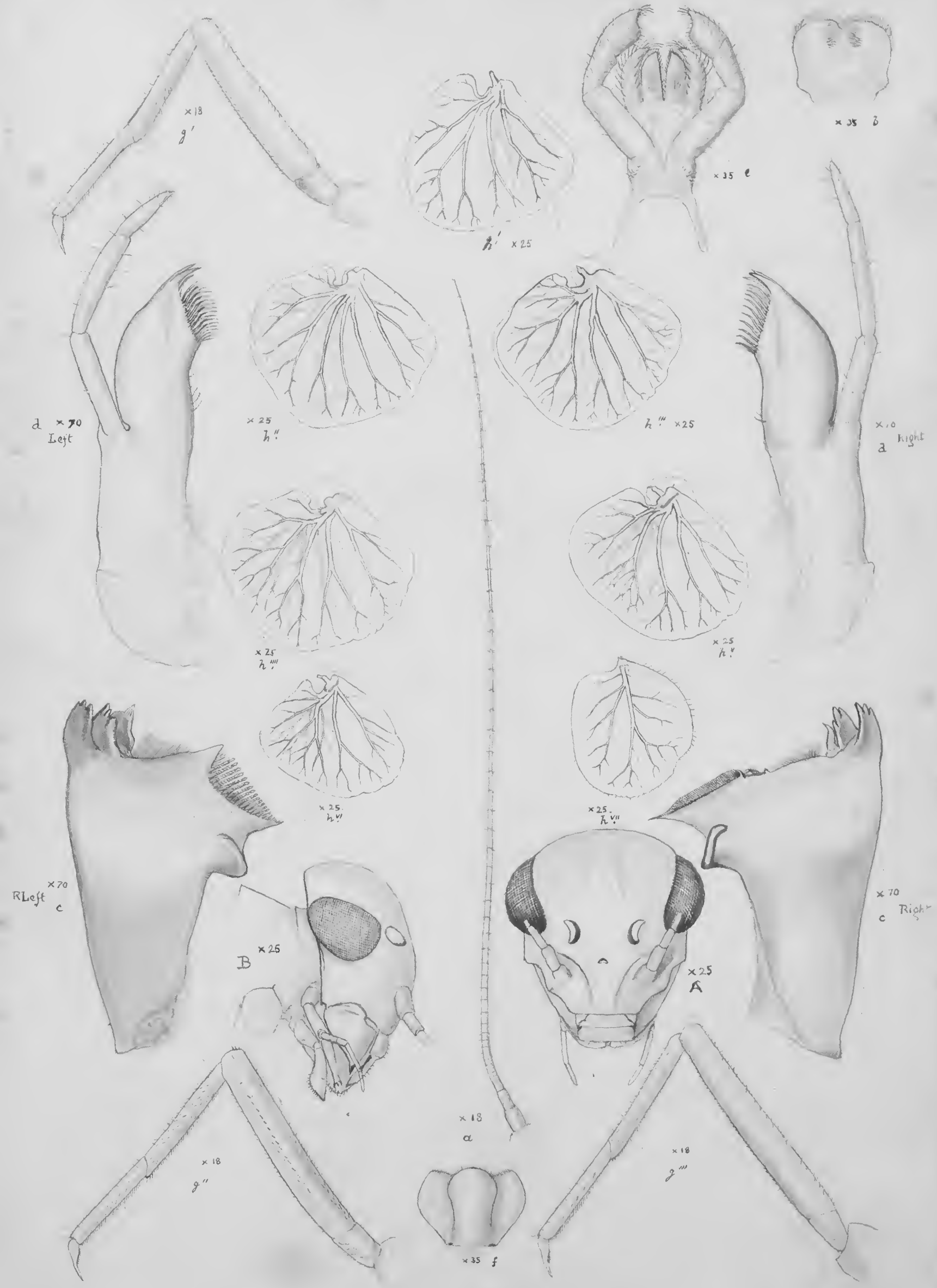



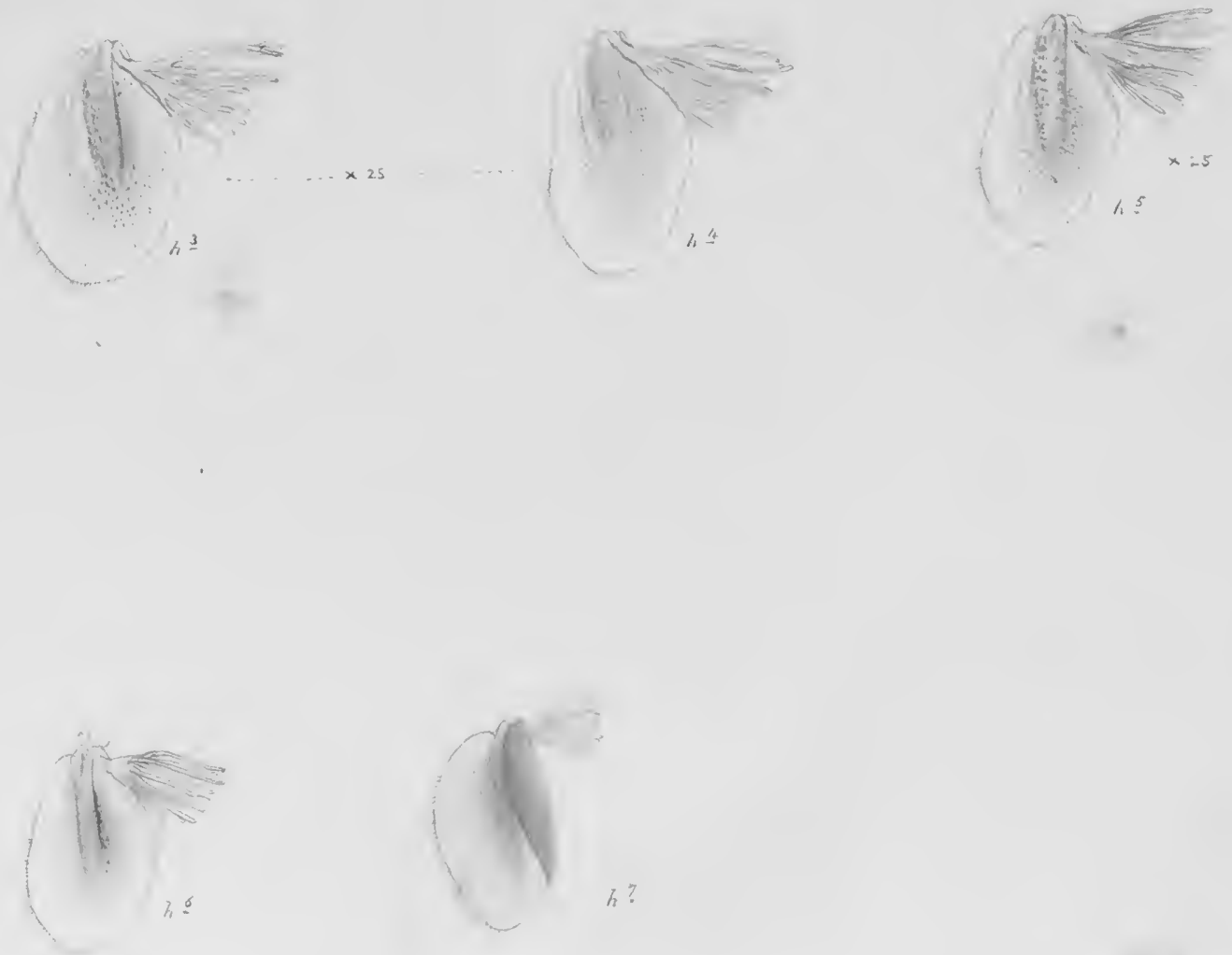


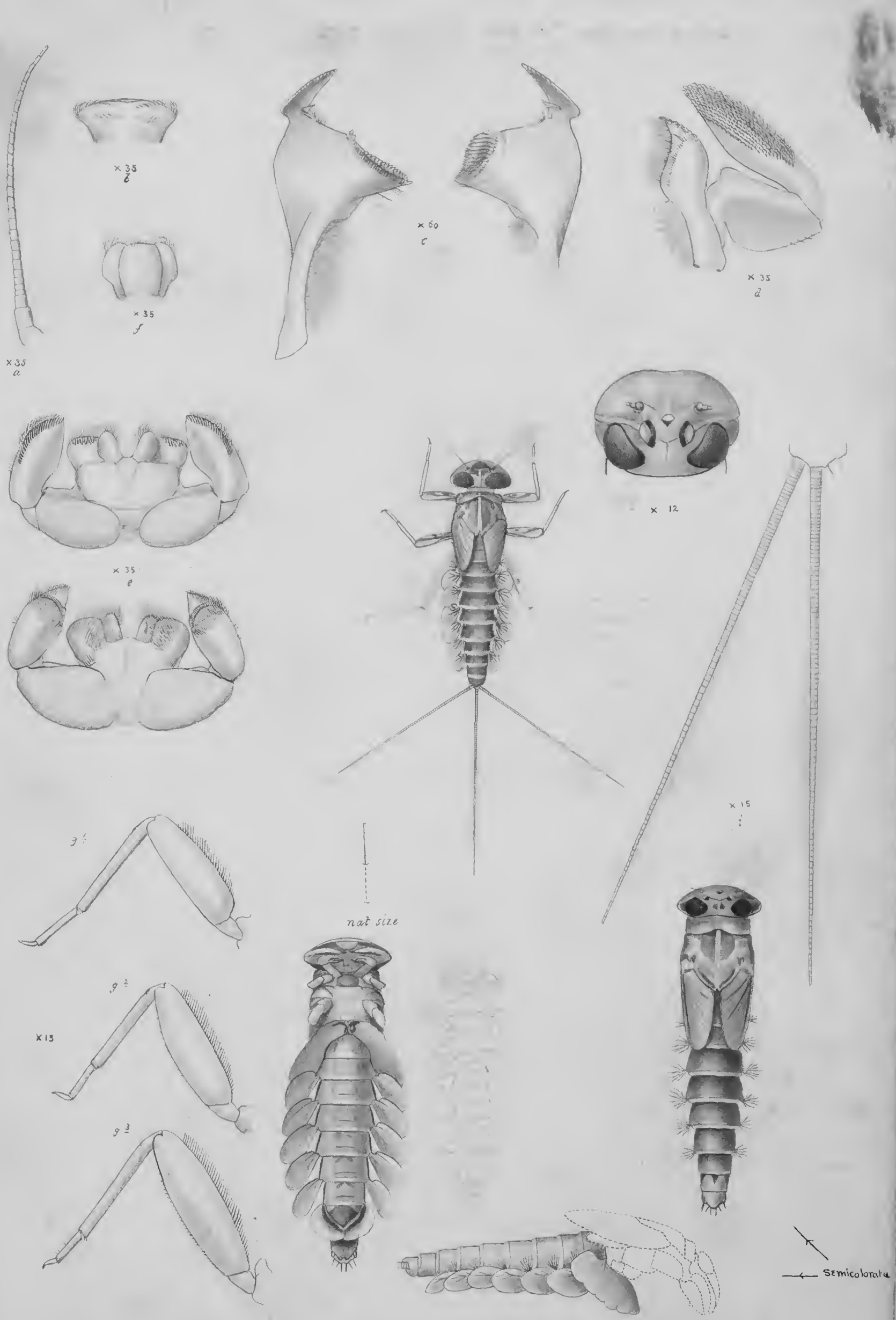

Rhithrogena autantiaca 


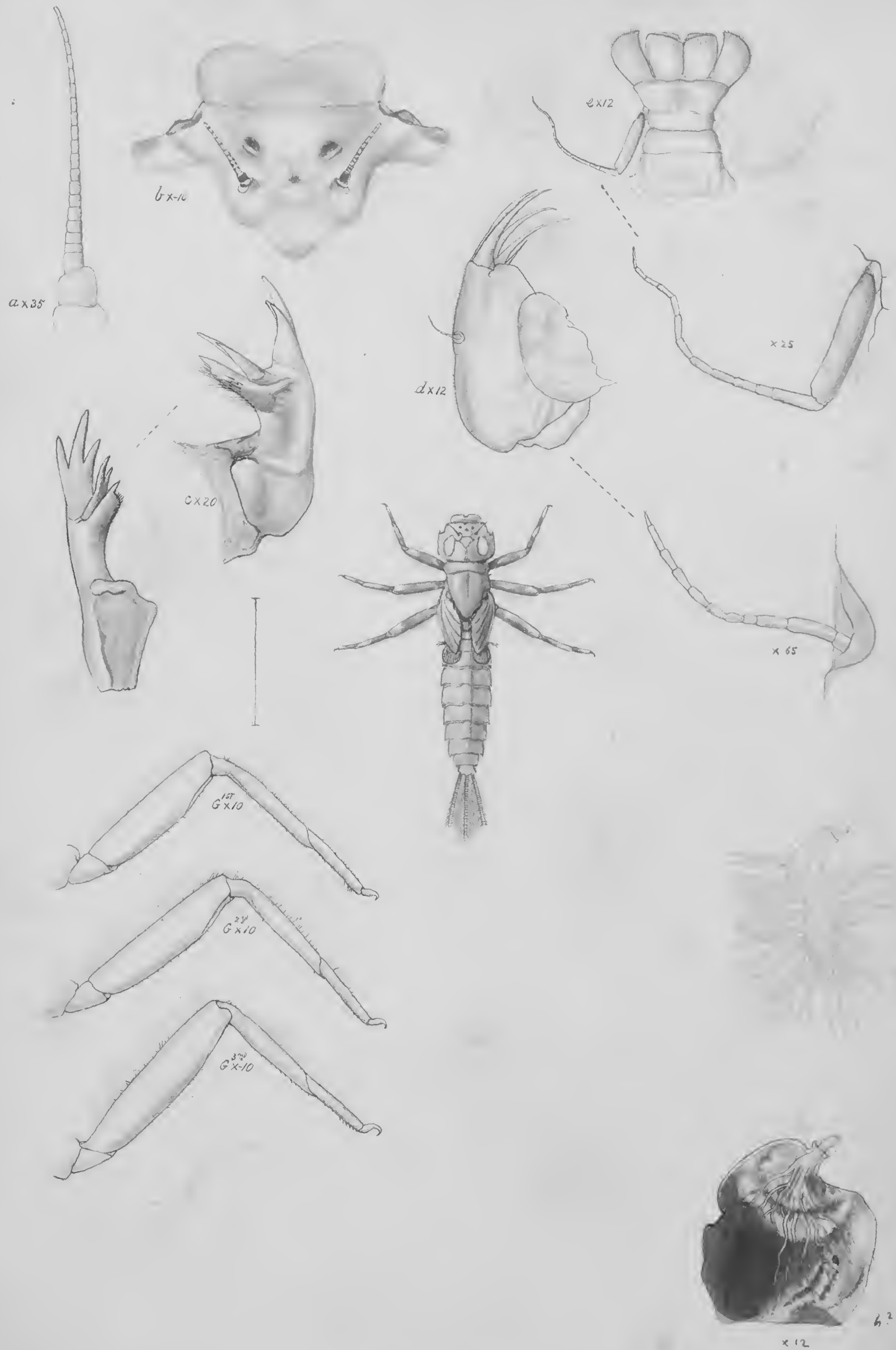




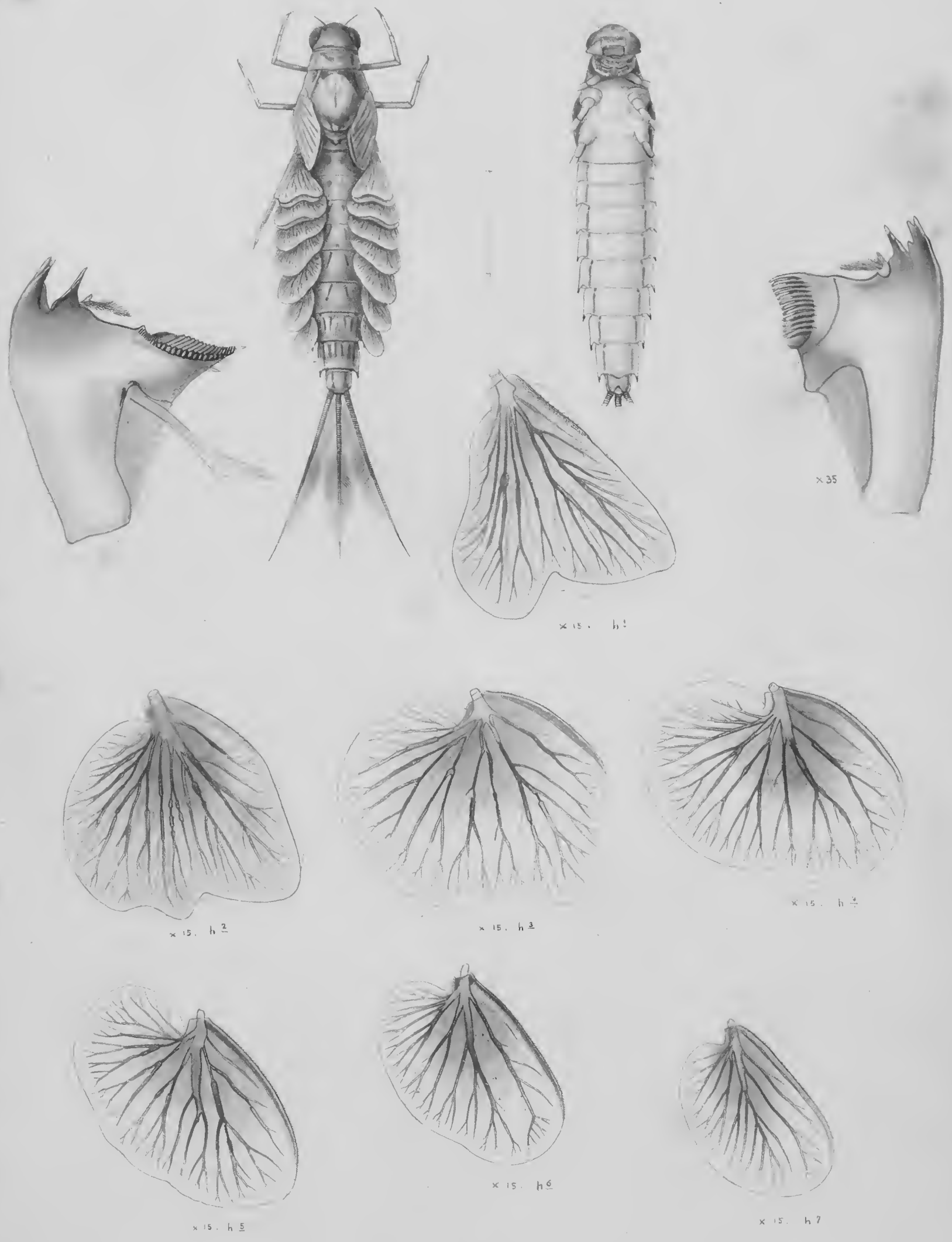




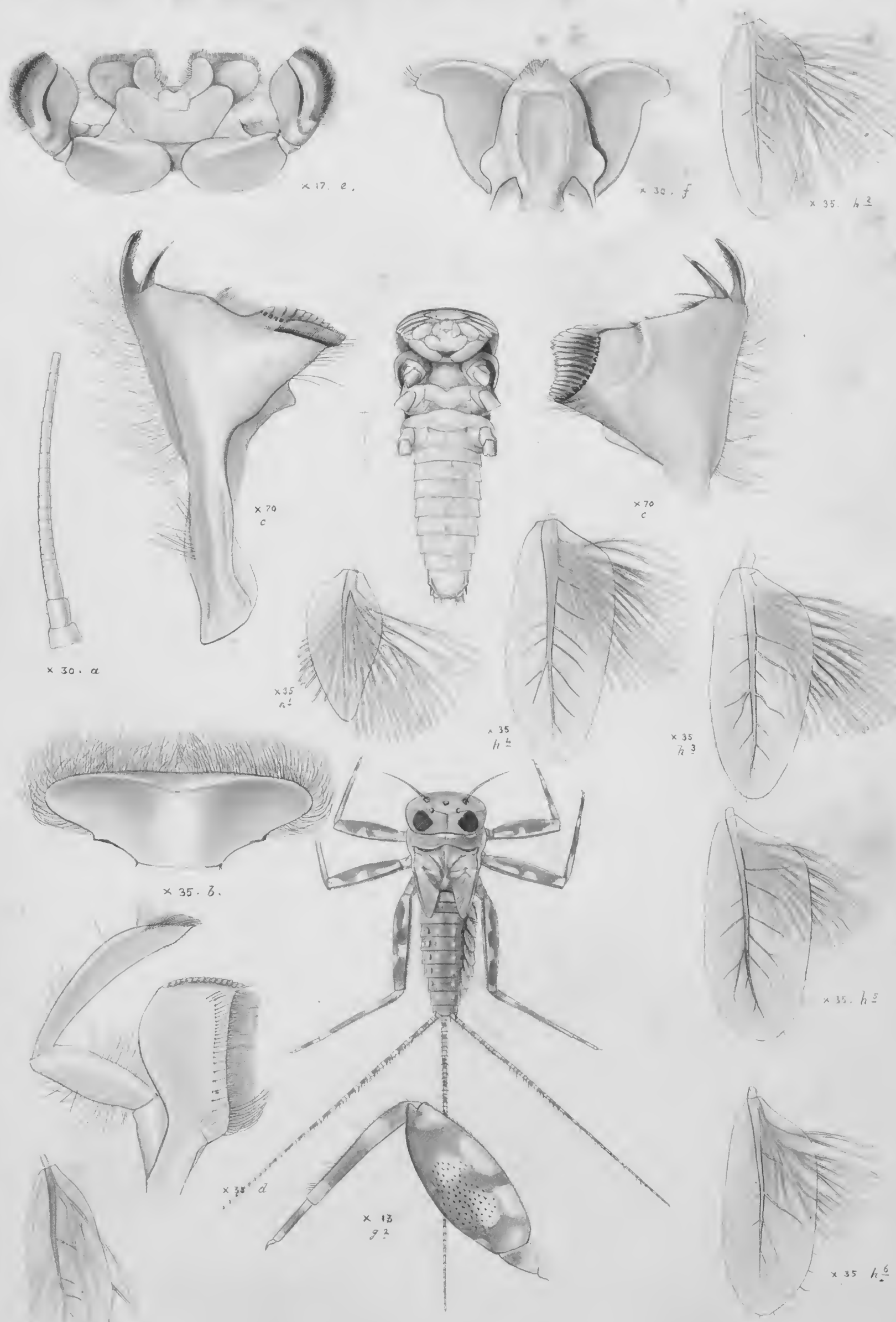

Ecdyurus sp. 

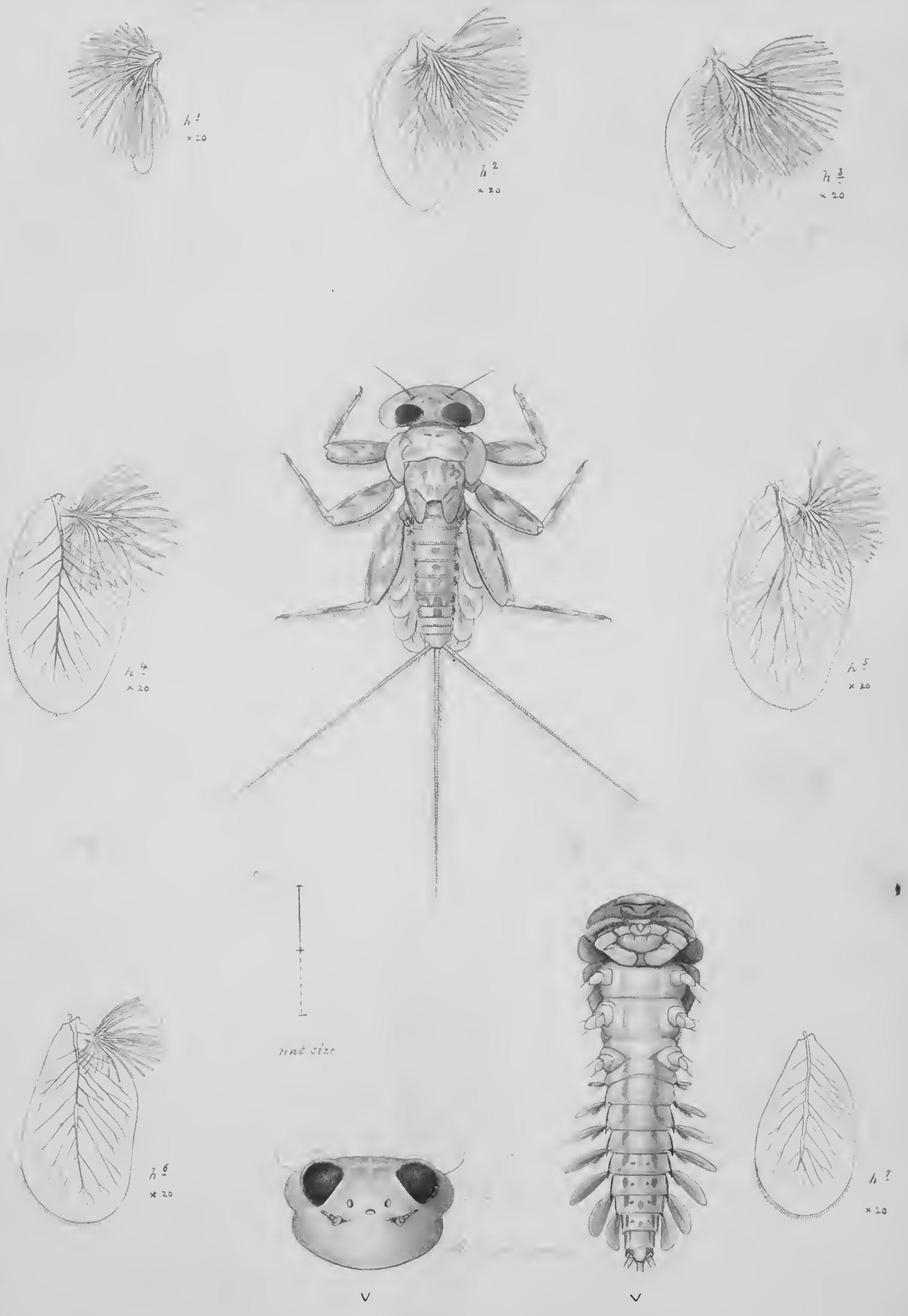


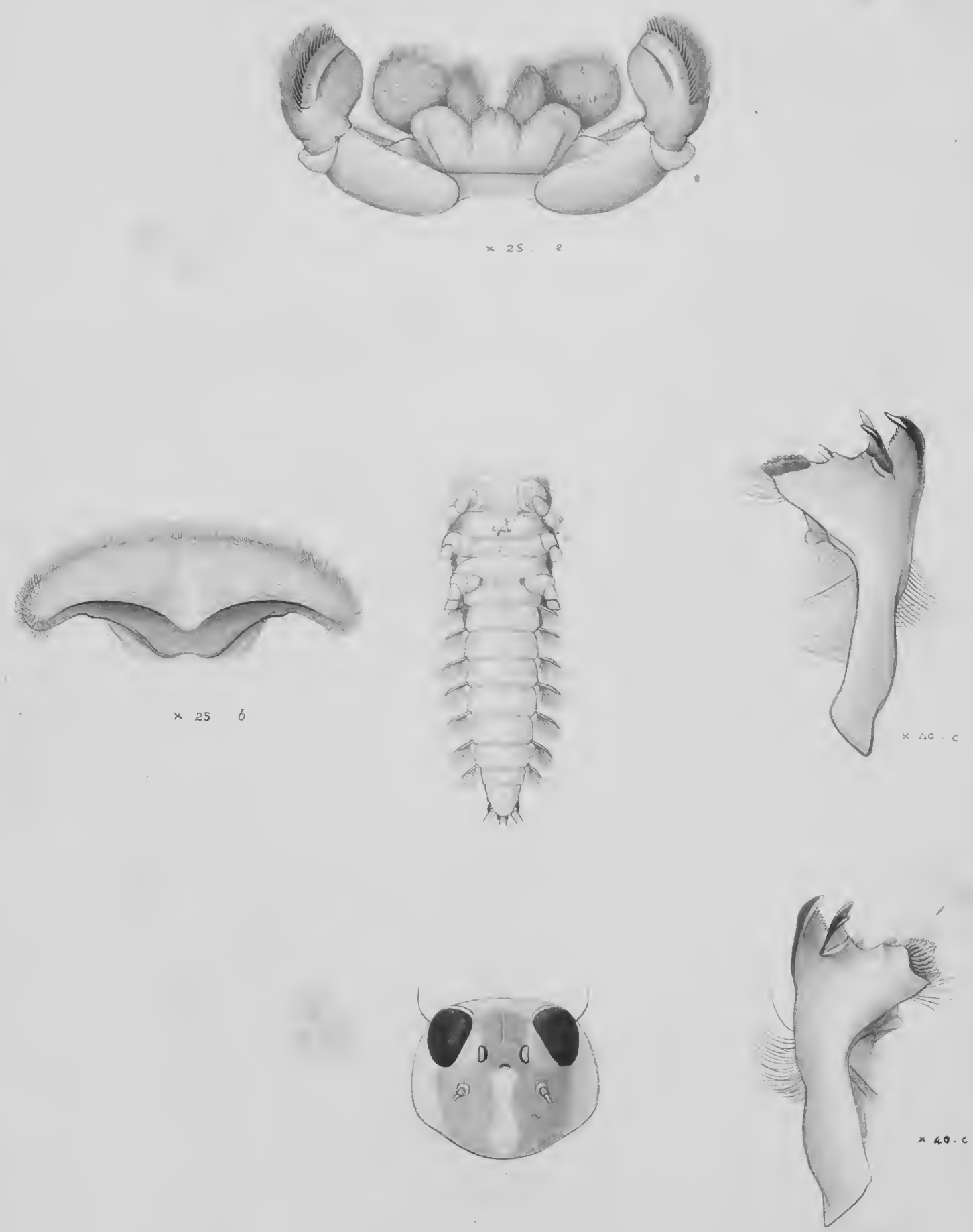


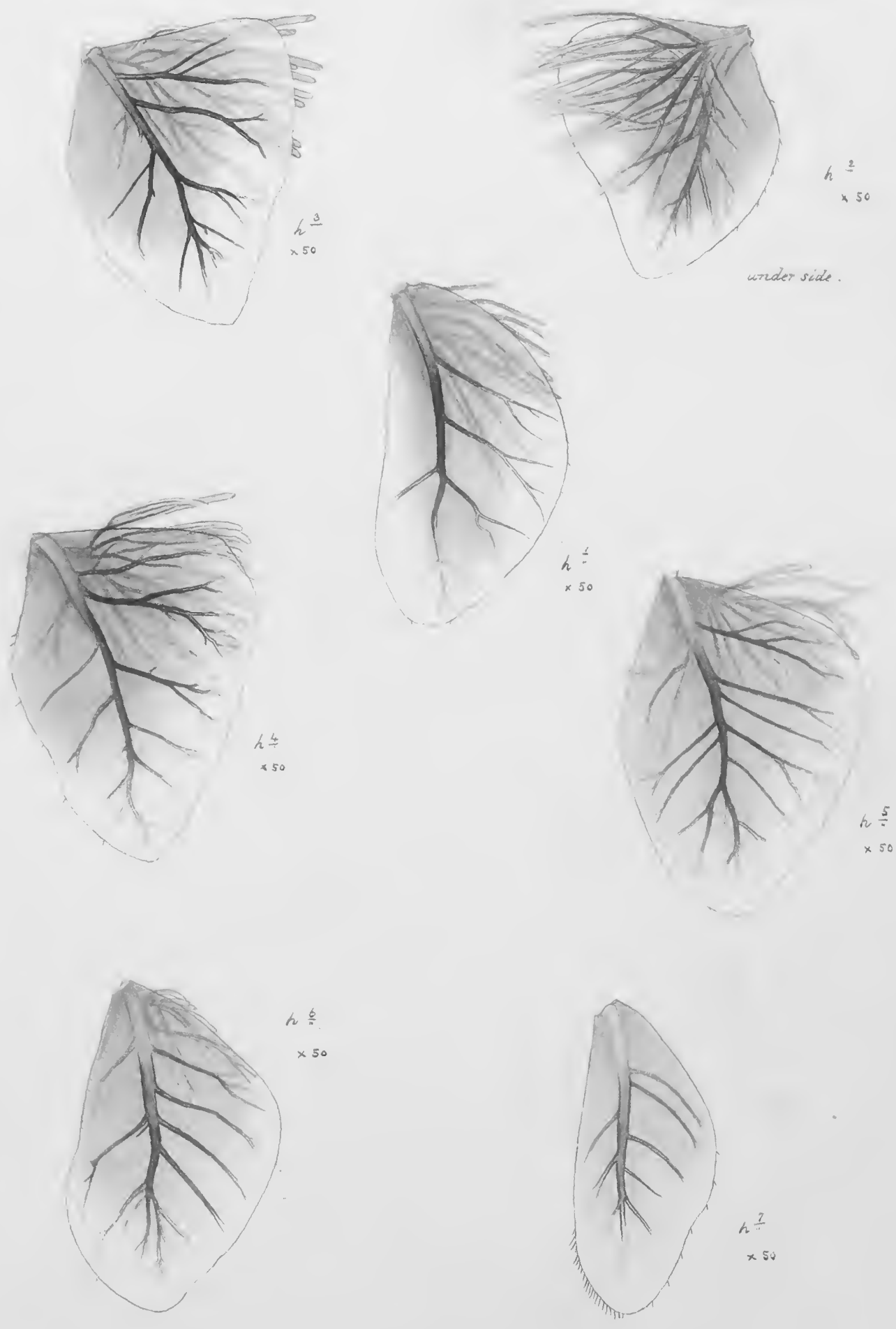

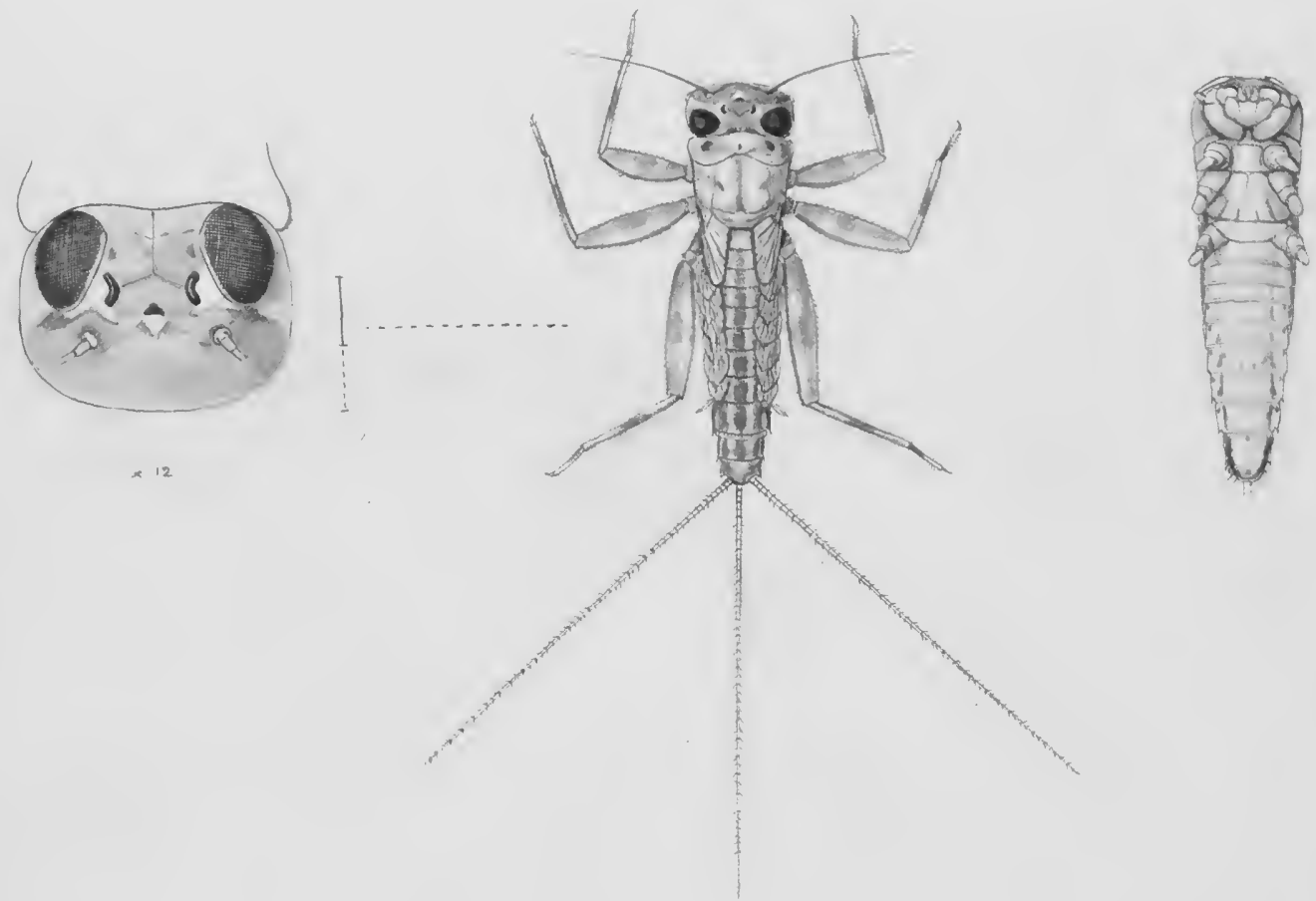

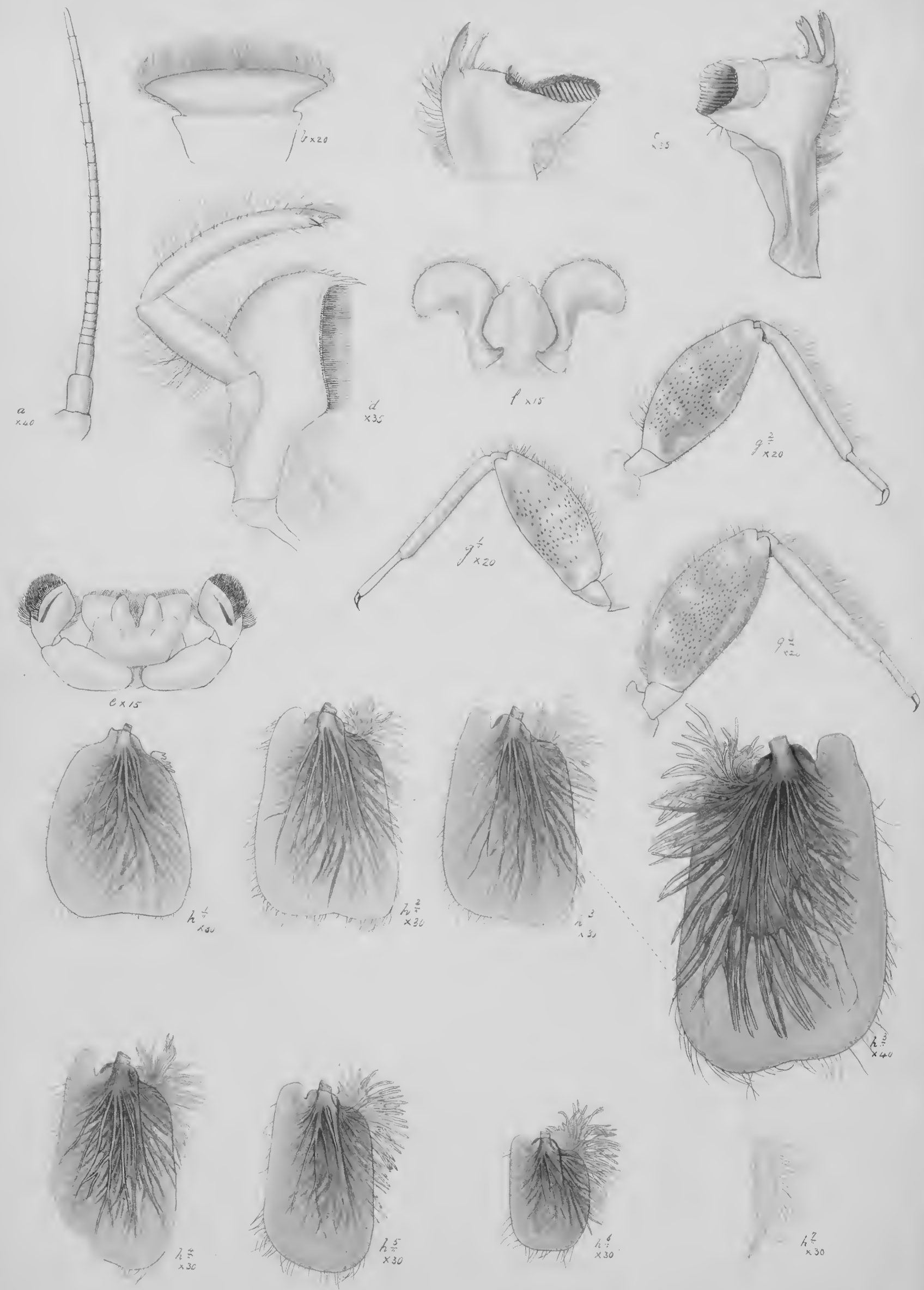

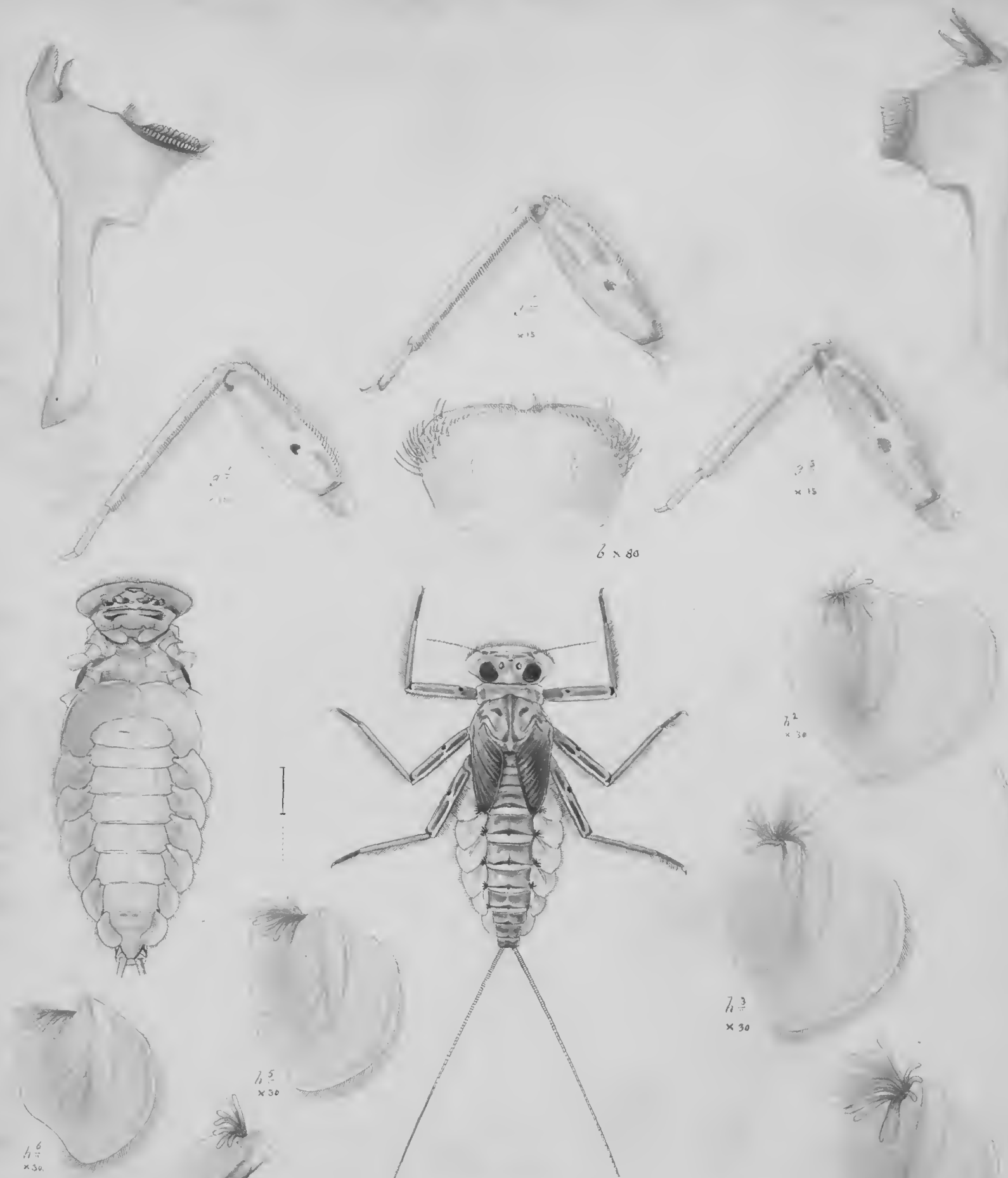

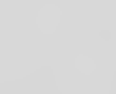

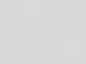

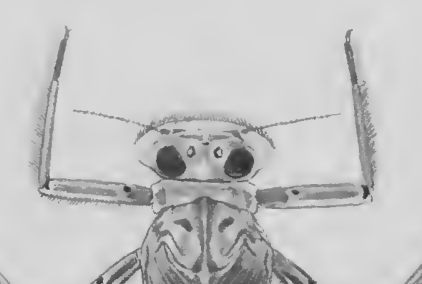




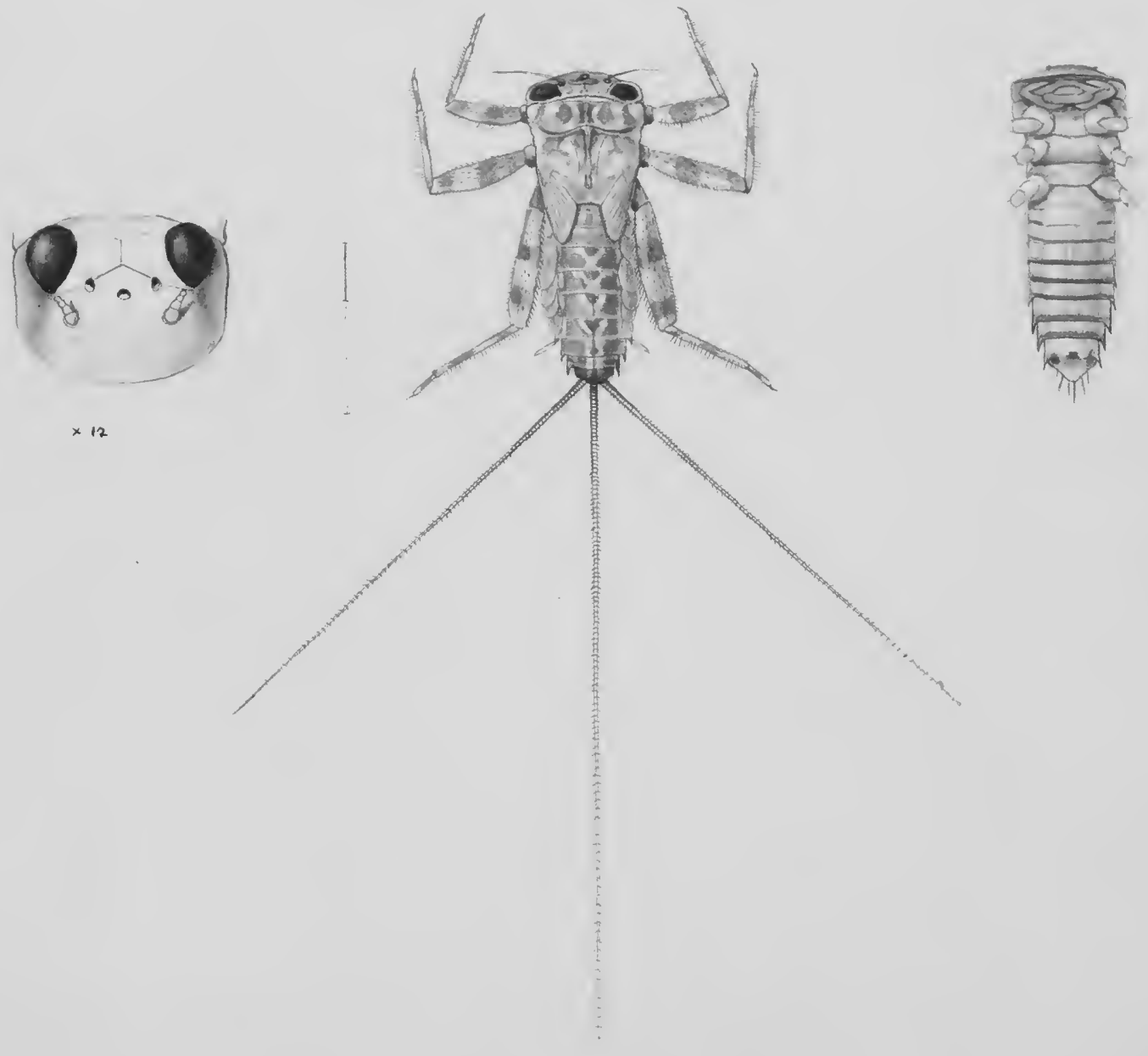

$n a m z \mid \varepsilon s s$ (Nymph - N.America) 


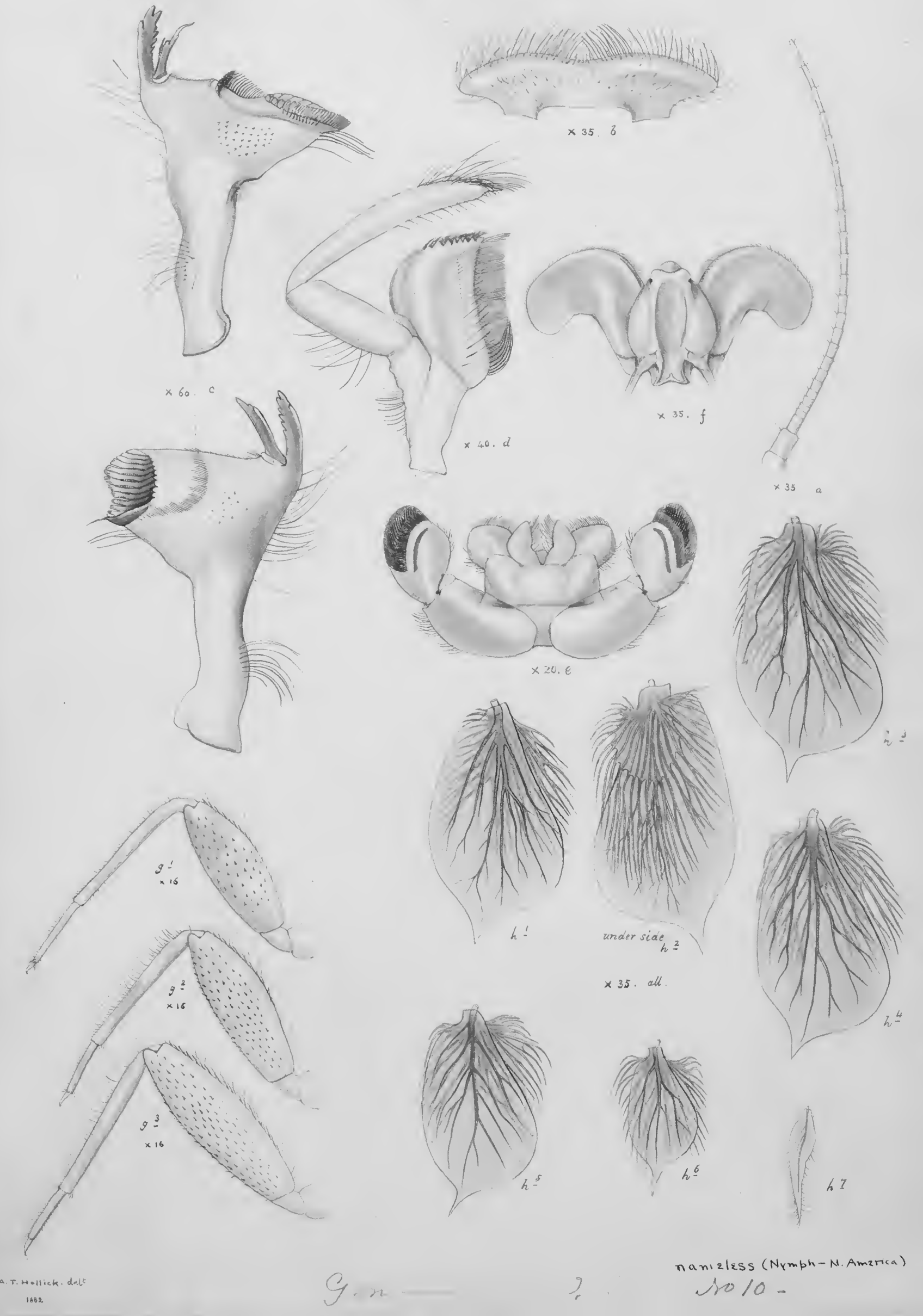



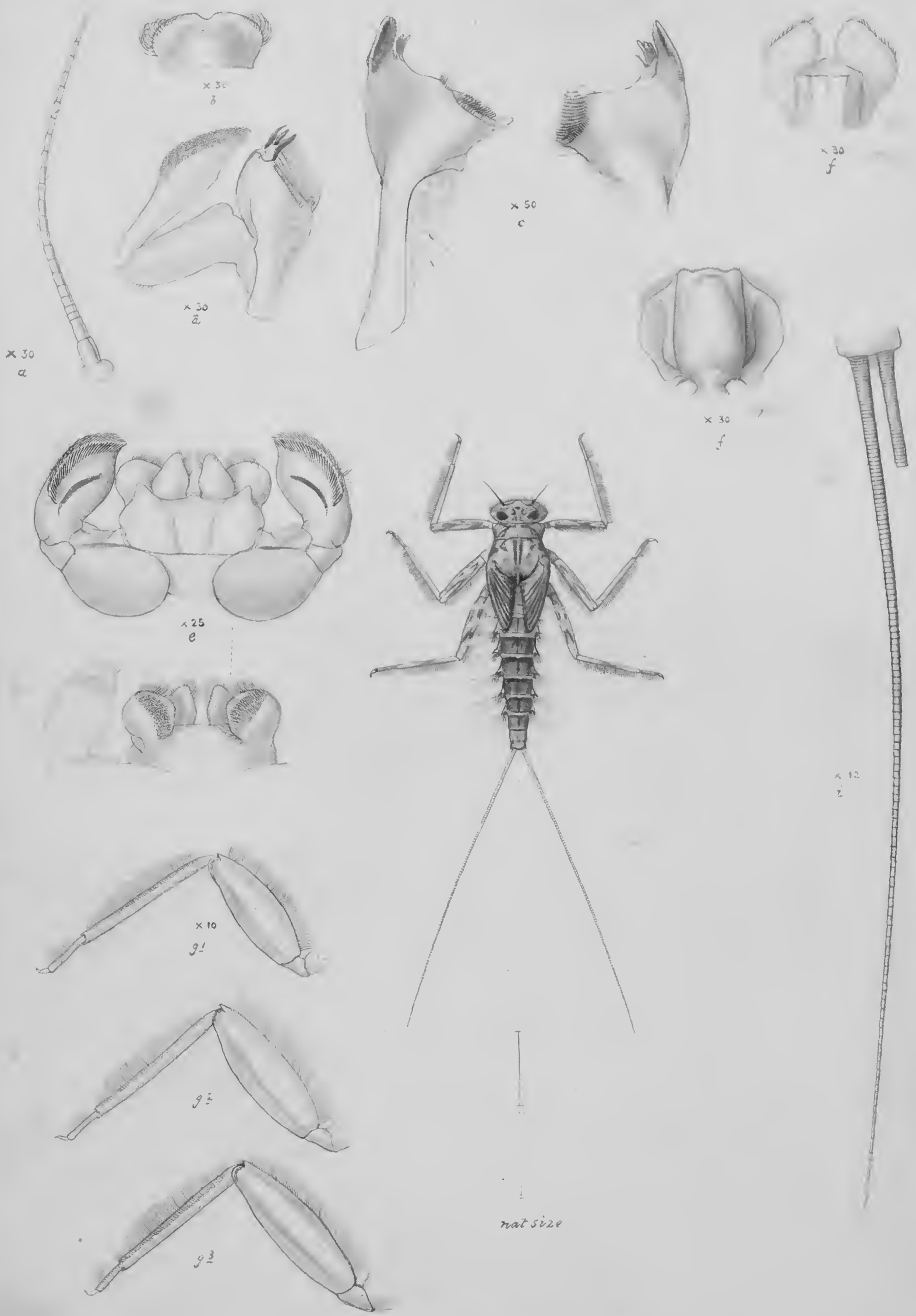

nat size 


$$
11
$$




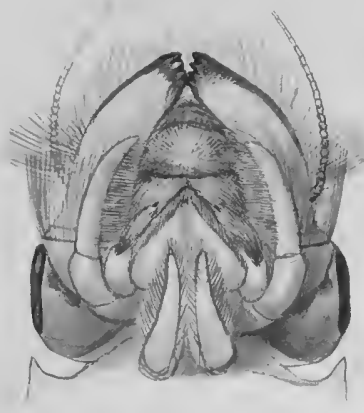



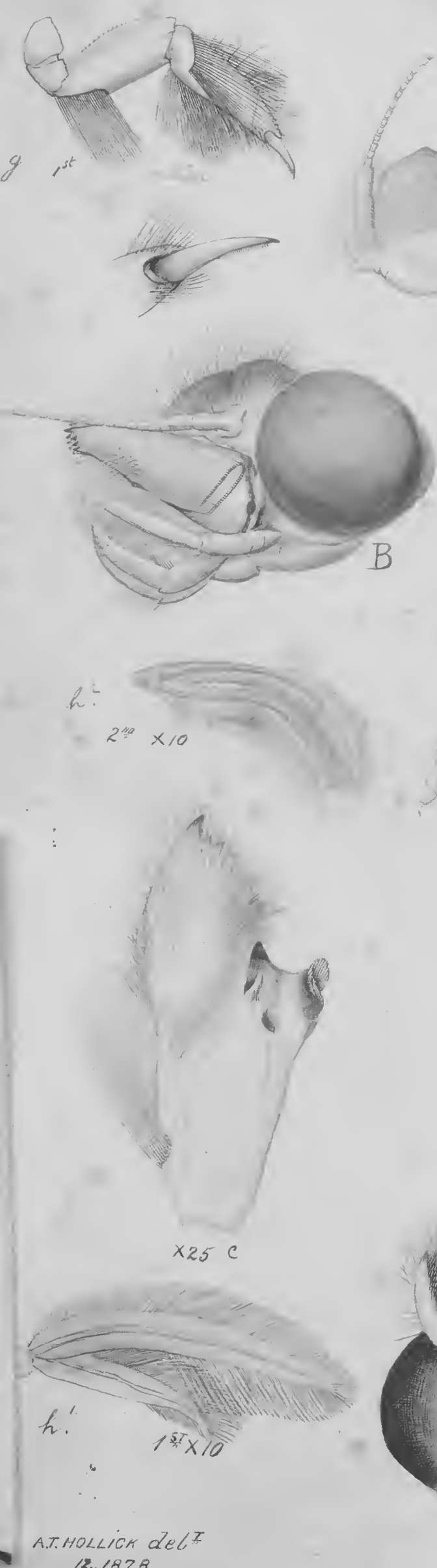

A.T.HOLLICA dELT 12.1878
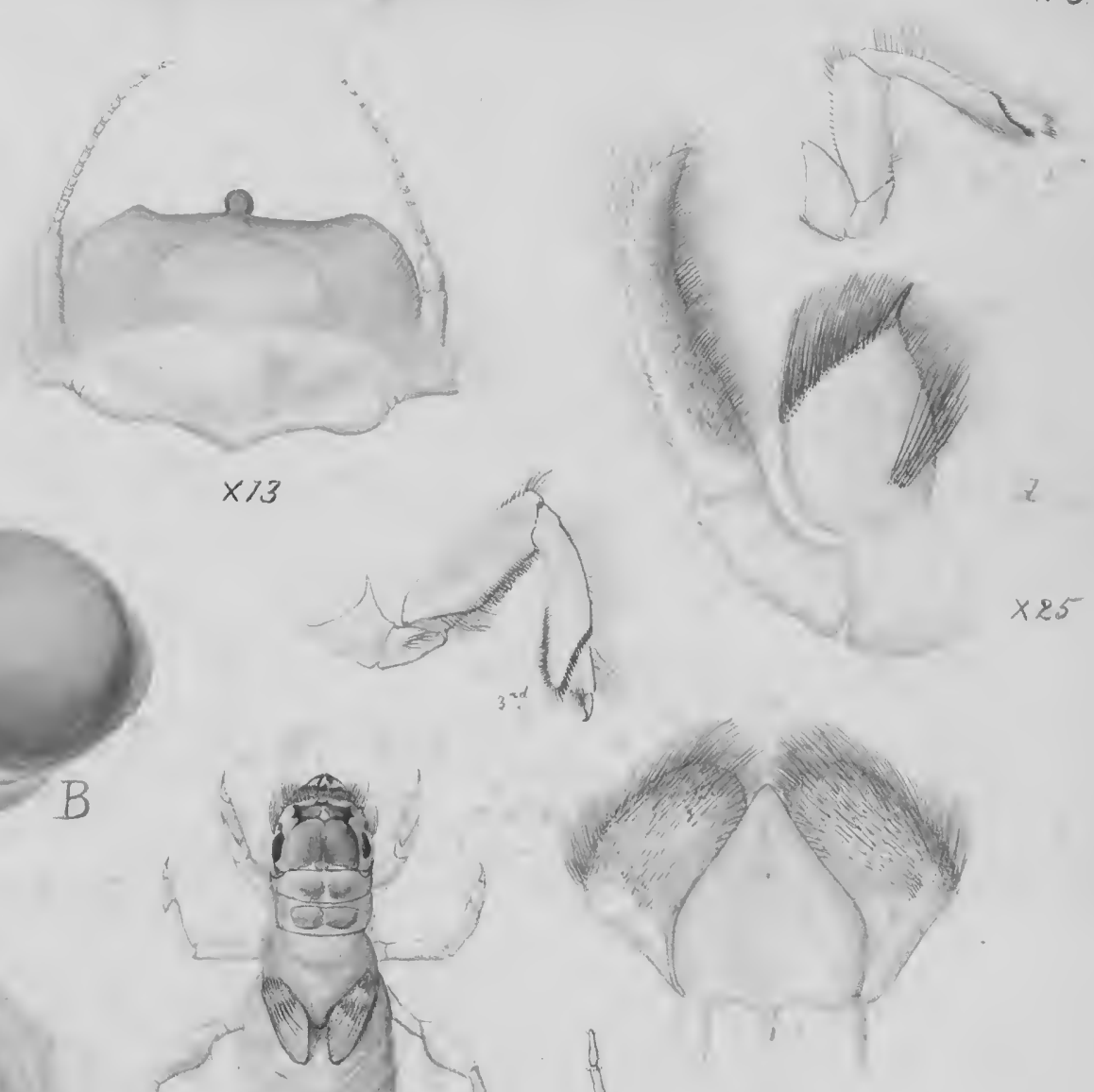

$\times 25 f$
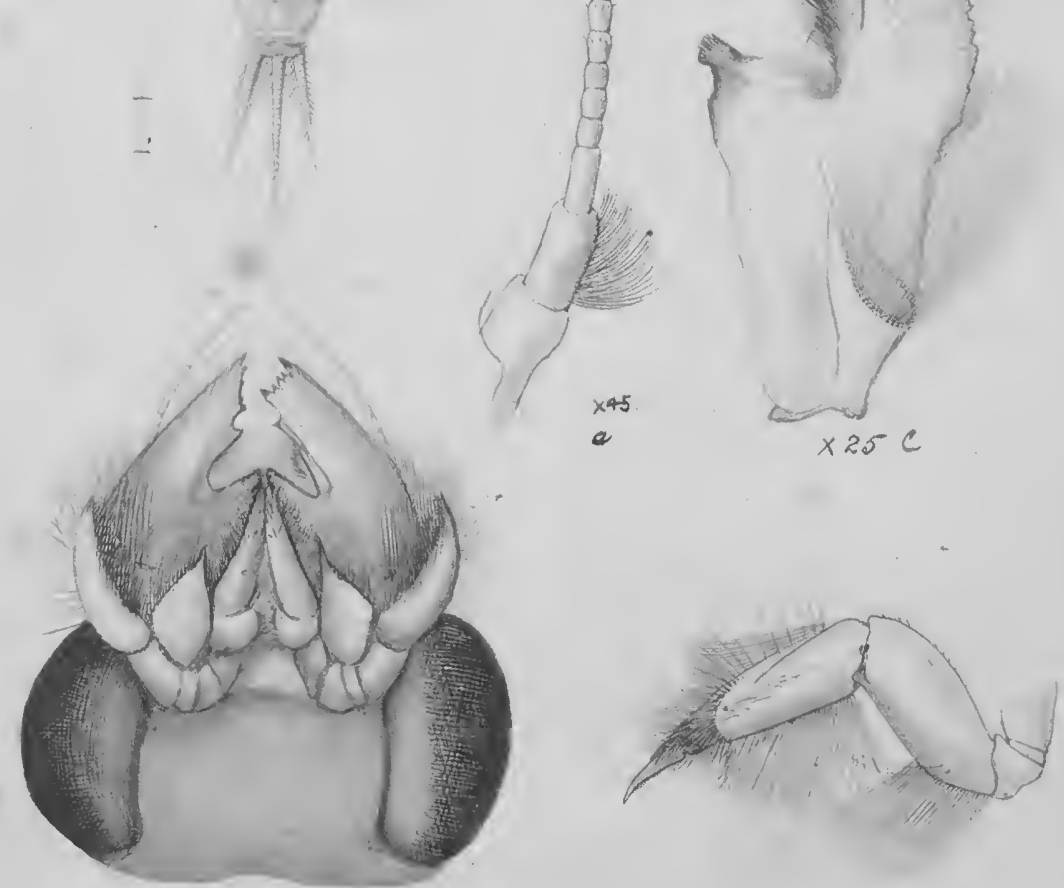

C 


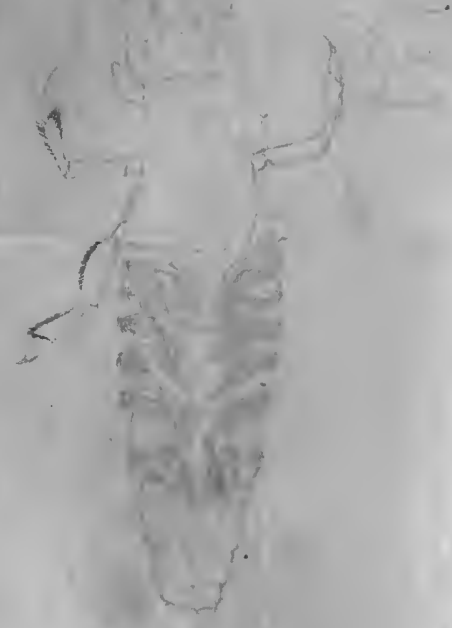


Palingenia allieá to Iata
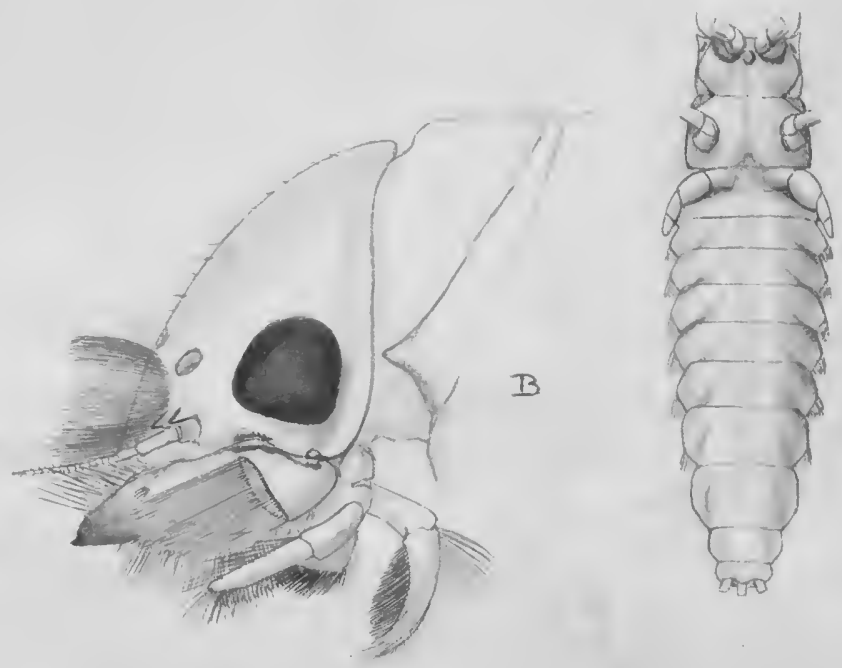

$\times 11$ 


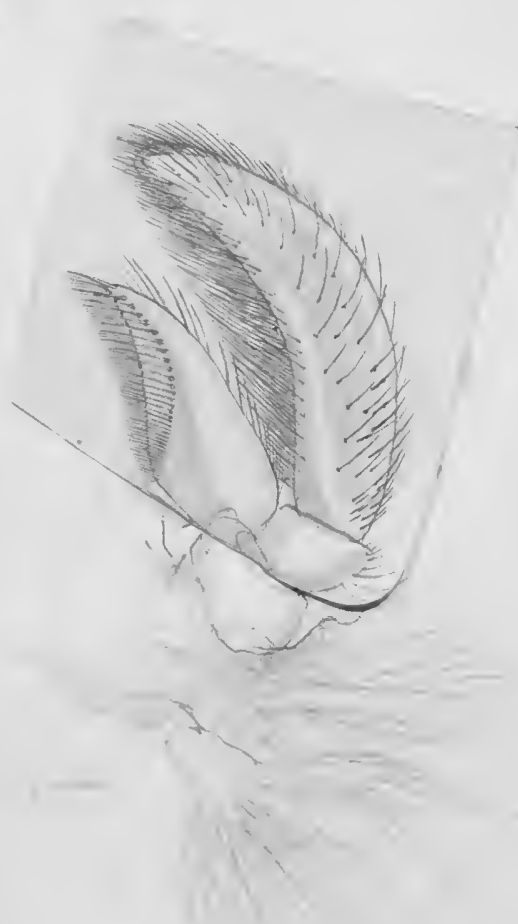


Oligoneuria.

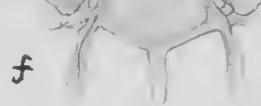

$\times 30$
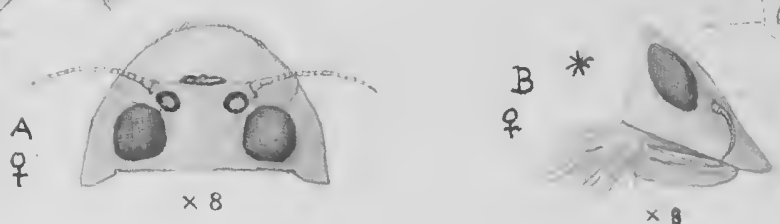

q
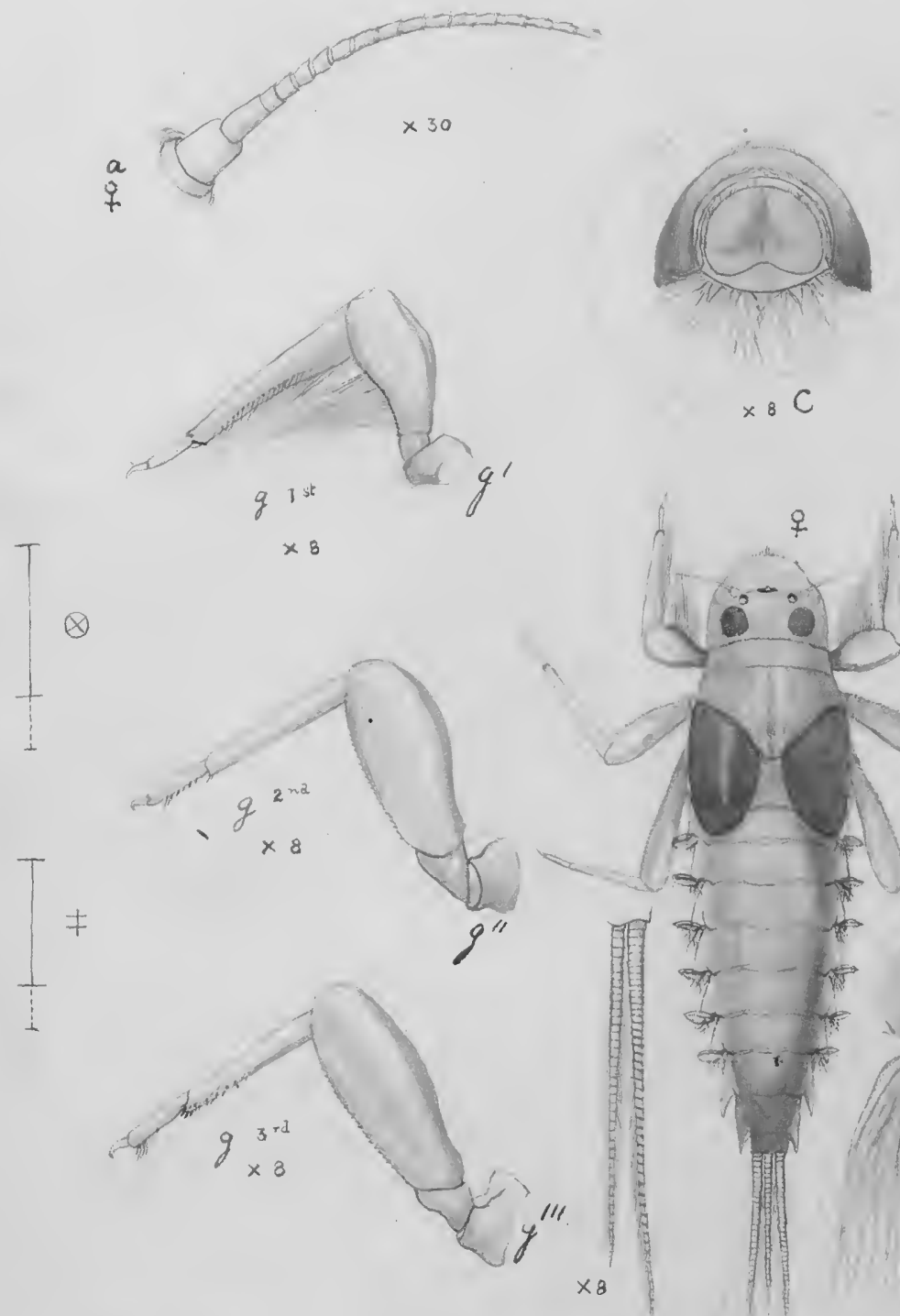

$\times 8 \mathrm{C}$

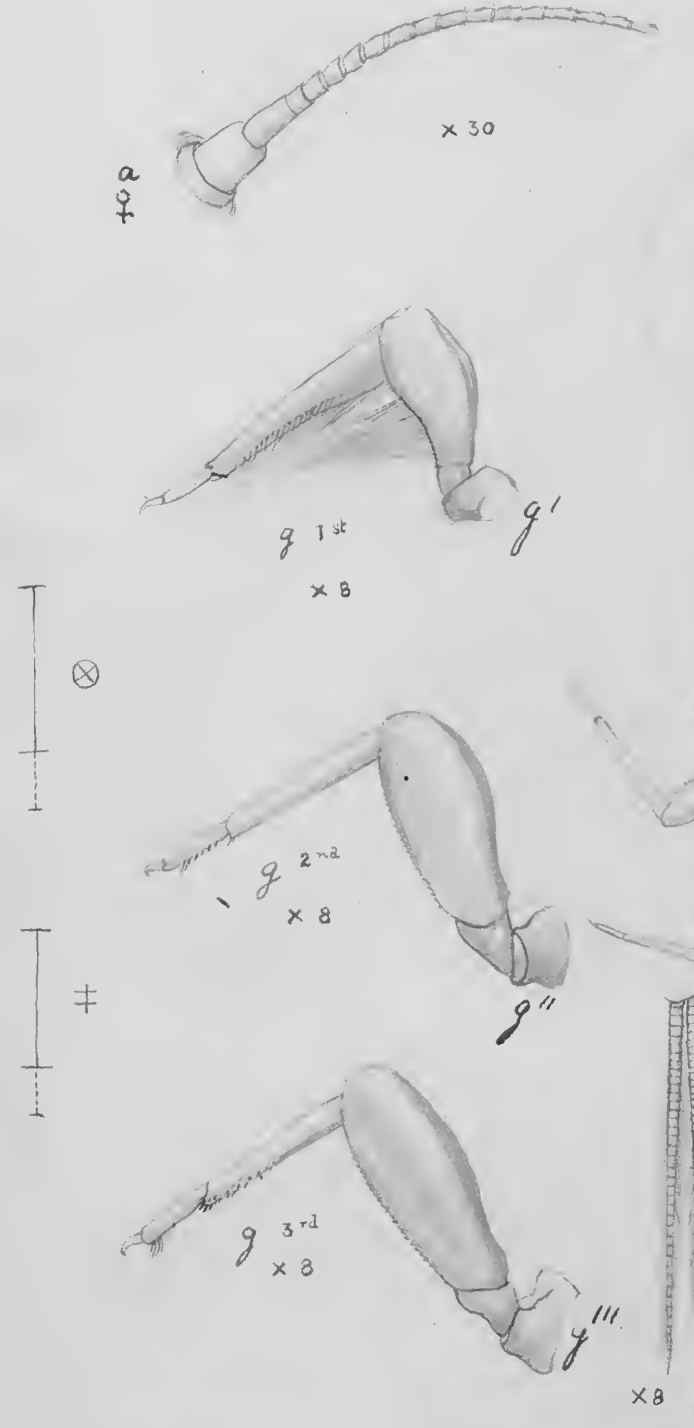

$\otimes$
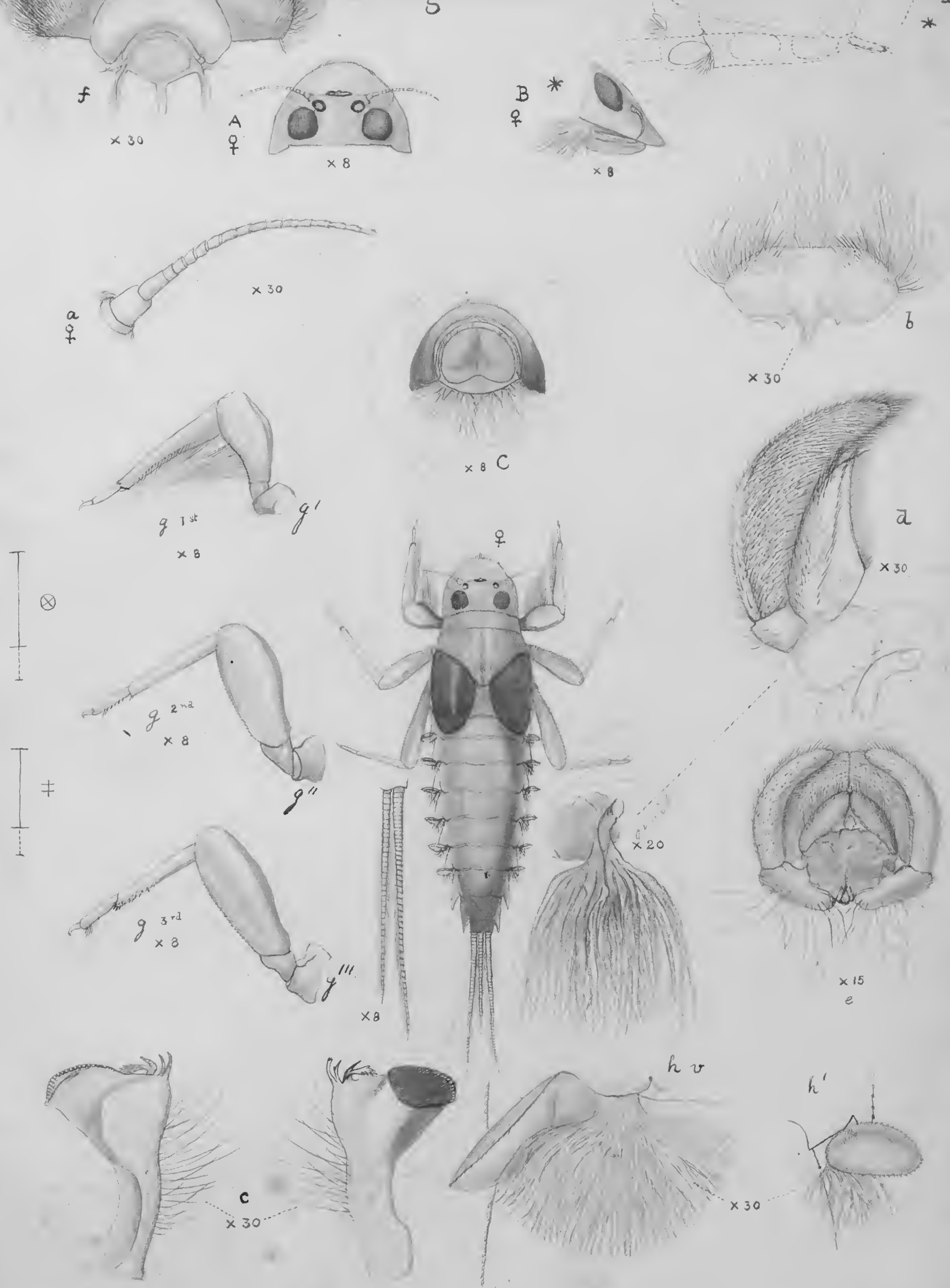


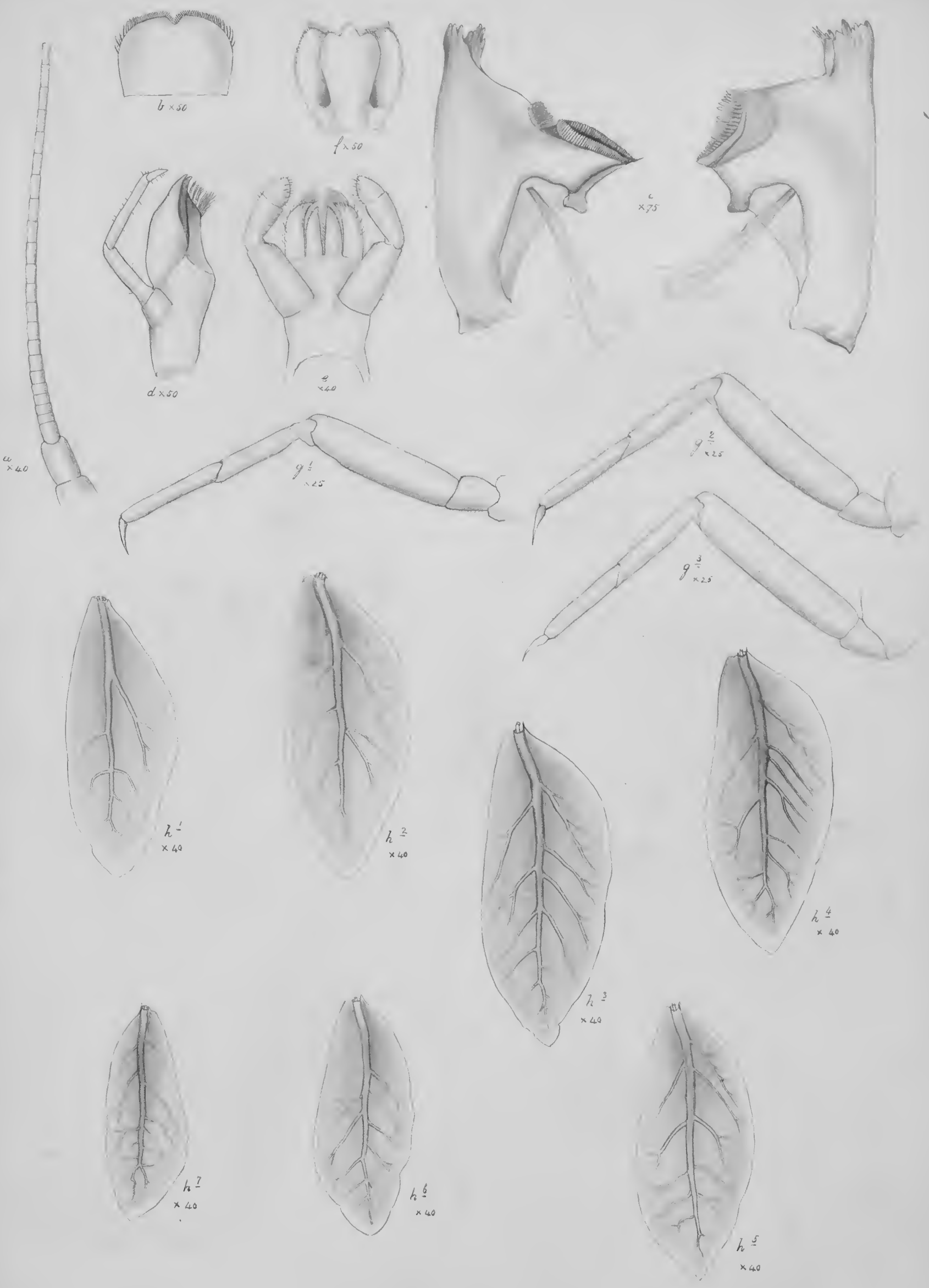



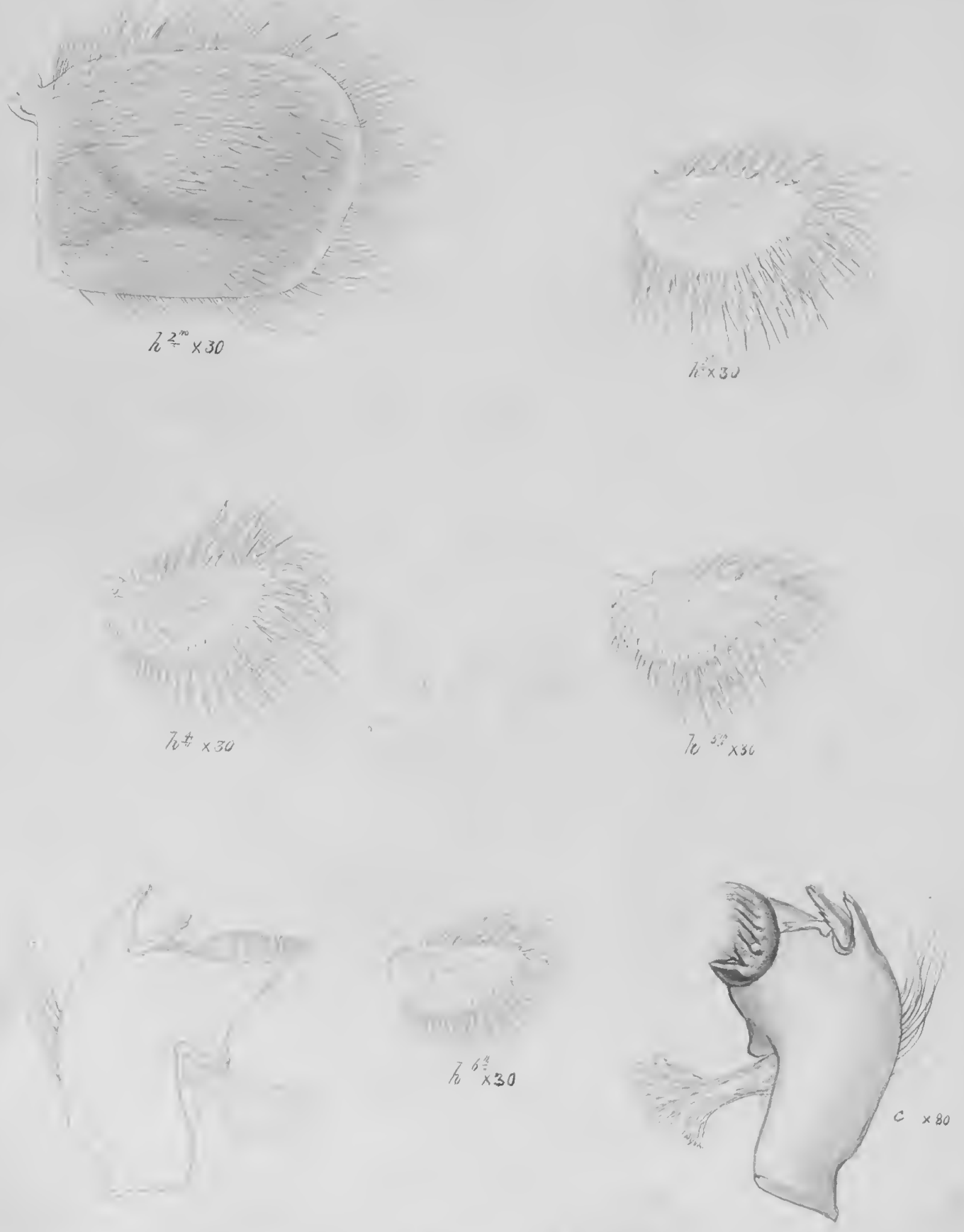

Eecruis 

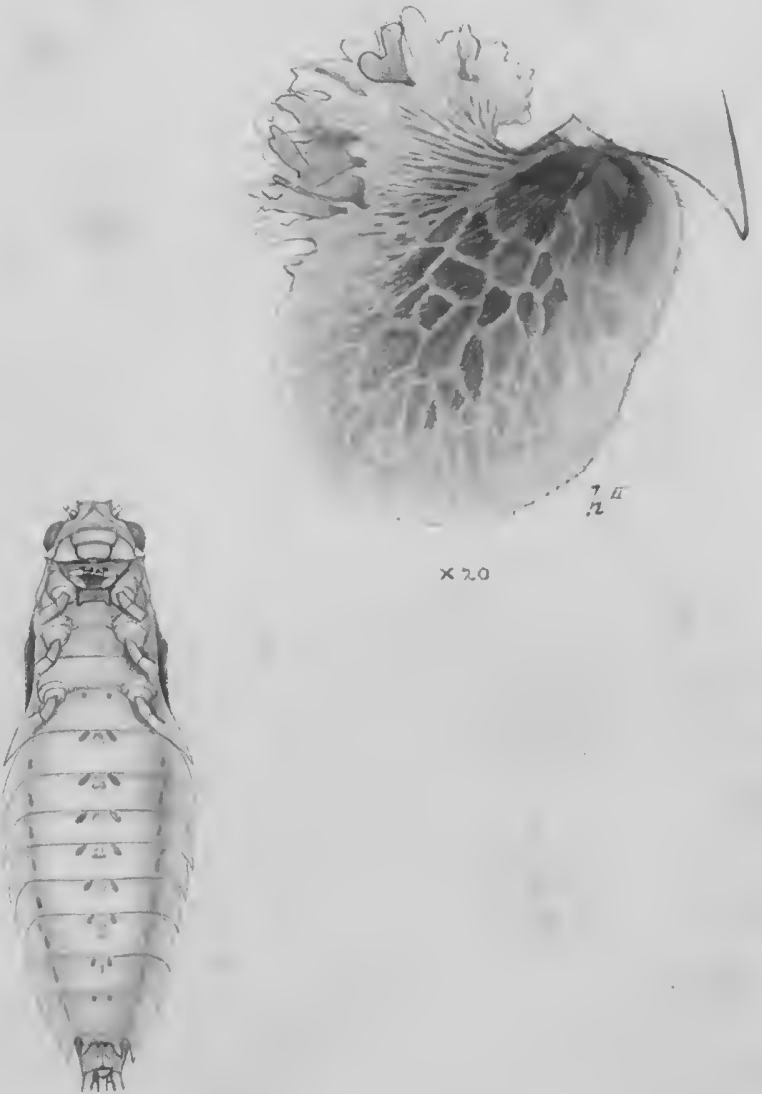

Oniscigaster Wakefieldi 

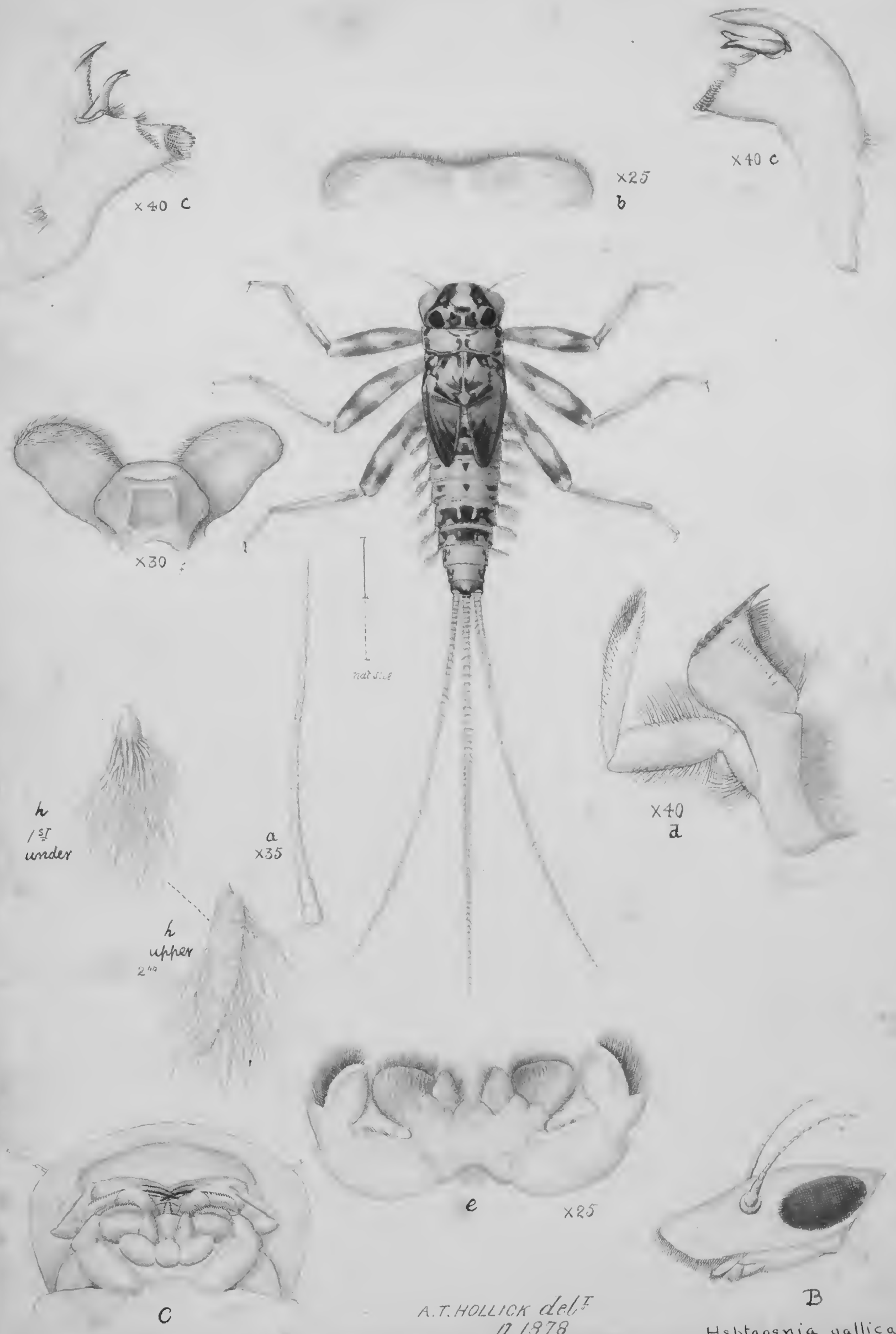


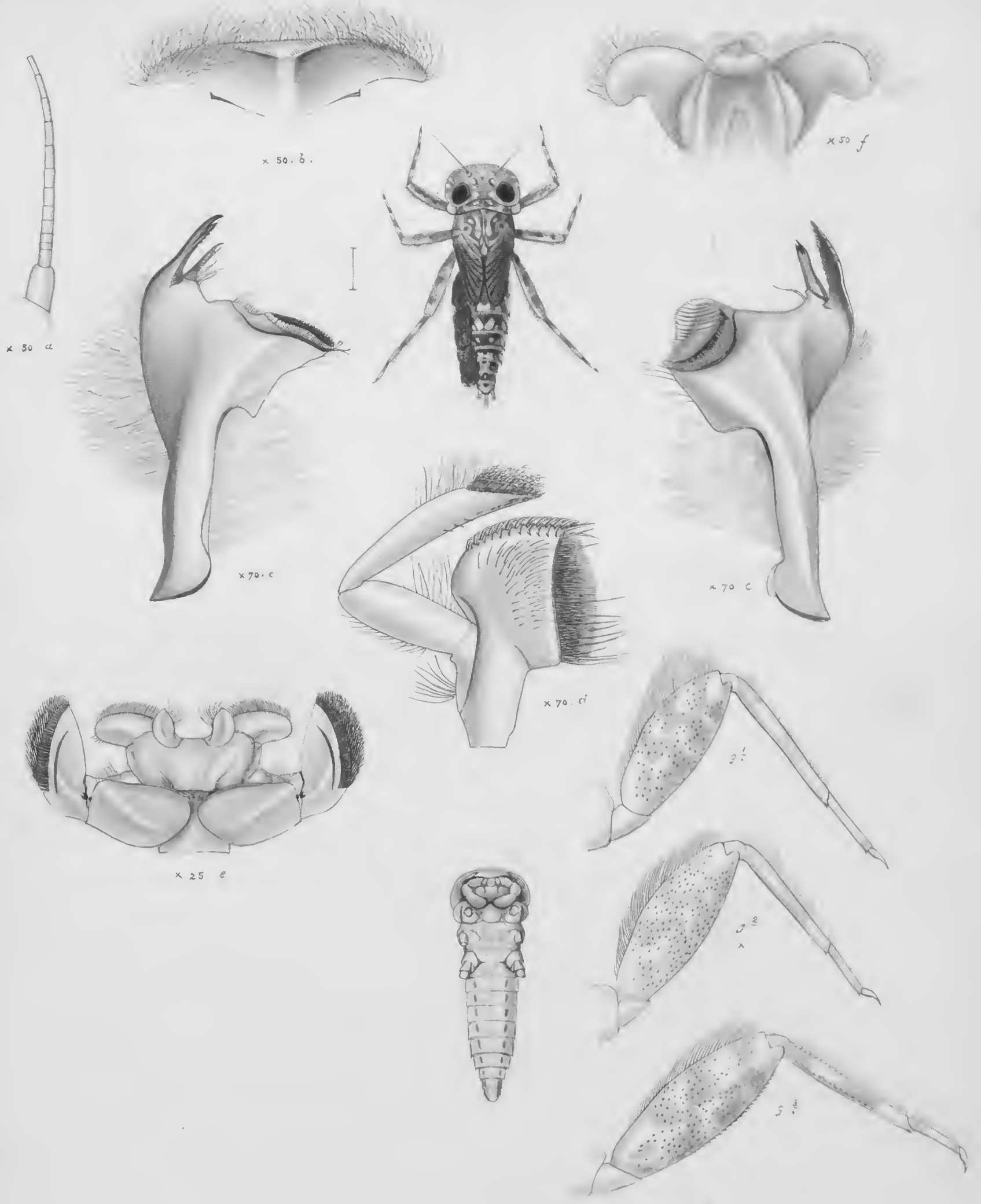




$$
M_{n}
$$




$$
11
$$


I
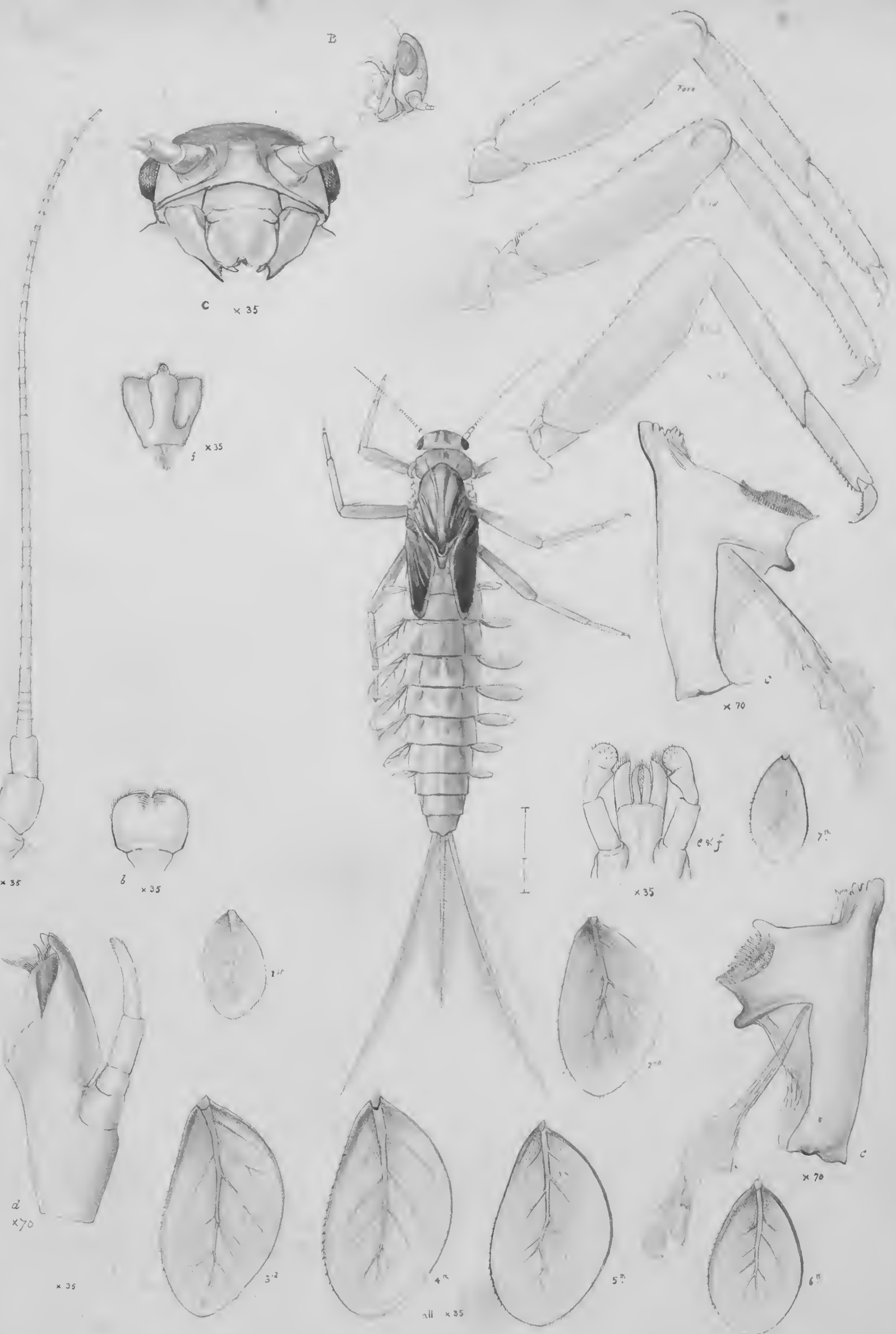


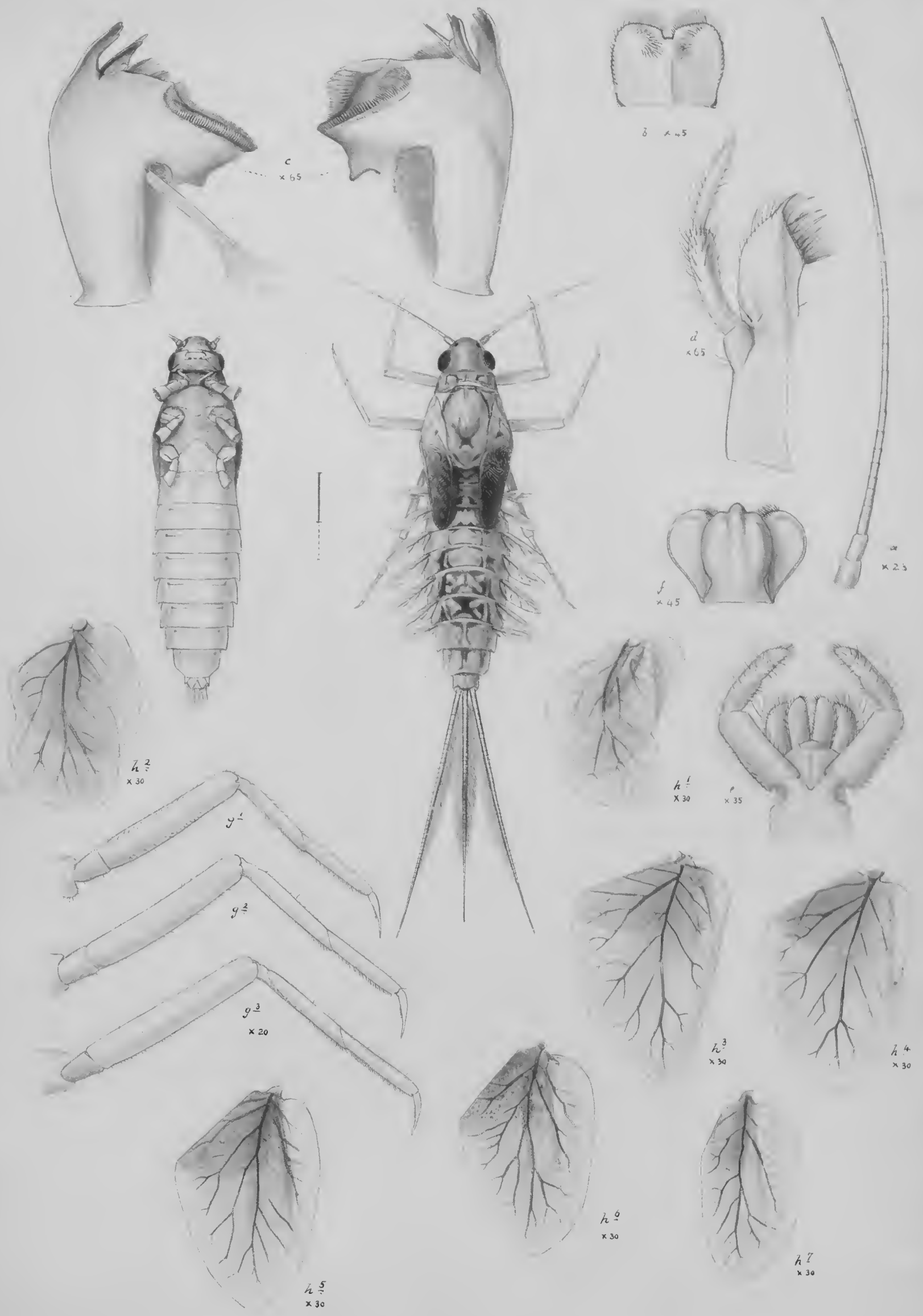




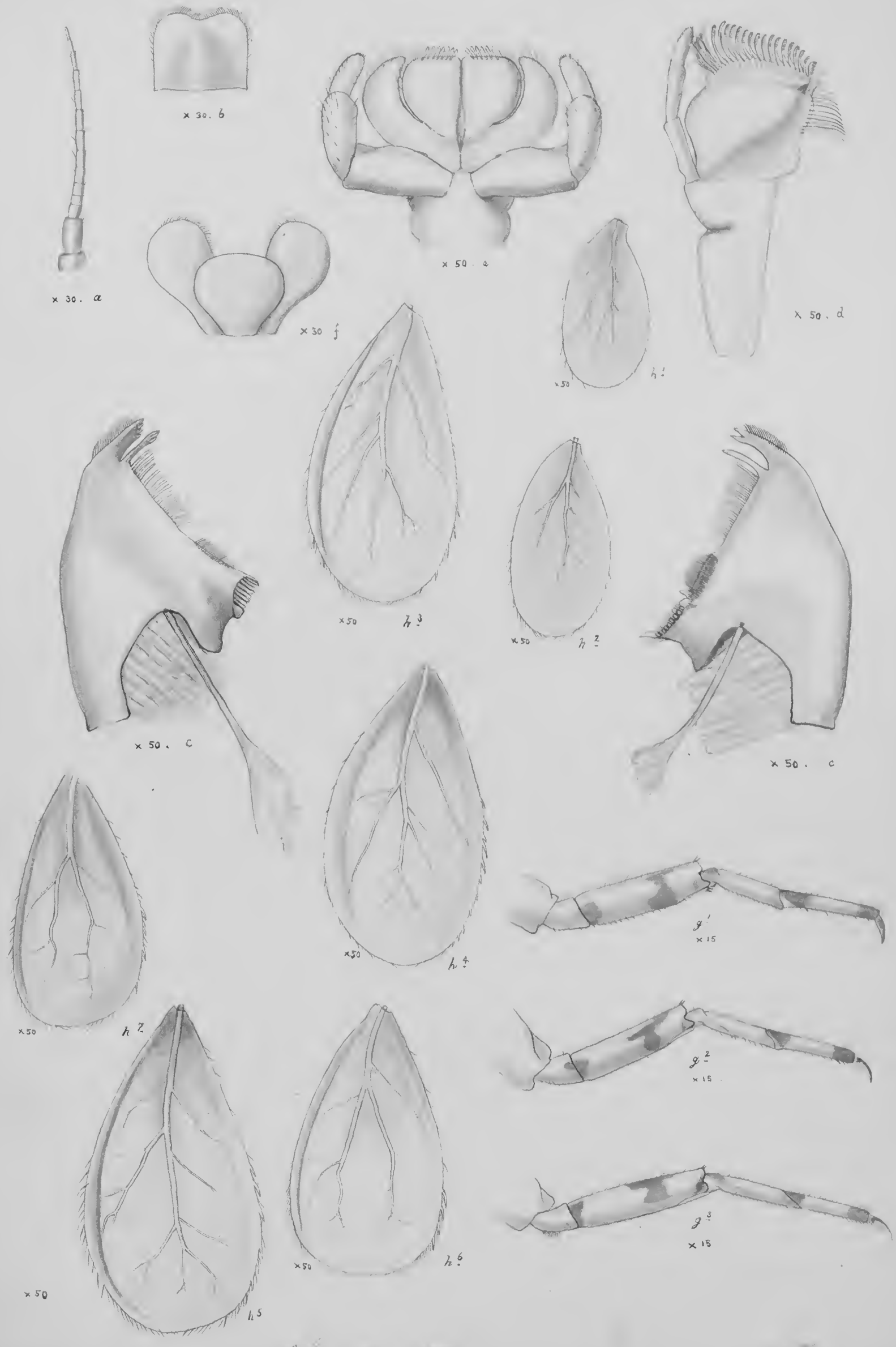


11 

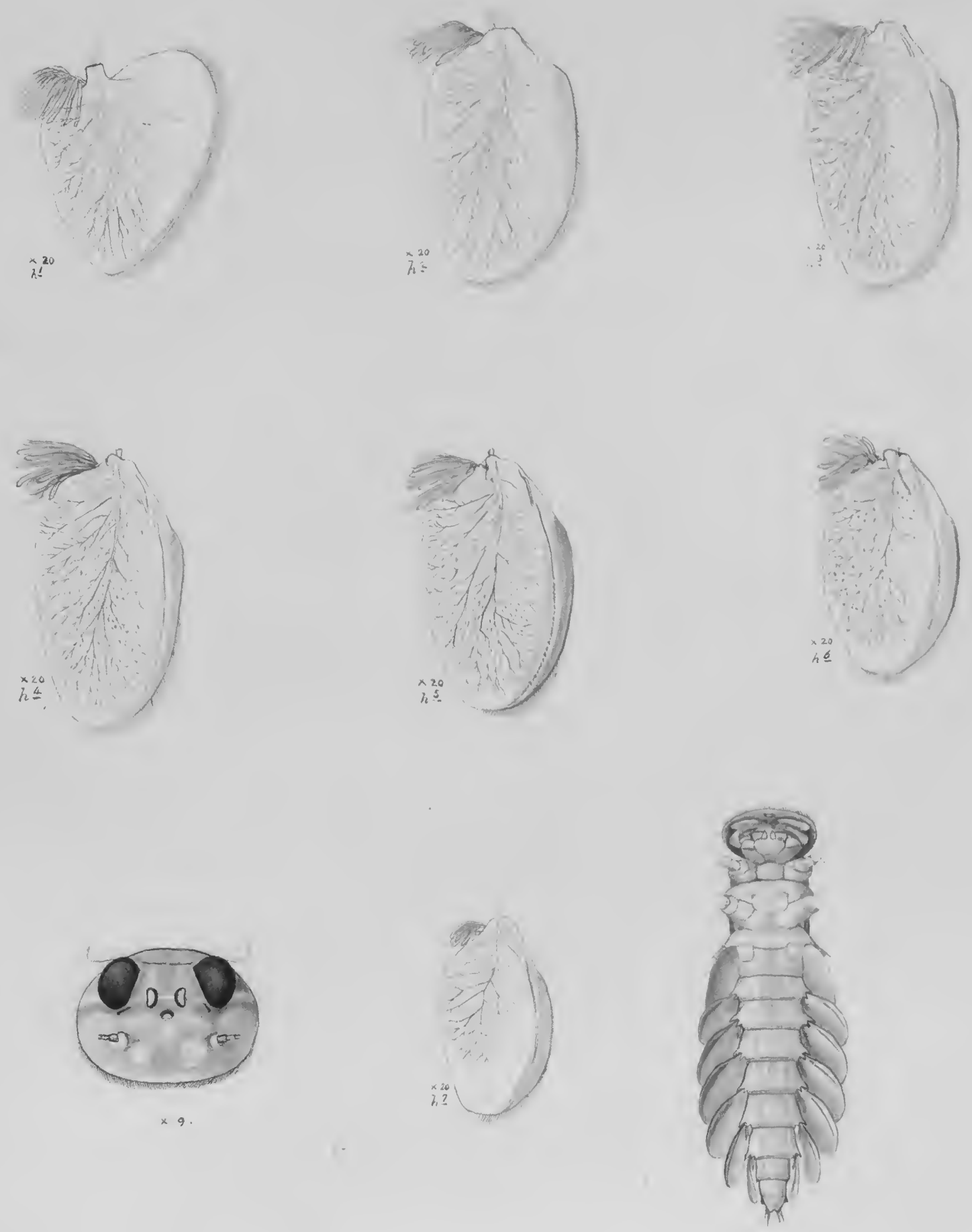


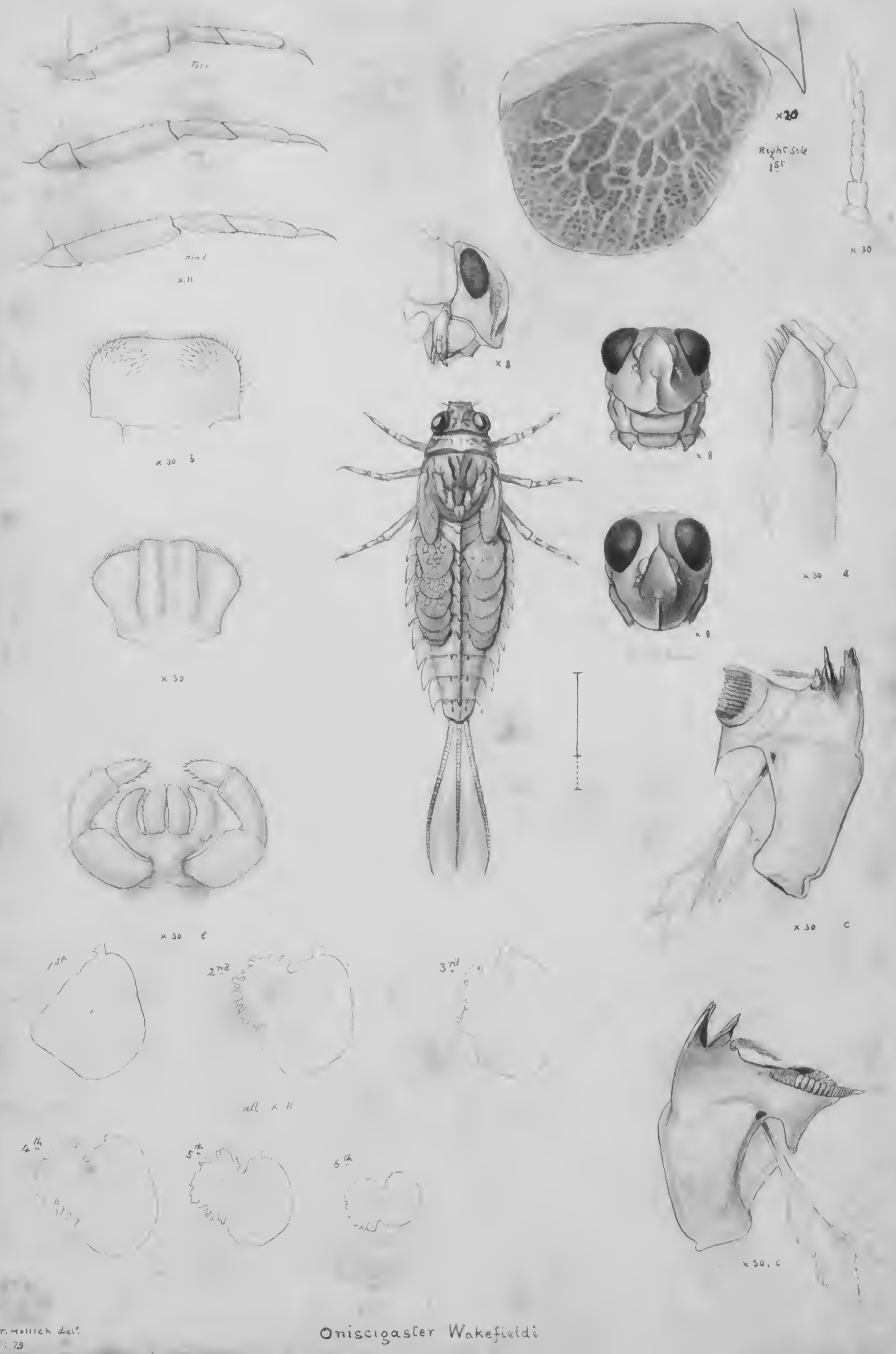




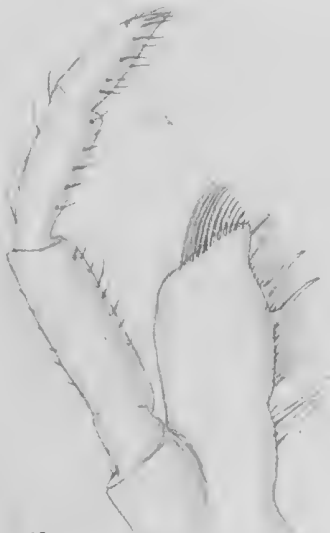




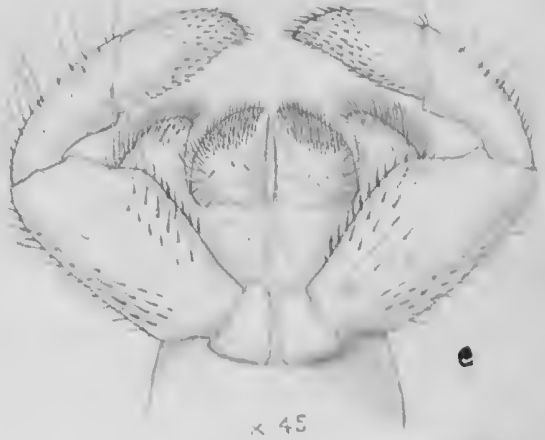


Siphlurus lacustris
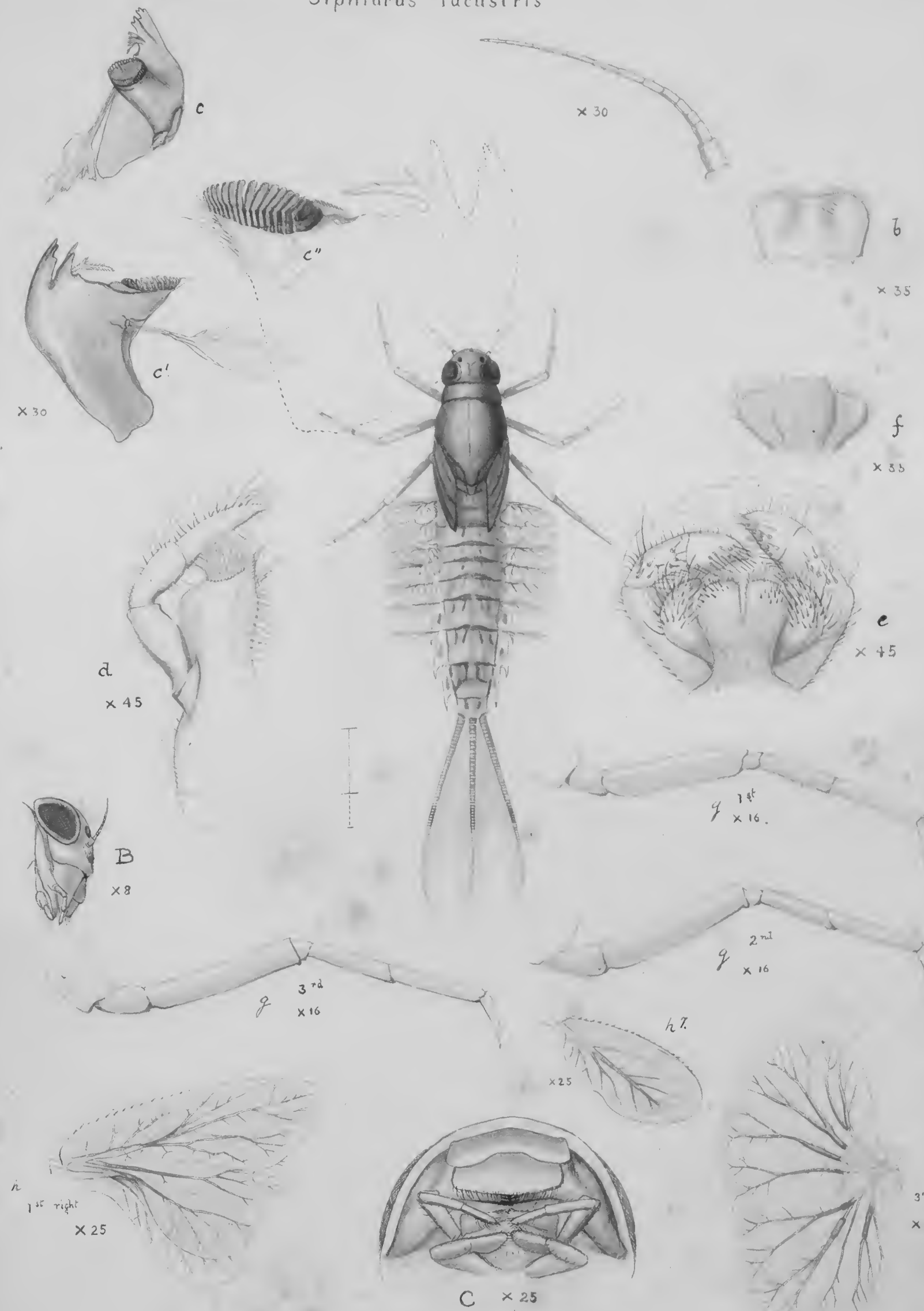


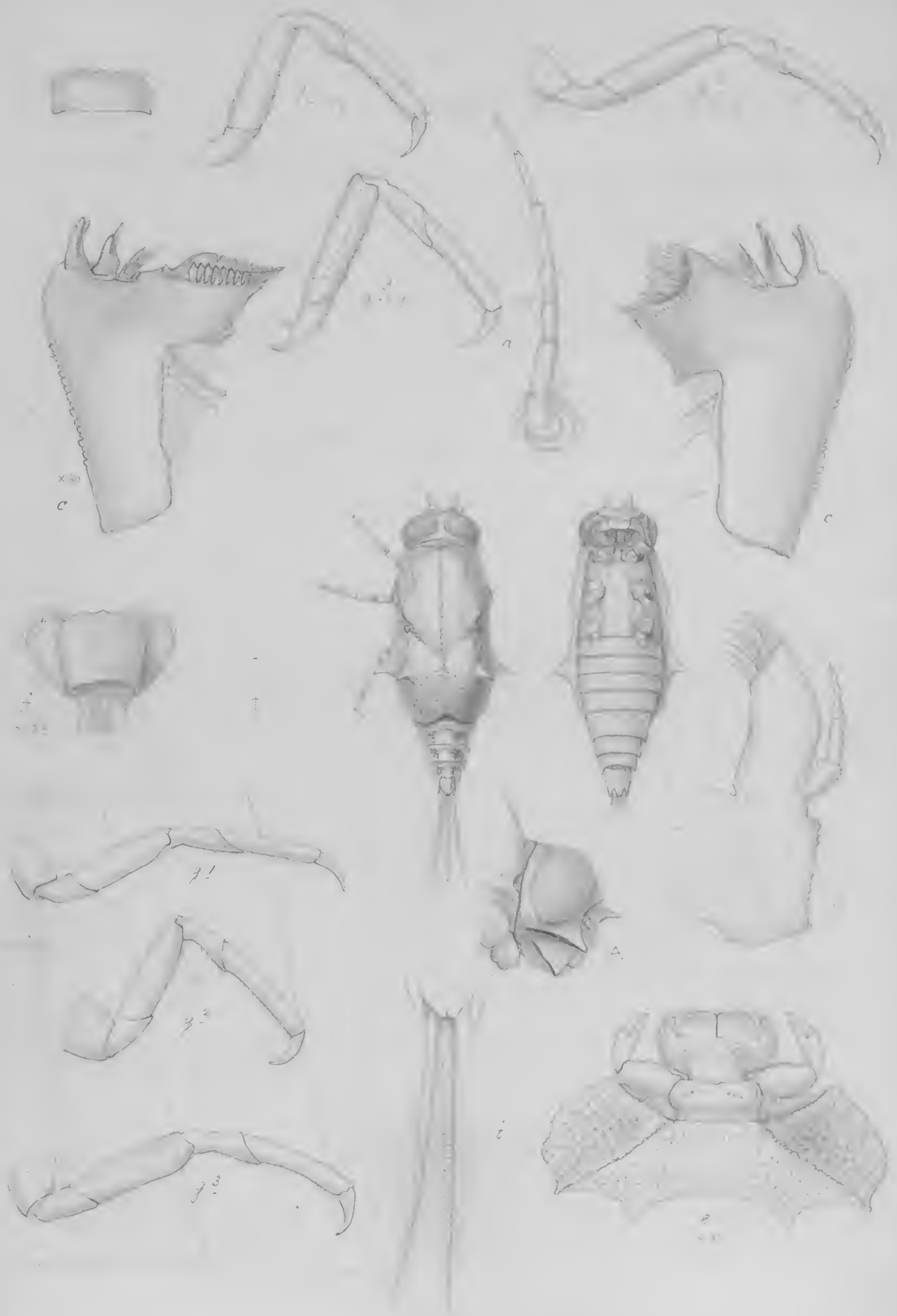



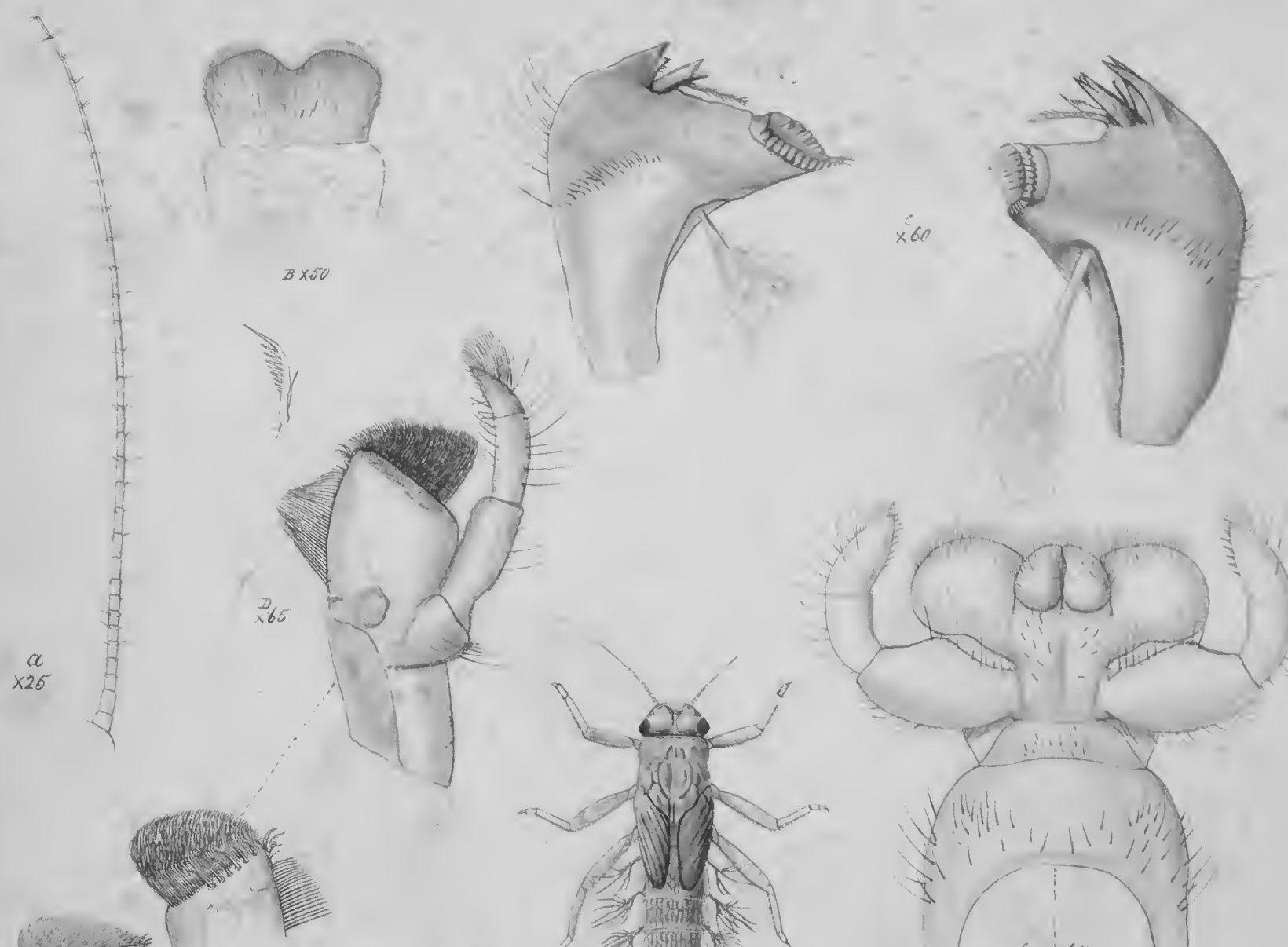

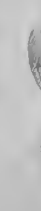
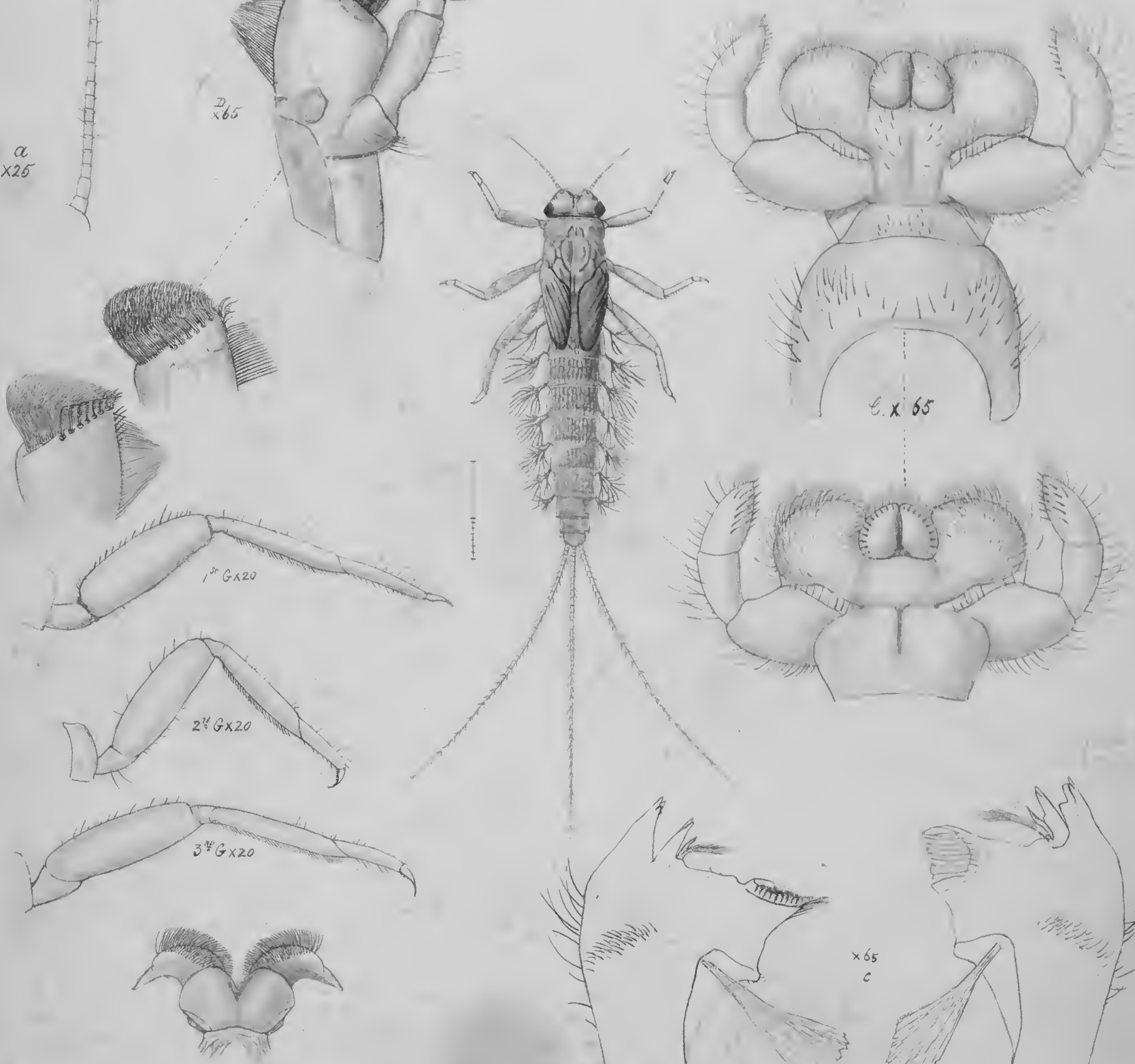

y待

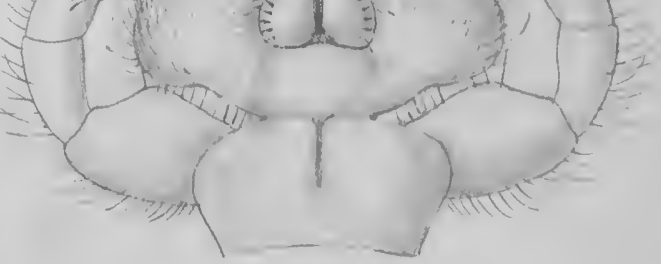



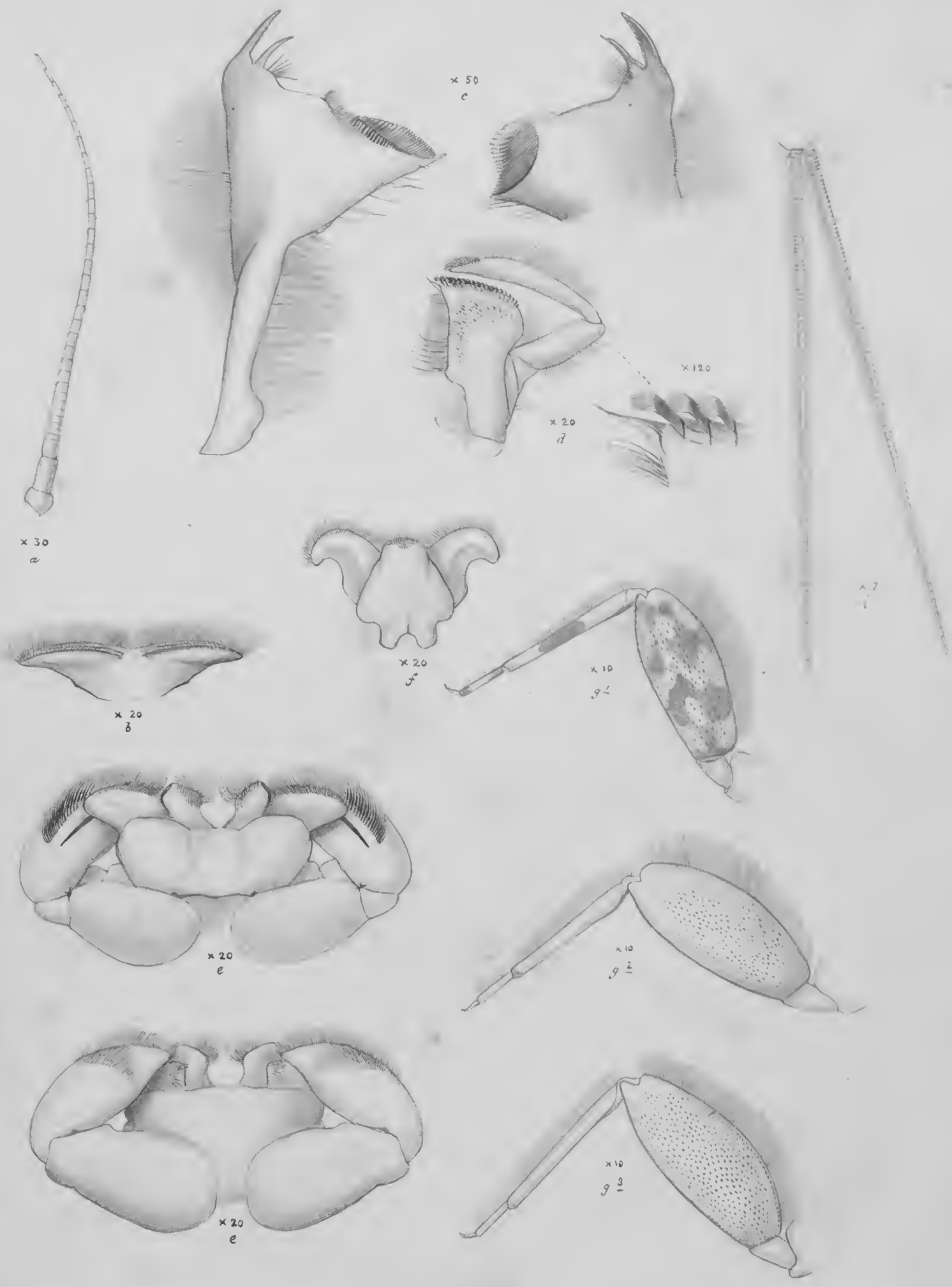


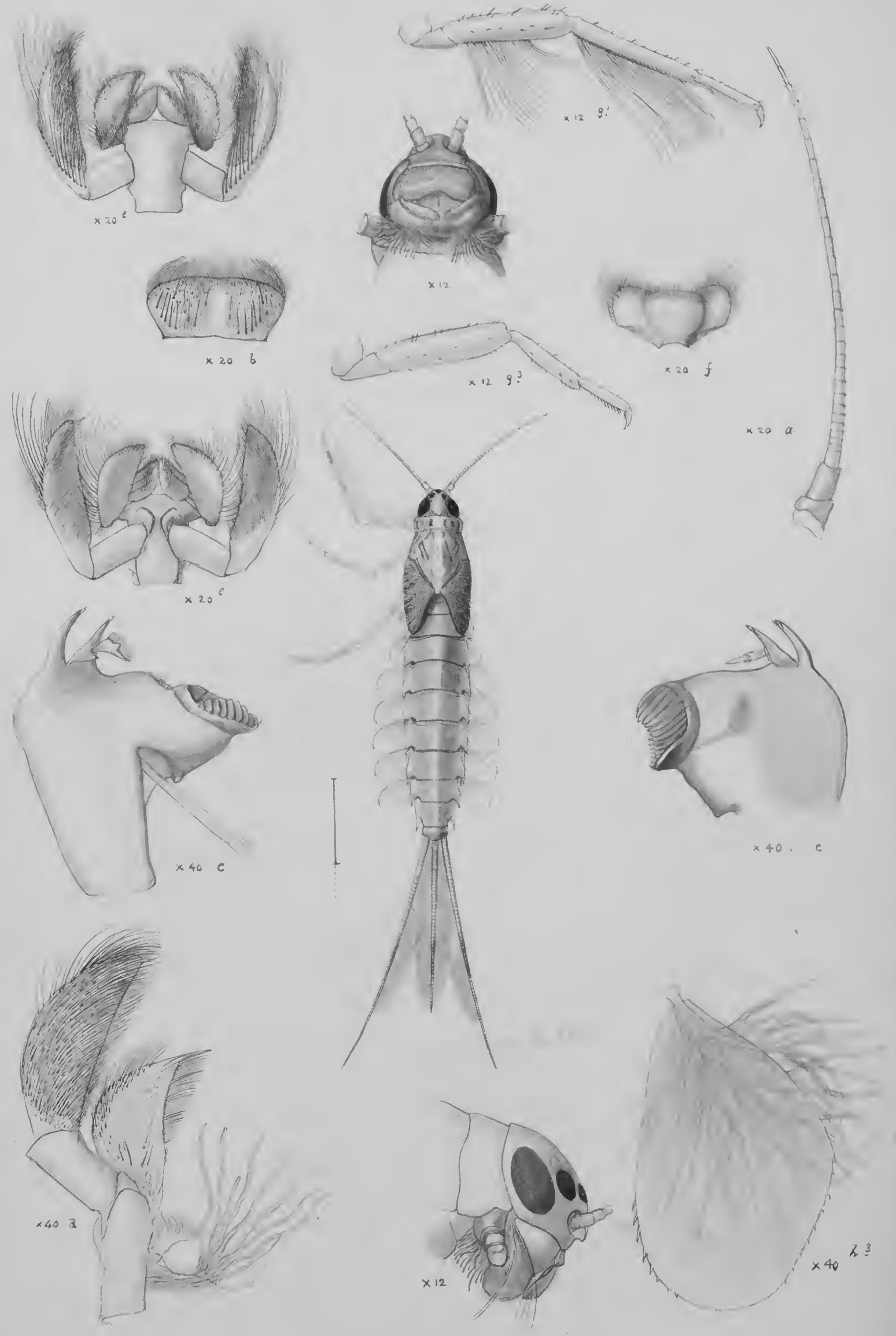

Jolia roselii 

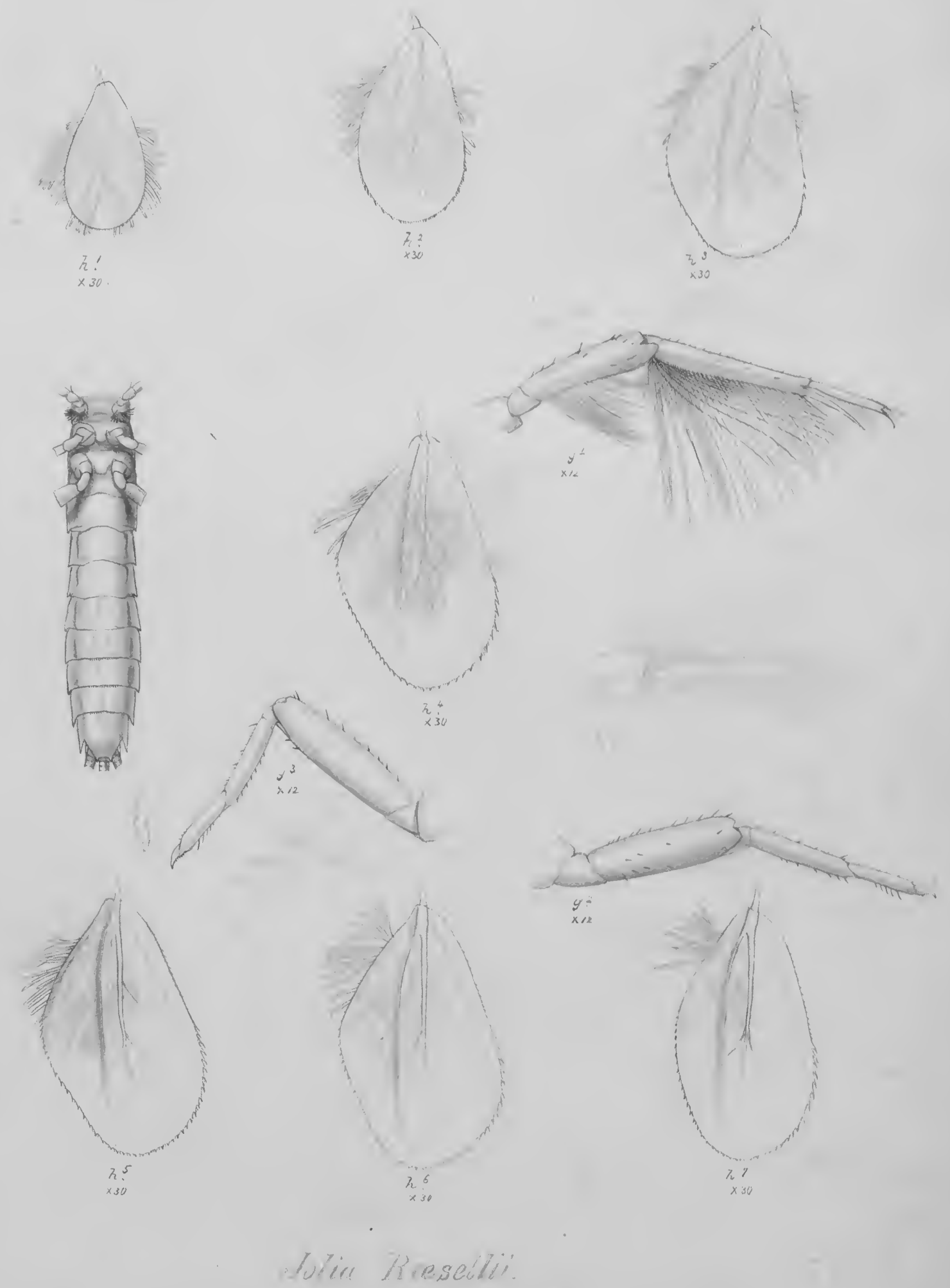

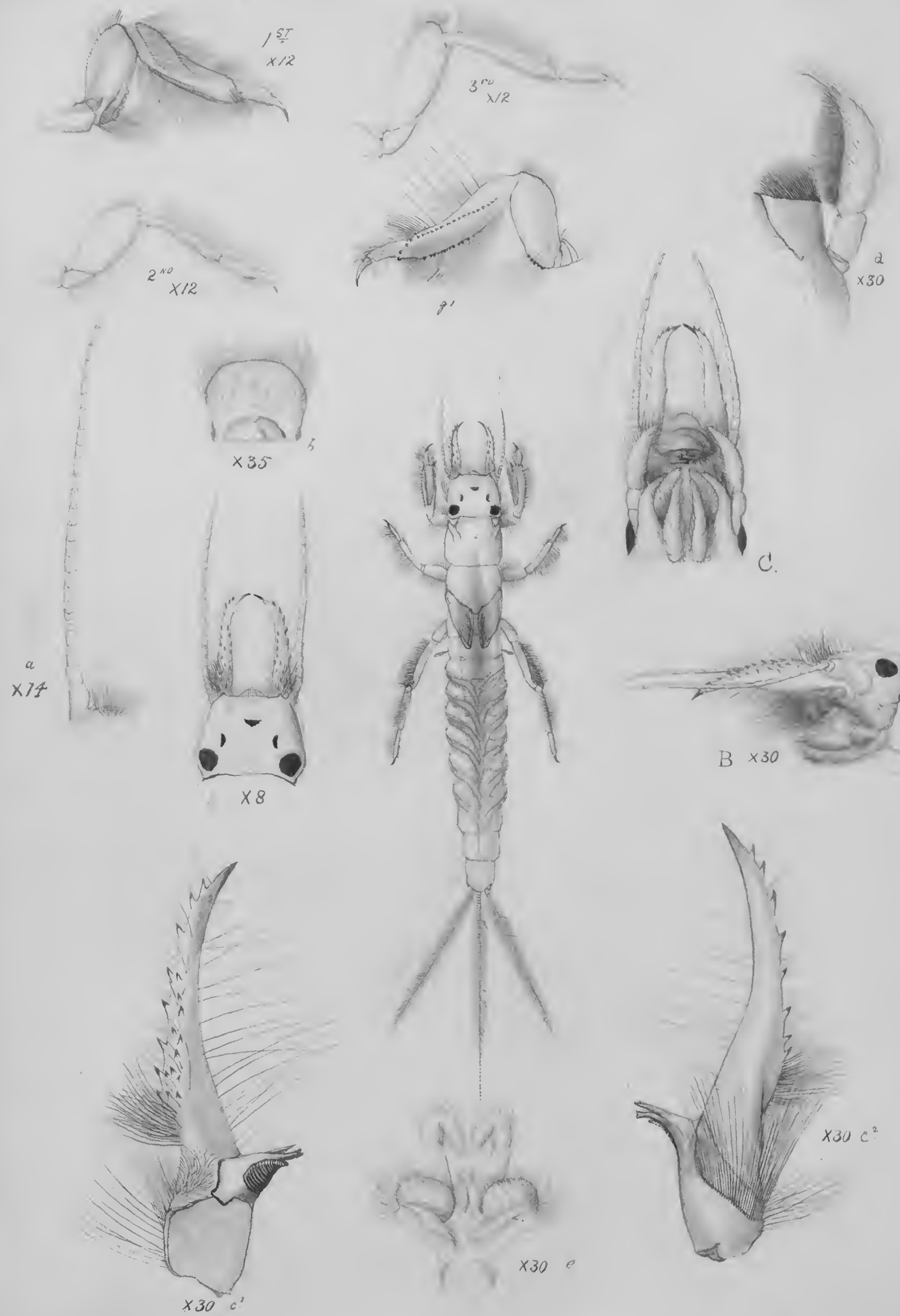

A.T.HOLLICK del?
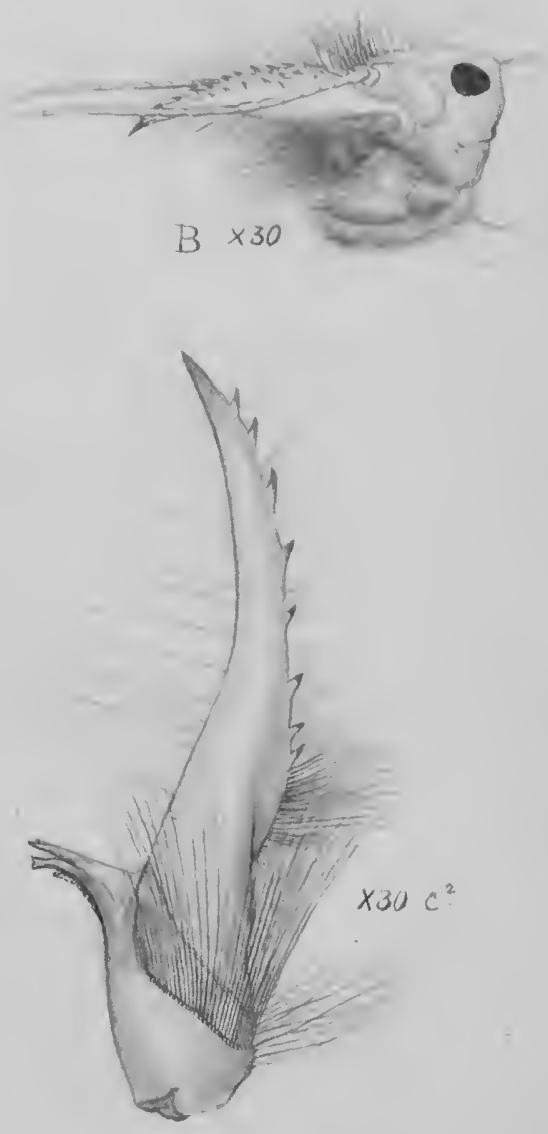

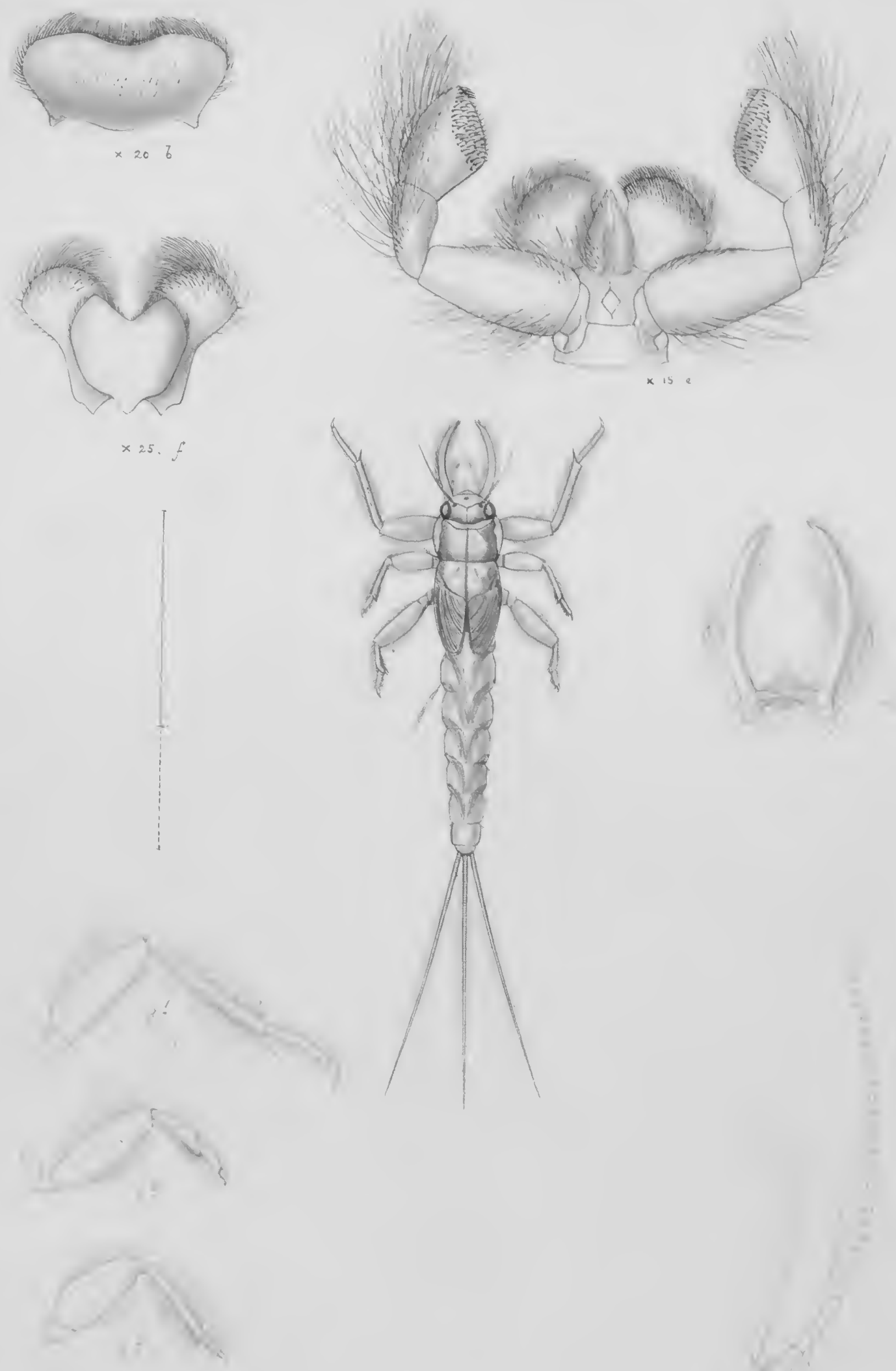
Polraitarcis Virgo

$V=5$
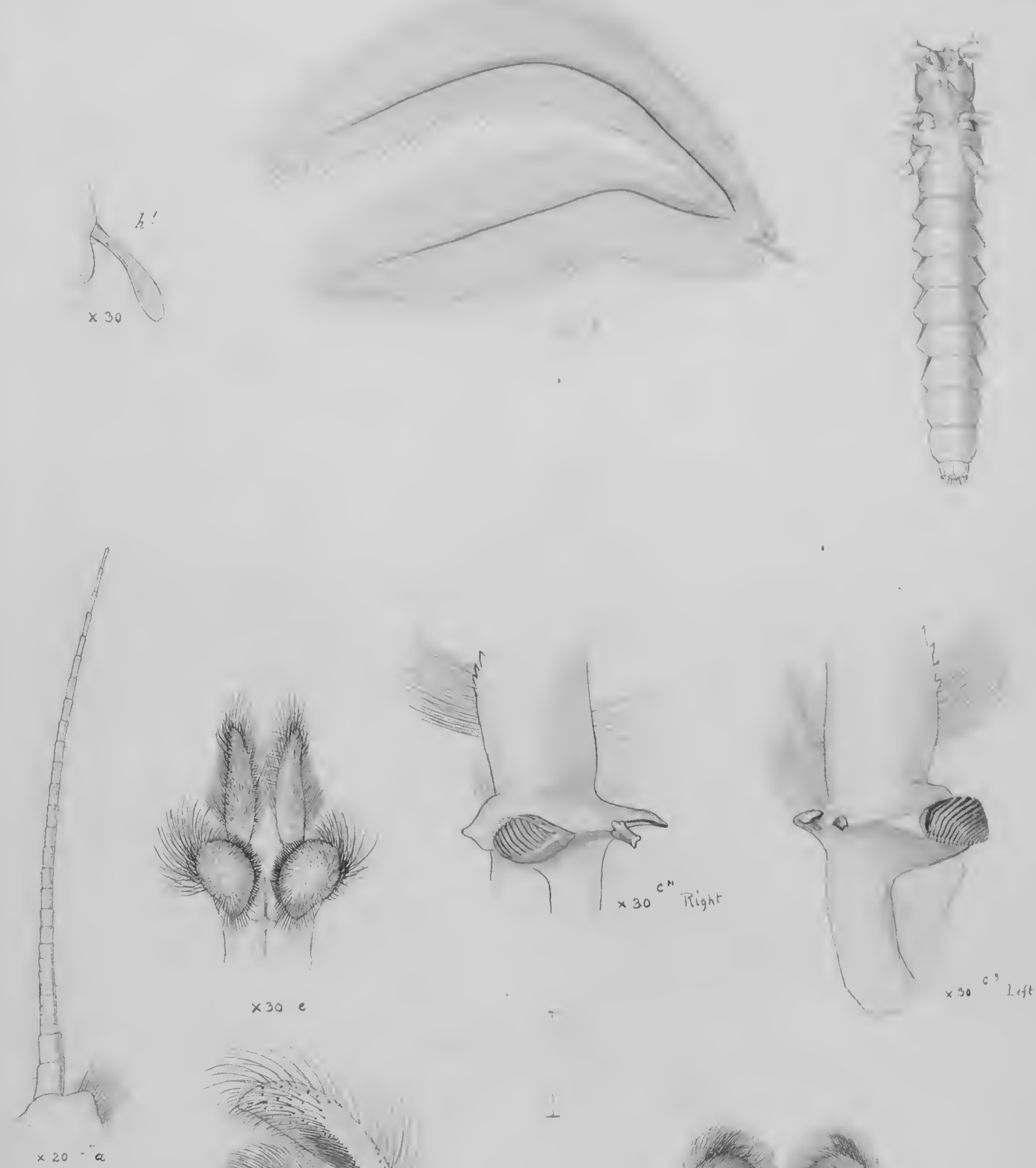

$\times 30 \mathrm{e}$
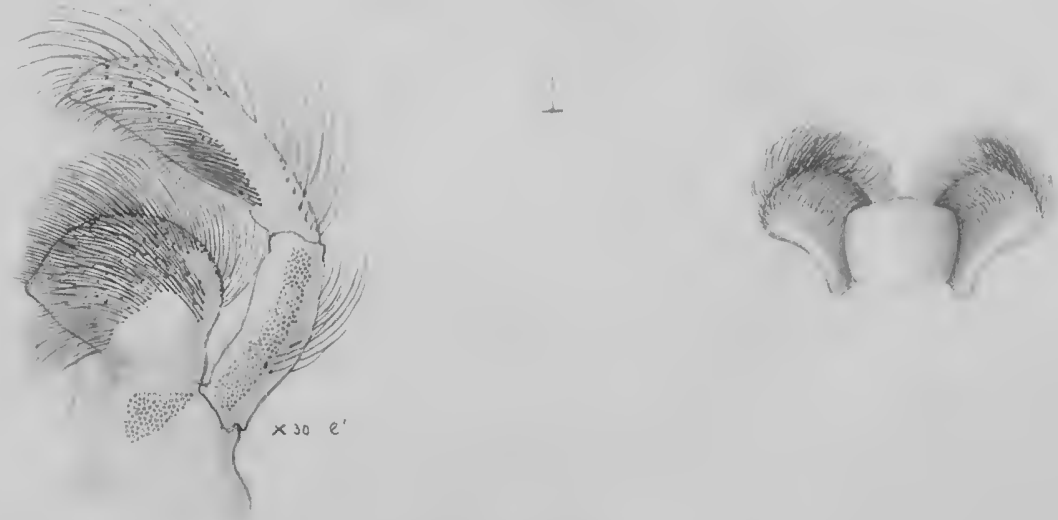

A.T. HOLLICK QELT 12. 1878 


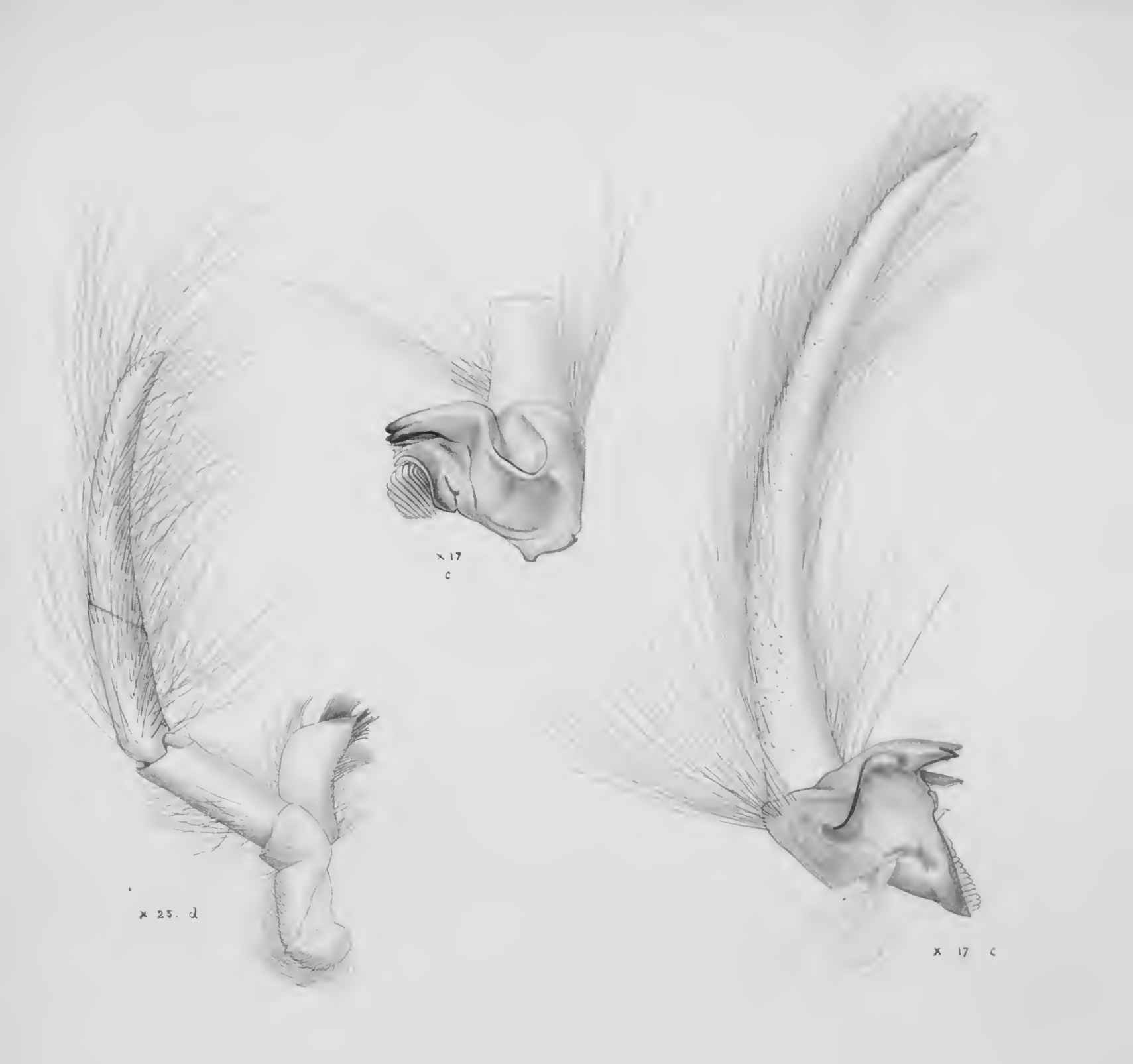




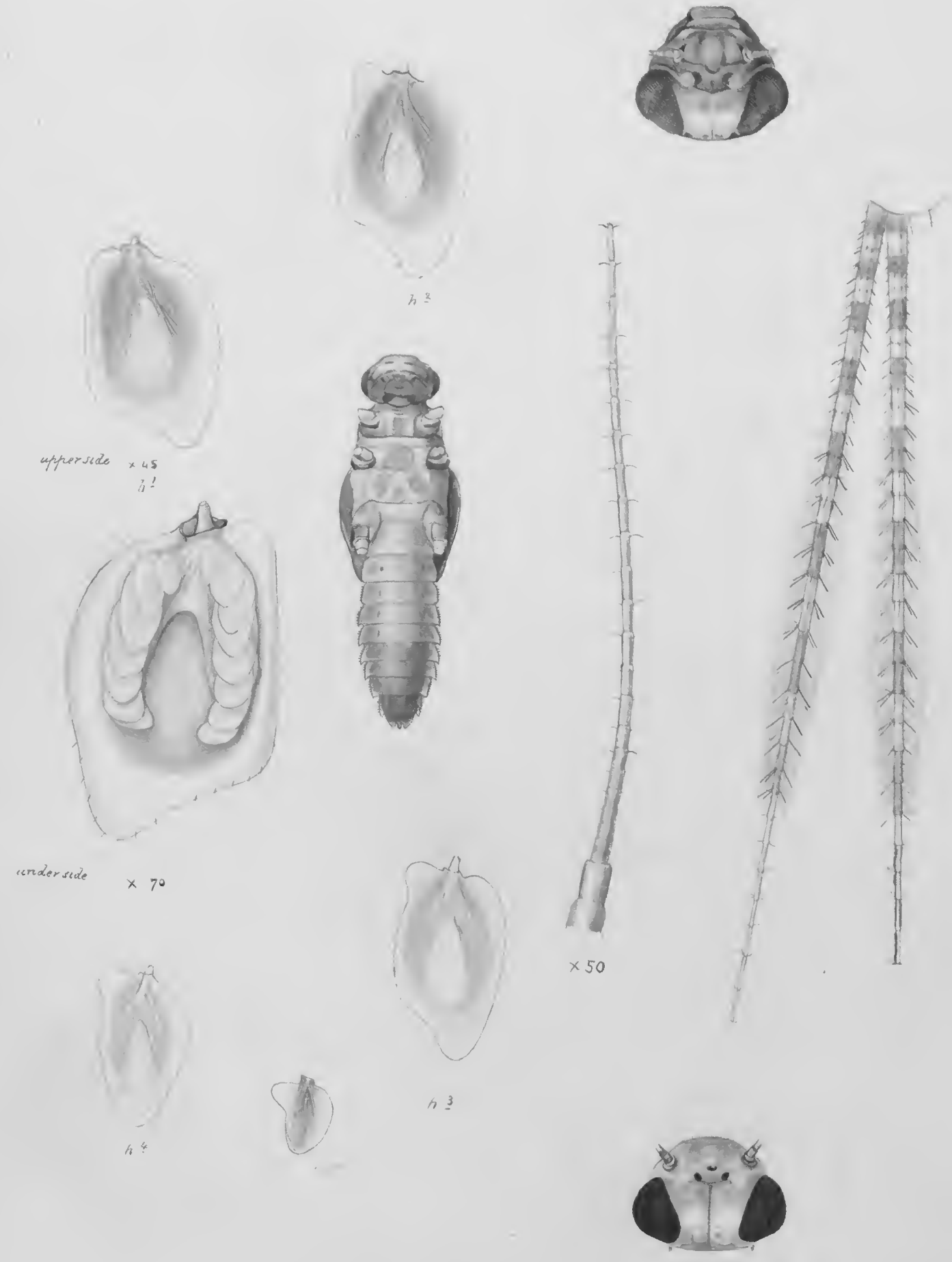




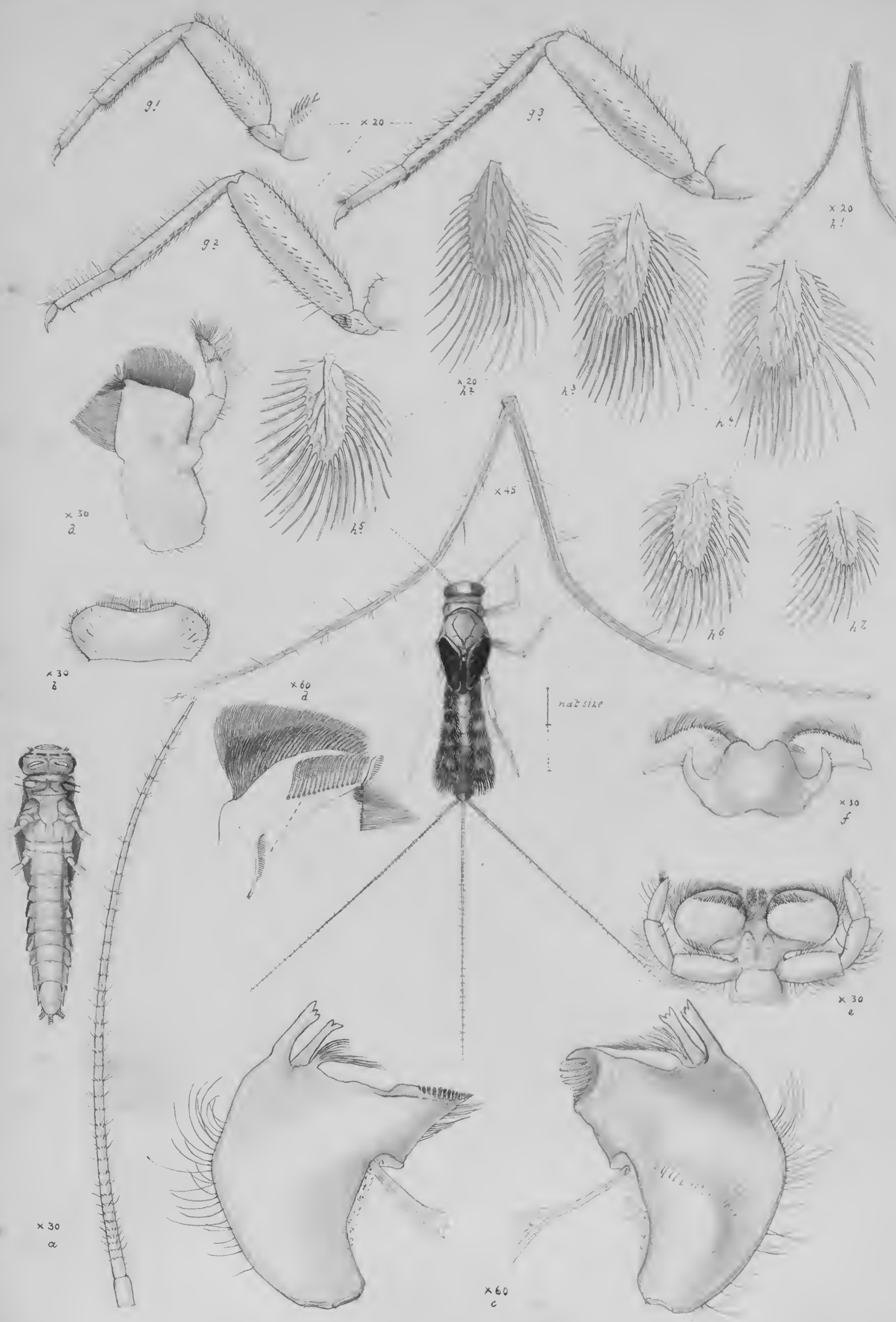




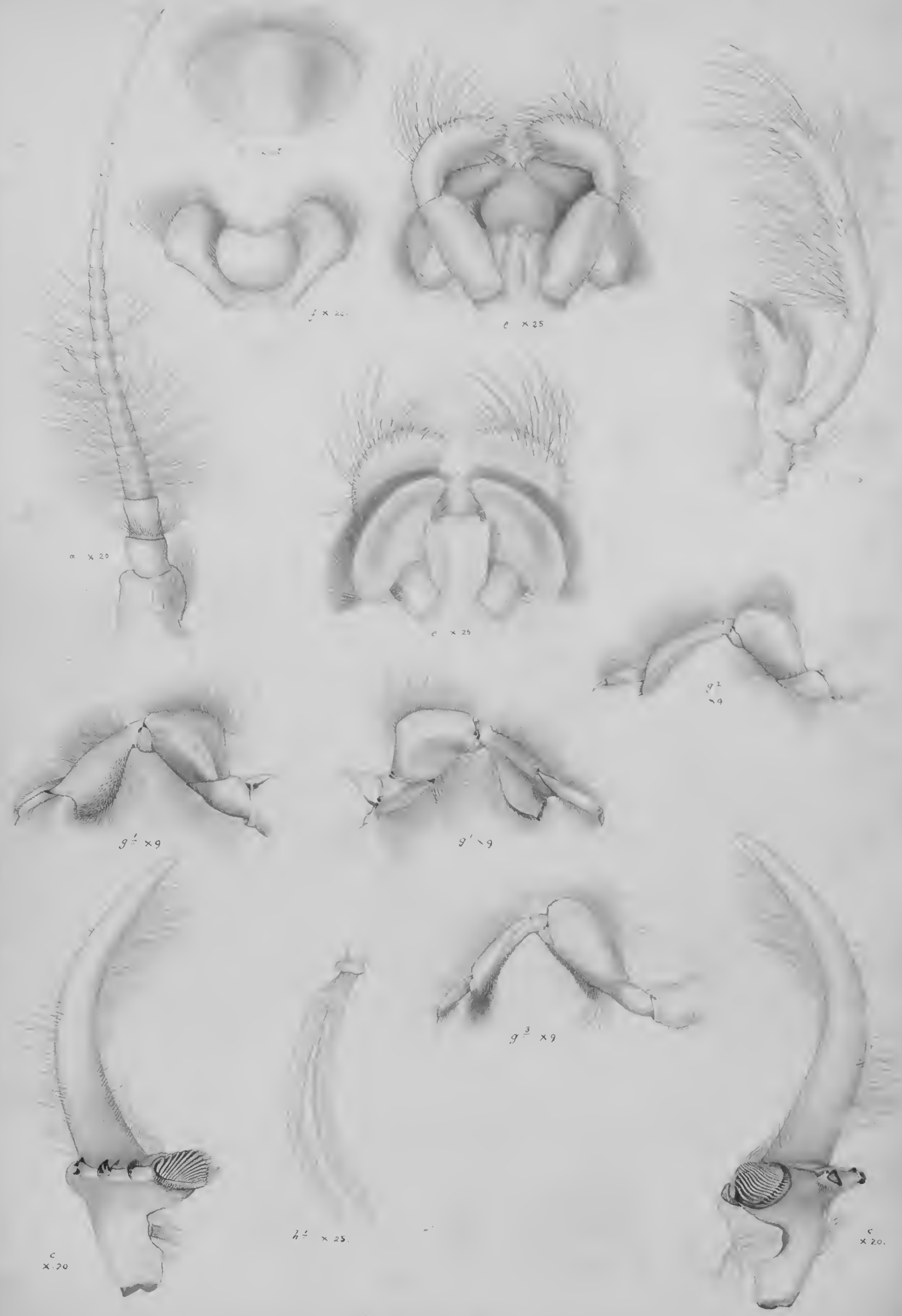




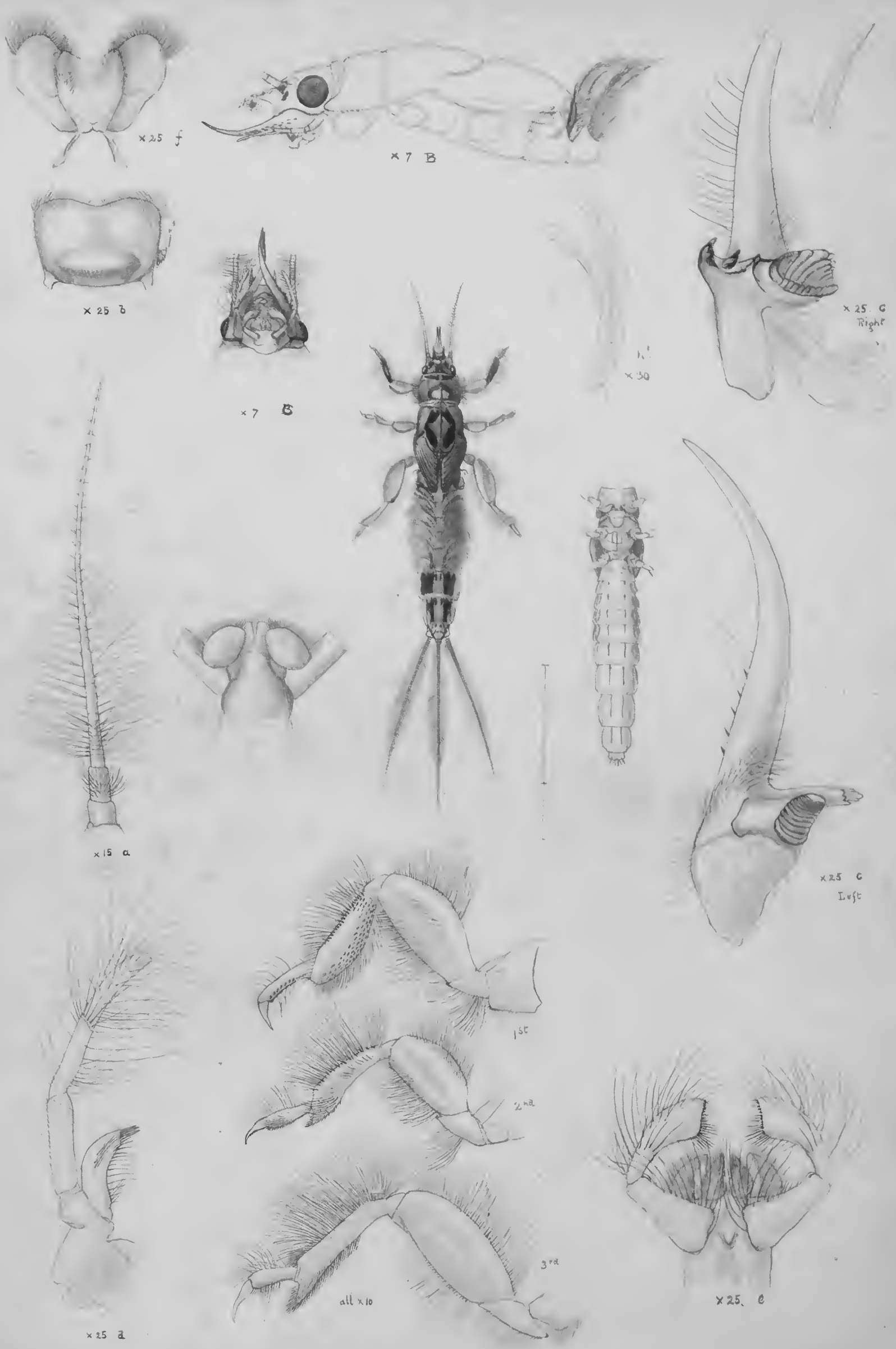




\section{Potamanthus Luteus}
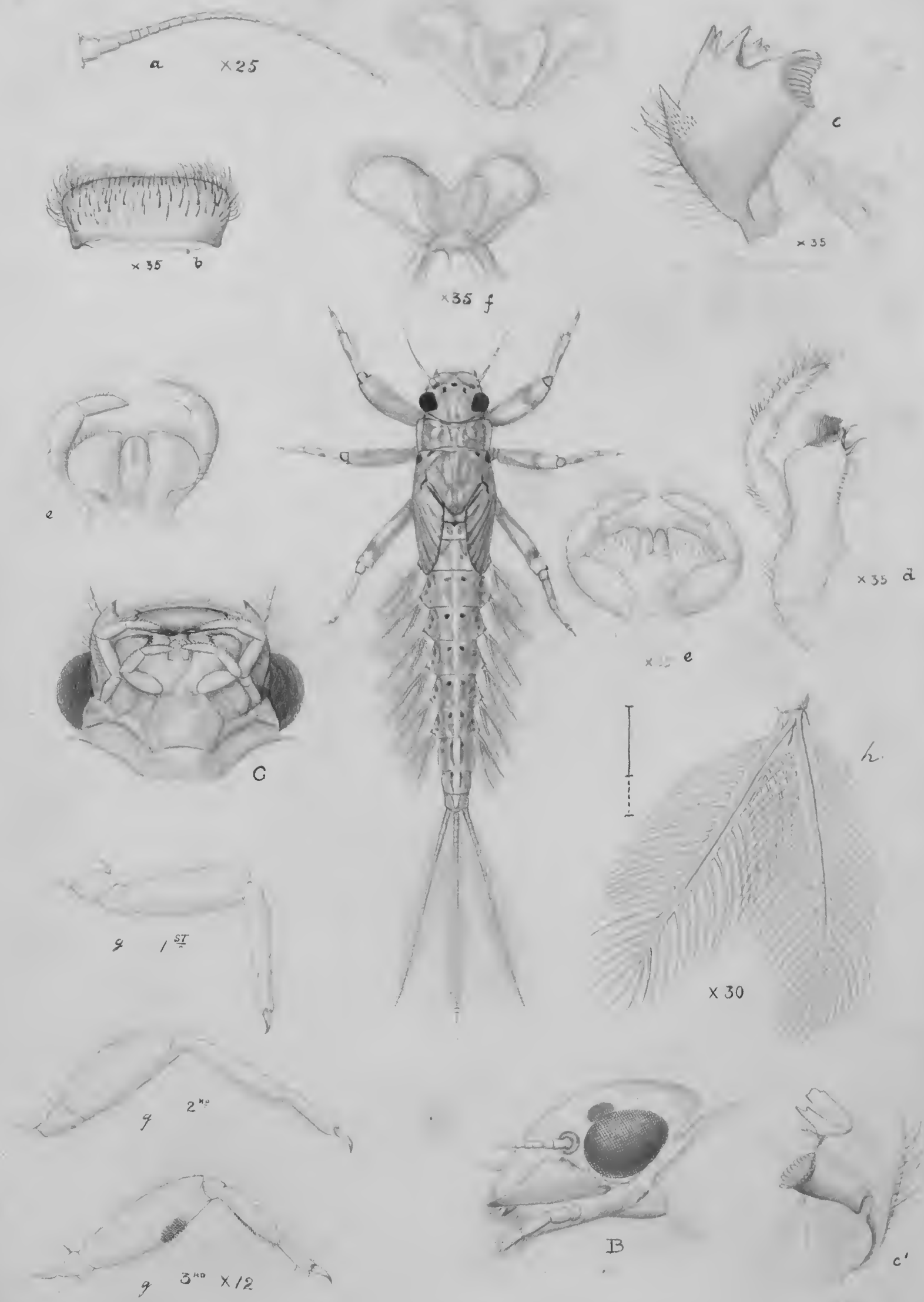

A. T. HOLLICK deL?

12.1878 

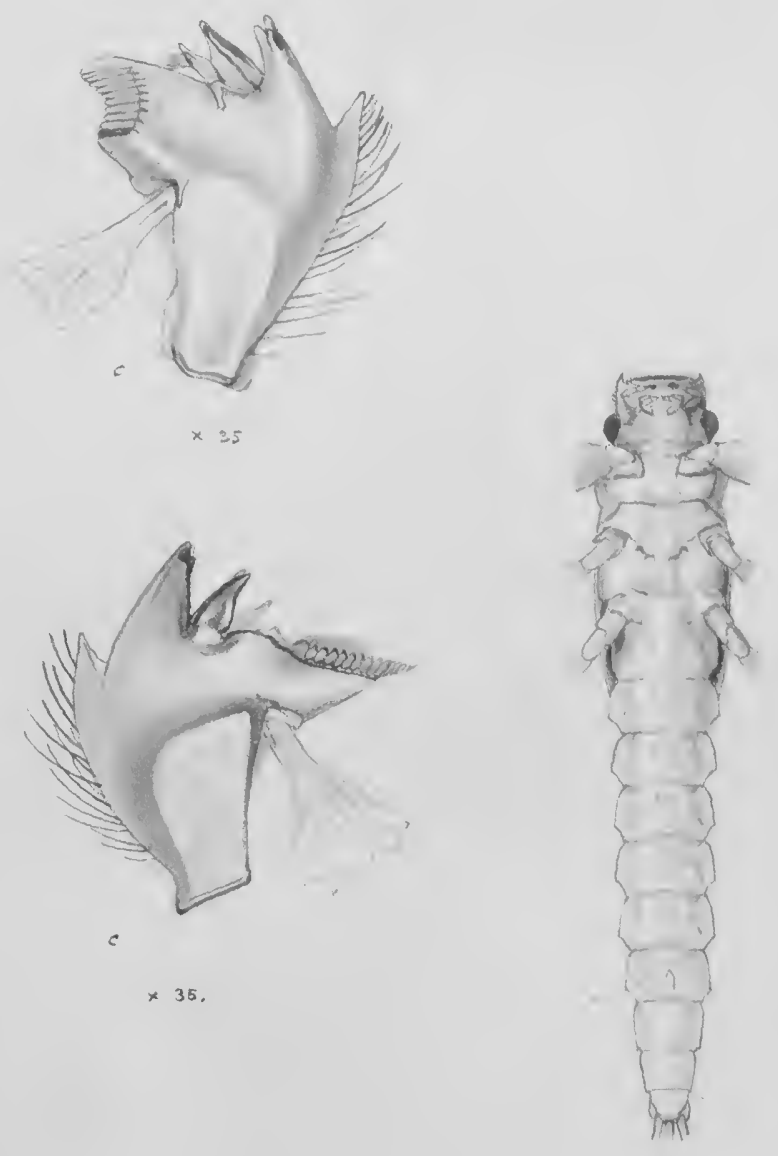


$$
11
$$



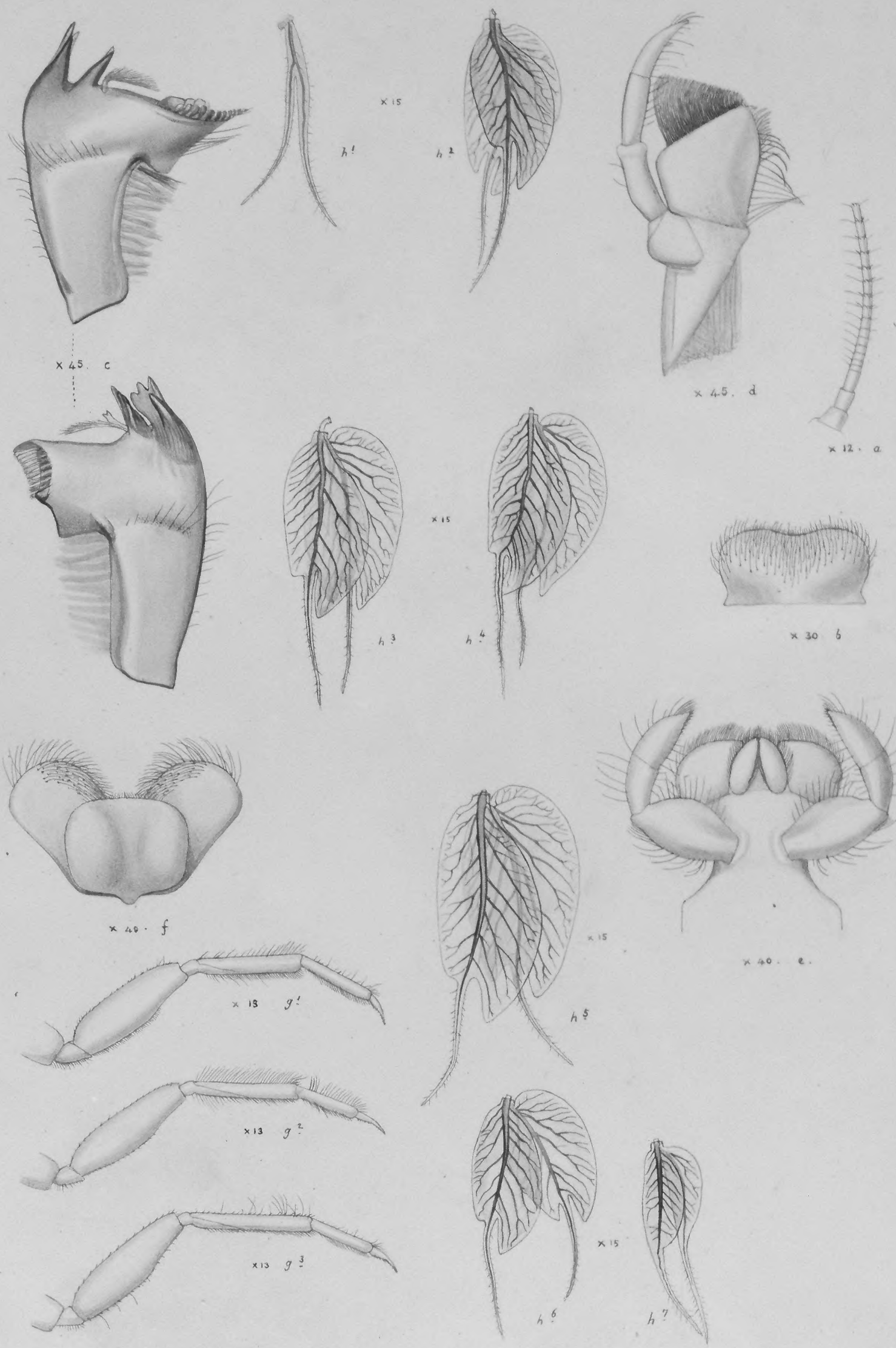

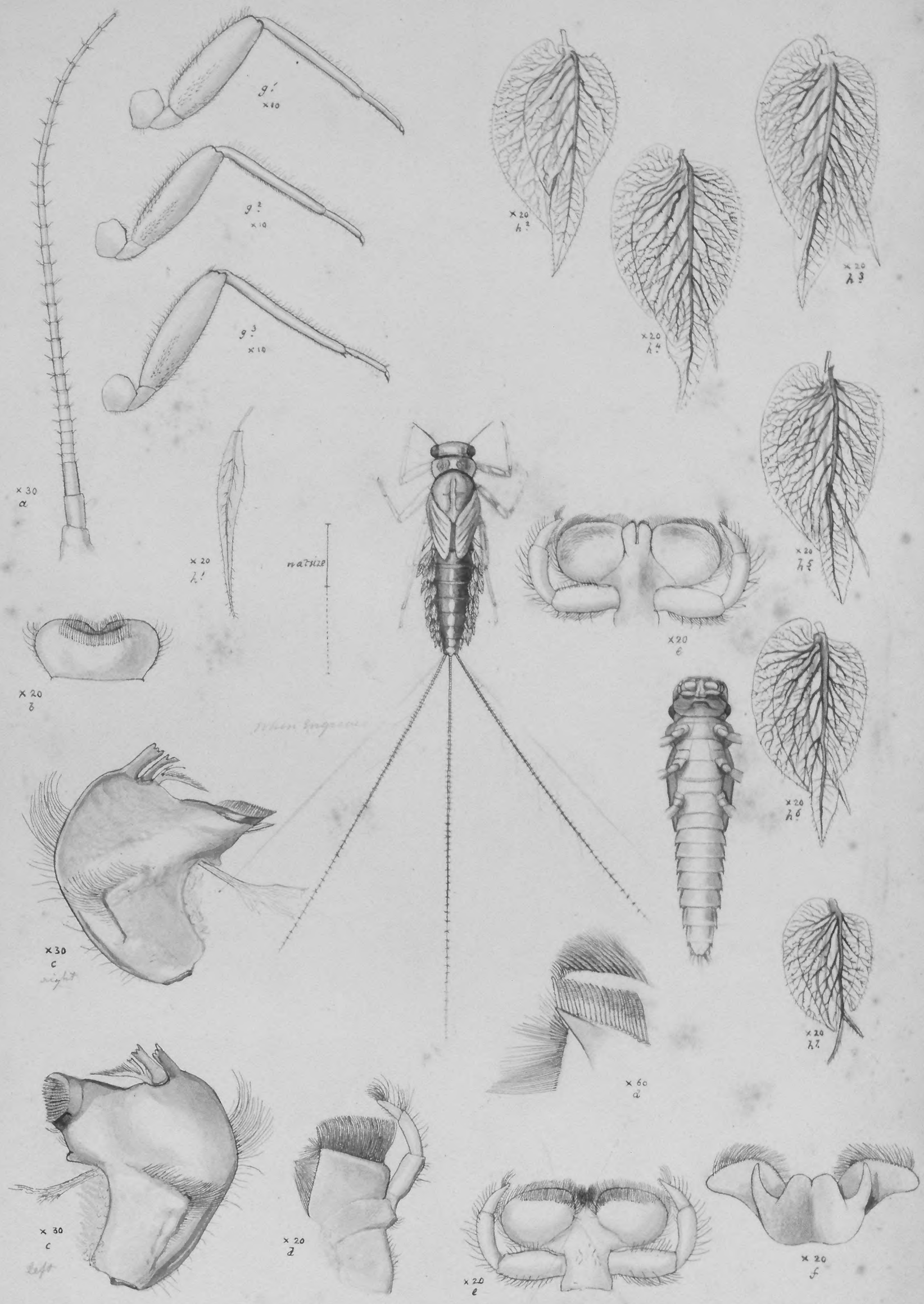

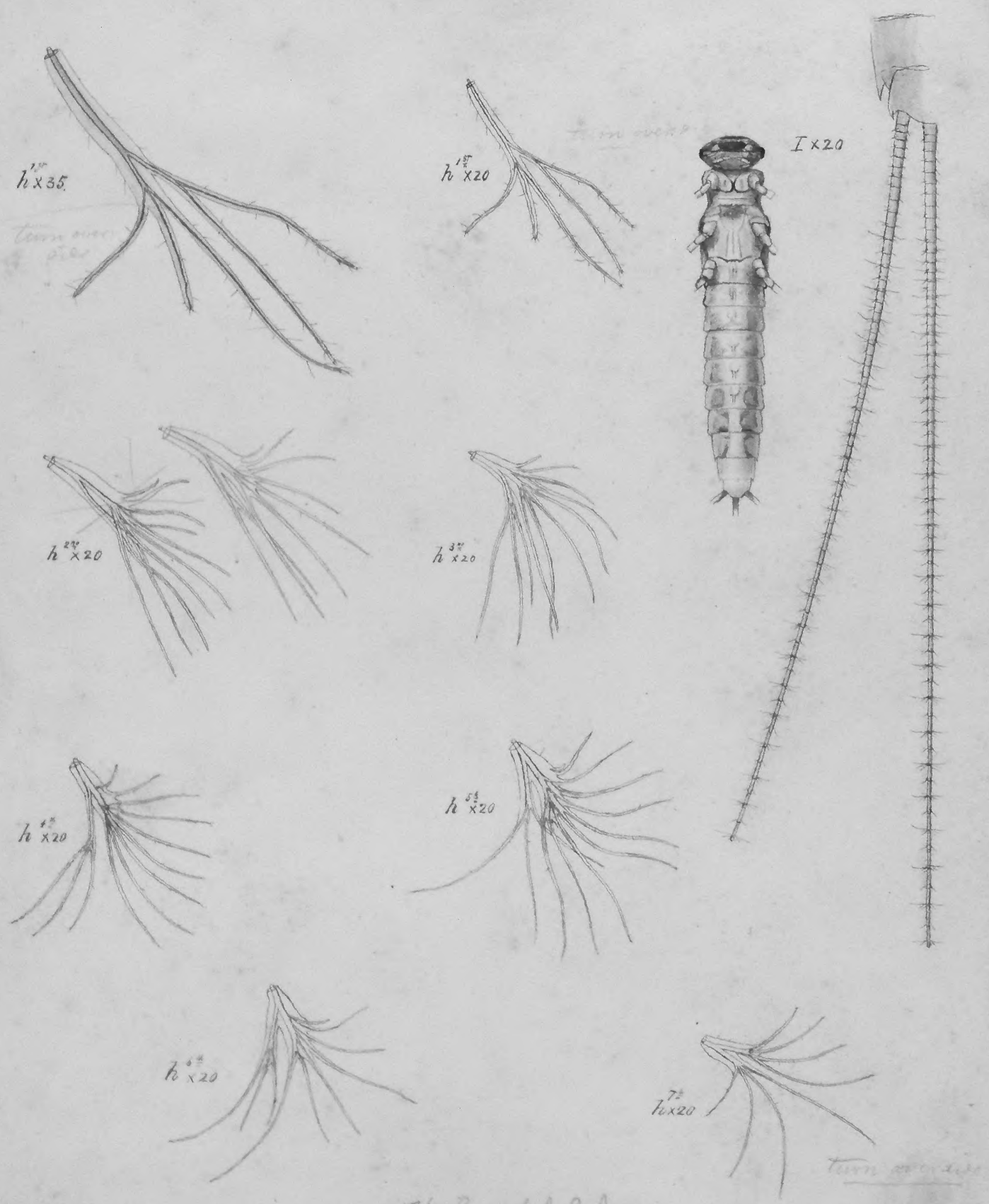

Eoptoputebia 